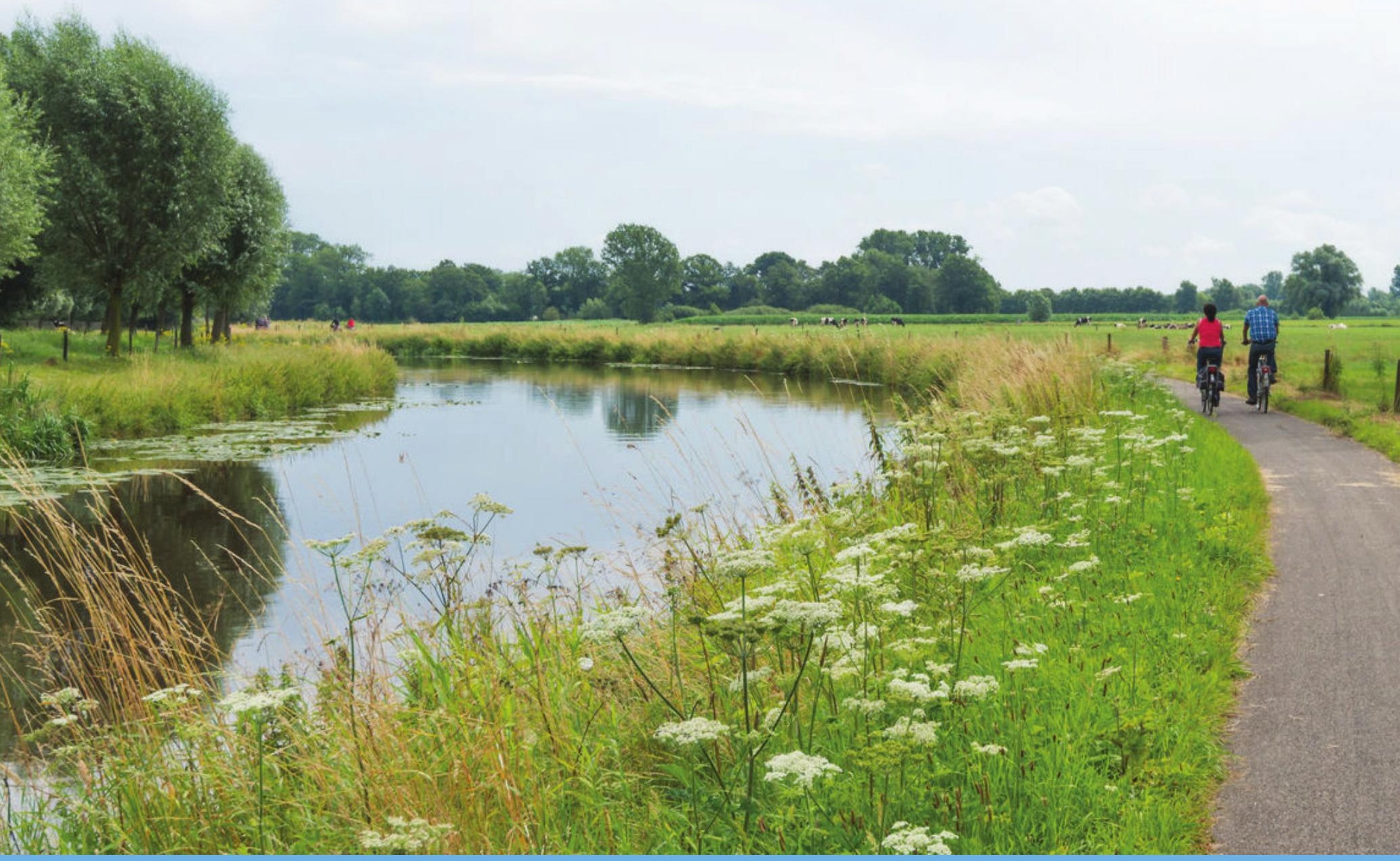

\title{
Evaluatie programma landbouwstructuurversterking Overijssel
}

F.G. Boonstra, J. van Os, H. Prins, P.J. Rijk, T.A. Vogelzang 



\section{Evaluatie programma landbouwstructuurversterking Overijssel}

F.G. Boonstra ${ }^{1}$, J. van $\mathrm{Os}^{1}$, H. Prins ${ }^{2}$, P.J. Rijk ${ }^{2}$, T.A. Vogelzang ${ }^{2}$

1 Wageningen Environmental Research

2 Wageningen Economic Research

Dit onderzoek is uitgevoerd door Wageningen Environmental Research in opdracht van de provincie Overijssel.

Wageningen Environmental Research

Wageningen, maart 2019

Gereviewd door:

Arjan Koomen, teamleider Regionale ontwikkeling en Ruimtegebruik

Akkoord voor publicatie:

Arjan Koomen, teamleider Regionale ontwikkeling en Ruimtegebruik

Rapport 2941

ISSN 1566-7197 
Boonstra, F.G, J. van Os, H. Prins, P.J. Rijk, T.A. Vogelzang, 2019. Evaluatie programma landbouwstructuurversterking Overijssel. Wageningen, Wageningen Environmental Research, Rapport 2941. 62 blz.; 2 fig.; 6 tab.; 0 ref.

Deze evaluatie van het programma landbouwstructuurversterking van de provincie Overijssel toont dat de provinciale ondersteuning van vrijwillige, planmatige kavelruil in de periode 2012-2018 heeft bijgedragen aan de toekomstbestendigheid van de landbouw in gebieden waar kavelruilruilprojecten zijn uitgevoerd. Door schaalvergroting verslechtert de verkaveling van landbouwbedrijven in Overijssel voortdurend. Door kavels te ruilen en samen te voegen, zijn de bedrijfshuiskavels en veldkavels van melkveehouderijbedrijven in gebieden met kavelruilprojecten vergroot en is de afstand tot de veldkavels verkleind. Op de deelnemende melkveebedrijven zijn de bewerkingskosten afgenomen met gemiddeld 27 euro per hectare per jaar. Slaagfactoren voor de kavelruilprojecten waren het goed kunnen inspelen op de wensen in het gebied en het bieden van maatwerk. Daarnaast was de aanwezigheid van voldoende ruilgrond bij aanvang van het project van doorslaggevend belang voor het succes van kavelruil. Voor de toekomstige opgaven in het landelijk gebied biedt een meer integrale inzet van het instrument kavelruil kansen.

Trefwoorden: landbouwstructuurversterking, kavelruil, Overijssel, evaluatie, Boetelerveld, Hof van Twente, Rheeze, Rheezerveen, Revolving Fund

Dit rapport is gratis te downloaden van https://doi.org/10.18174/473993 of op www.wur.nl/environmental-research (ga naar 'Wageningen Environmental Research' in de grijze balk onderaan). Wageningen Environmental Research verstrekt geen gedrukte exemplaren van rapporten.

2019 Wageningen Environmental Research (instituut binnen de rechtspersoon Stichting Wageningen Research), Postbus 47, 6700 AA Wageningen, T 0317480700 , www.wur.nl/environmental-research. Wageningen Environmental Research is onderdeel van Wageningen University \& Research.

- Overname, verveelvoudiging of openbaarmaking van deze uitgave is toegestaan mits met duidelijke bronvermelding.

- Overname, verveelvoudiging of openbaarmaking is niet toegestaan voor commerciële doeleinden en/of geldelijk gewin.

- Overname, verveelvoudiging of openbaarmaking is niet toegestaan voor die gedeelten van deze uitgave waarvan duidelijk is dat de auteursrechten liggen bij derden en/of zijn voorbehouden.

Wageningen Environmental Research aanvaardt geen aansprakelijkheid voor eventuele schade voortvloeiend uit het gebruik van de resultaten van dit onderzoek of de toepassing van de adviezen.

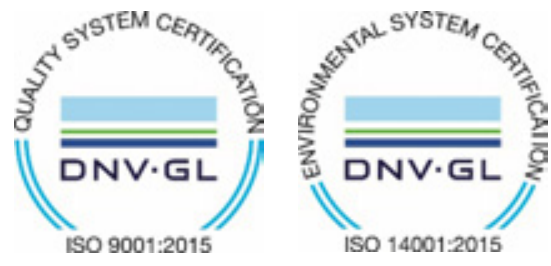

Wageningen Environmental Research werkt sinds 2003 met een ISO 9001 gecertificeerd kwaliteitsmanagementsysteem. In 2006 heeft Wageningen Environmental Research een milieuzorgsysteem geïmplementeerd, gecertificeerd volgens de norm ISO 14001.

Wageningen Environmental Research geeft via ISO 26000 invulling aan haar maatschappelijke verantwoordelijkheid.

Wageningen Environmental Research Rapport 2941 | ISSN 1566-7197

Foto omslag: Shutterstock 


\section{Inhoud}

$\begin{array}{ll}\text { Verantwoording } & 5\end{array}$

$\begin{array}{ll}\text { Samenvatting } & 7\end{array}$

$1 \quad$ Inleiding $r$

1.1 Aanleiding 11

1.2 Achtergrond $\quad 11$

1.3 Het instrument vrijwillige, planmatige kavelruil $\quad 12$

$\begin{array}{lll}1.4 & \text { Doel- en vraagstelling evaluatie } & 13\end{array}$

1.5 Aanpak evaluatie $\quad 13$

$\begin{array}{lll}1.6 & \text { Leeswijzer } & 14\end{array}$

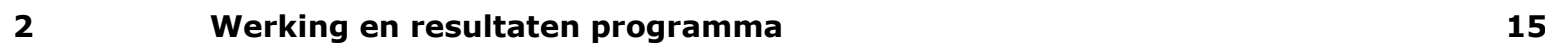

$2.1 \quad$ Inleiding $\quad 15$

$\begin{array}{lll}2.2 & \text { Input } & 15\end{array}$

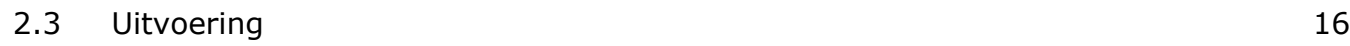

$\begin{array}{lll}2.4 & \text { Resultaten } & 18\end{array}$

$\begin{array}{lll}2.5 & \text { Slaag- en faalfactoren } & 21\end{array}$

2.6 Concluderend 24

$3 \quad$ Effecten kavelruil $\quad 26$

$\begin{array}{lll}3.1 & \text { Inleiding } & 26\end{array}$

3.2 Afbakening $\quad 26$

$\begin{array}{lll}3.3 & \text { Effecten op landbouwstructuur } & 27\end{array}$

$\begin{array}{lll}3.4 & \text { Bedrijfseconomische effecten } & 29\end{array}$

$\begin{array}{lll}3.5 & \text { Overige effecten } & 31\end{array}$

$\begin{array}{lll}3.6 & \text { Concluderend } & 31\end{array}$

$4 \quad$ Kavelruil in andere provincies $\quad 33$

4.1 Inleiding 33

4.2 Aanpak en ervaringen 33

$\begin{array}{lll}4.3 & \text { Concluderend } & 36\end{array}$

$5 \quad$ Kansen voor kavelruil bij toekomstige inrichtingsopgaven 37

$\begin{array}{lll}5.1 & \text { Inleiding } & 37\end{array}$

$\begin{array}{lll}5.2 & \text { Toekomstige inrichtingsopgaven } & 37\end{array}$

$\begin{array}{lll}5.3 & \text { De rol van kavelruil bij toekomstige inrichtingsopgaven } & 39\end{array}$

$\begin{array}{lll}5.4 & \text { Concluderend } & 41\end{array}$

$6 \quad$ Conclusies en aanbevelingen $\quad 42$

$\begin{array}{lll}6.1 & \text { Inleiding } & 42\end{array}$

$\begin{array}{lll}6.2 & \text { Resultaten en effecten } & 42\end{array}$

$\begin{array}{lll}6.3 & \text { Slaag- en faalfactoren } & 44\end{array}$

$\begin{array}{lll}6.4 & \text { Kavelruil in andere provincies } & 45\end{array}$

6.5 Toekomst programma en instrument kavelruil $\quad 45$

$\begin{array}{lll}\text { Bijlage } 1 & \text { Respondenten } & 48\end{array}$

Bijlage 2 Kavelruilprojecten 2012-2018 49

Bijlage $3 \quad$ Effecten landbouwstructuur $\quad 51$

$\begin{array}{lll}\text { Bijlage } 4 & \text { Bedrijfseconomische effecten } & 58\end{array}$ 



\section{Verantwoording}

Rapport: 2941

Projectnummer: 5200000666

Wageningen Environmental Research (WENR) hecht grote waarde aan de kwaliteit van onze eindproducten. Een review van de rapporten op wetenschappelijke kwaliteit door een referent maakt standaard onderdeel uit van ons kwaliteitsbeleid.

Akkoord Referent die het heeft beoordeeld,

functie: $\quad$ teamleider Regionale ontwikkeling en Ruimtegebruik

naam: Arjan Koomen

datum: $\quad 28-02-2019$

Akkoord teamleider voor de inhoud,

naam: Arjan Koomen

datum: $\quad 28-02-2019$ 


\section{Samenvatting}

De Provincie Overijssel investeerde in de periode 2012-2018 ruim 6 miljoen euro in landbouwstructuurversterking via het Programma Landbouwstuctuurversterking en POP 3. Deze middelen werden ingezet voor de ondersteuning van vrijwillige, planmatige kavelruilprojecten. Daarnaast zette de provincie het Revolving Fund in voor de aankoop van ruilgrond in kavelruilprojecten. Het Programma Landbouwstructuurversterking was gericht op het vergroten van de toekomstbestendigheid van de landbouw in Overijssel. Vrijwillige, planmatige kavelruil moest hiertoe bijdragen aan een optimaal vestigingsklimaat voor landbouwbedrijven in gebieden in de hele provincie met een slechte verkaveling. Waar nodig en haalbaar moest dit gebeuren in samenhang met andere provinciale opgaven, waaronder de realisatie van de Natura 2000-/PAS-opgave en de versterking van landschappelijke kwaliteit.

Nu het Programma Landbouwstructuurversterking is afgelopen, rest de vraag: hoe verder? Als input voor de besluitvorming hierover heeft Wageningen Research een evaluatie uitgevoerd van de uitvoering van het programma, de daarmee bereikte resultaten en effecten en de optredende slaagen faalfactoren. Hiertoe zijn onder meer interviews gehouden met betrokkenen bij de uitvoering van het programma, focusgroepen georganiseerd rond drie specifieke kavelruilprojecten en kwantitatieve analyses uitgevoerd. Bovendien is via een quickscan gekeken naar ervaringen van andere provincies met de ondersteuning van planmatige kavelruil.

\section{Aanpak uitvoering}

De uitvoering van het programma kende aanvankelijk twee sporen: een prestatieafspraak en programmafinanciering voor de stichting Coördinatie Kavelruil Overijssel (CKO) en de mogelijkheid van incidentele projectaanvragen van andere partijen. Van deze laatste mogelijkheid hebben vooral gemeenten gebruikgemaakt. Vanaf 2016 is ook POP3 jaarlijks opengesteld voor subsidieaanvragen van individuele kavelruilprojecten.

De aanpak van CKO en andere initiatiefnemers, zoals gemeenten en Stimuland, vertoont veel overeenkomsten. Alle partijen reageren op wensen en behoeften aan kavelruil uit het gebied, werken nauw samen met een lokale kavelruilcommissie en maken gebruik van de diensten van een kavelruilcoördinator. Op basis van de geïnventariseerde wensen van grondeigenaren werken de betrokken kavelruilcoördinatoren en kavelruilcommissies een of meerdere ruilplannen uit, waarover overeenstemming wordt gezocht met de betreffende grondeigenaren. Het proces wordt meestal binnen twee jaar afgesloten bij de notaris met het ondertekenen van een of meerdere ruilaktes door de deelnemende grondeigenaren.

De provincie heeft zelf geen initiatieven genomen voor planmatige kavelruil in gebieden waar zij inrichtingsopgaven heeft vanuit andere provinciale belangen, zoals Natura 2000. Planmatige kavelruilprocessen bieden volgens de provincie onvoldoende garantie op het volledig en tijdig realiseren van de ontwikkelopgave Natura 2000/PAS.

\section{Resultaten en effecten}

Het programma van de provincie en de aanpak van de initiatiefnemers en kavelruilcommissies heeft geresulteerd in vierentwintig projecten. Hiervan zijn twee projecten vroegtijdig gestopt, zeven afgerond en eind 2018 vijftien nog in uitvoering. In deze projecten is in totaal 1.053 hectare geruild. Hiermee is inmiddels 5.505 hectare landbouwstructuurversterking gerealiseerd. In totaal wordt er met de projecten 16.598 hectare landbouwstructuurversterking voorzien. Hiermee wordt in potentie ruimschoots voldaan aan de resultaatdoelstelling van 12.500 hectare landbouwstructuurversterking. Wel is er forse vertraging ontstaan in de uitvoering van het programma. De laatste projecten worden naar verwachting pas in 2021 afgerond.

Deze resultaten dragen bij aan de verbetering van de toekomstbestendigheid van de deelnemende bedrijven en de landbouwsector als geheel in de gebieden waar kavelruilprojecten zijn uitgevoerd. 
Vrijwillige, planmatige kavelruil draagt via de uitruil en omvorming van percelen bij aan verbetering van de verkavelingssituatie op gebiedsniveau. Zo heeft kavelruil in de projectgebieden tot een sterkere huisbedrijfskavelvergroting geleid dan in gebieden zonder ruilingen. Ook voor de vermindering van de kavelafstand tot de bedrijfslocaties hebben de ondersteunde kavelruilprojecten positieve effecten gehad. Melkveebedrijven in de gebieden waar ruilingen zijn uitgevoerd, realiseren een sterkere vergroting van de veldkavels dan in gebieden zonder kavelruil. Deze verbetering in de verkavelingssituatie betaalt zich uit in vermindering van de bewerkingskosten op bedrijfsniveau. Voor de deelnemende bedrijven komt dat neer op gemiddeld 1200 euro per jaar.

Vrijwillige, planmatige kavelruil kan ook positieve effecten hebben op de realisatie van andere maatschappelijke en publieke opgaven, zoals de Ontwikkelopgave Natura 2000/PAS, wateropgaven en landschapskwaliteit. Voor zover bekend, zijn de resultaten en effecten van het Programma Landbouwstructuurversterking op dit vlak beperkt. Er zijn in de afgeronde projecten hooguit enkele tientallen hectares vrijgespeeld voor natuurontwikkeling en wateropgaven. De provincie stuurt ook niet actief op bredere inzet van het instrument planmatige kavelruil. Het programma heeft een sectorale doelstelling en CKO en andere initiatiefnemers worden afgerekend op gerealiseerde hectares landbouwstructuurversterking, niet op meervoudig doelbereik. Het is dan ook niet ondenkbeeldig dat er door deze sectorale insteek kansen voor breder doelbereik zijn gemist.

\section{Slaag- en faalfactoren}

Belangrijke slaagfactoren voor de totstandkoming en uitvoering van kavelruilprojecten waren: het goed kunnen inspelen op de wensen in het gebied en het bieden van maatwerk. De gebiedskennis en onafhankelijkheid van de kavelruilcoördinator en de kavelruilcommissie waren hierbij cruciaal. Zij moeten het vertrouwen hebben van potentiële deelnemers om tot goede ruilvoorstellen te kunnen komen.

Daarnaast was de aanwezigheid van voldoende ruilgrond bij aanvang van het project van doorslaggevend belang voor het succes van kavelruil. Het Revolving Fund van de provincie is een nuttige faciliteit gebleken om grond die beschikbaar komt tijdens de projectperiode, aan te kunnen kopen en in te kunnen zetten als ruilgrond. Het Revolving Fund kent echter ook nadelen die de inzetbaarheid beperken. Zo schiet de snelheid van handelen van de provincie bij de inzet van het Revolving Fund soms tekort, met als risico dat de grond aan een andere partij wordt verkocht en niet meer kan worden ingezet in het kavelruilproject. Ook de koppeling van de aankooptitel aan een specifiek kavelruilproject beperkt de inzetbaarheid van het Revolving Fund, evenals het niet kunnen aankopen van bedrijfsgebouwen met middelen uit het fonds.

In de initiatieffase van projecten was de rol van een gebiedsmanager of -coördinator in de gemeenten die hierover beschikken belangrijk. Deze personen fungeren als loket voor diverse vragen, wensen en plannen van agrarische ondernemers en andere inwoners van het buitengebied. Ook de kansen voor kavelruil kan een gebiedscoördinator zodoende in een vroegtijdig stadium signaleren. Voordeel van deze werkwijze, boven die van CKO, is dat deze mensen op meer continue basis kansen voor kavelruil kunnen inventariseren in de gebieden waar ze actief zijn. Nadeel is dat niet alle Overijsselse gemeenten een dergelijke faciliteit financieren.

De programmafinanciering van CKO heeft geholpen om in gebieden waar de gemeente initiatieven voor kavelruil niet actief ondersteunt, toch kavelruilprojecten van de grond te tillen. Het programmabudget gaf CKO bovendien de mogelijkheid om de voordelen van kavelruil actief onder de aandacht te brengen in gebieden met een slechte of matige verkavelingssituatie.

Het niet goed betrekken van landschap in kavelruil is een potentiële faalfactor. Soms verdwijnen landschapselementen als kavels worden samengevoegd of worden kansen voor landschapsversterking niet benut. Dit kan het draagvlak voor kavelruil bij burgers en buitenlui ondermijnen.

\section{Evaringen andere provincies}

Net als Overijssel ondersteunen ook de provincies Gelderland, Utrecht, Noord-Holland en Zeeland kavelruil met subsidies en met inbreng van ruilgrond. Verschillen met de aanpak in Overijssel zijn onder meer het ontbreken van een meerjarig programma voor landbouwstructuurversterking en de 
meer integrale aanpak van kavelruilprojecten in Gelderland, Utrecht, Noord-Holland en Zeeland. De provincie Zeeland heeft verder een kavelruilbureau dat onderdeel is van de provinciale organisatie en een centrale kavelruilcommissie. In Utrecht is de uitvoering van door de provincie gesubsidieerde kavelruil belegd bij gebiedsorganisaties met een breder takenpakket. Noord-Holland, en tot voor kort ook Gelderland, kennen, net als in Overijssel, wel aparte stichtingen voor de ondersteuning van kavelruil, maar deze hebben een breder samengesteld bestuur en een bredere focus.

In deze provincies zijn goede ervaringen opgedaan met inzet van vrijwillige kavelruil voor bredere maatschappelijk opgaven. Naast landbouwstructuurversterking gaat het hierbij ook om natuur, recreatie, water en infrastructurele projecten. Initiatieven voor kavelruil komen behalve uit de landbouw ook van andere partijen als natuurorganisaties, waterschappen, gemeenten en de provincie zelf. Cruciale factoren voor succes zijn, net als in Overijssel, de onafhankelijke rol van de kavelruilcoördinator, het bieden van maatwerk en de beschikbaarheid van voldoende ruilgrond als smeermiddel. In Zeeland heeft het aankopen van ruilgrond, vooruitlopend op projecten, goed gewerkt.

\section{Aanbevelingen}

Voor de aanbevelingen over de toekomst van het programma en het instrument kavelruil zijn de volgende aspecten van belang:

- De noodzaak van doorgaande ondersteuning van kavelruil voor landbouwstructuurversterking.

- Mogelijke verbeteringen in de uitvoering van het programma.

- De rol die het Programma en het instrument kavelruil kunnen spelen bij toekomstige opgaven voor het landelijk gebied.

\section{Noodzaak doorgaande ondersteuning kavelruil}

Wat betreft de noodzaak van doorgaande ondersteuning is het van belang om te bepalen of er nog steeds een substantiële verkavelingsopgave is in Overijssel. De verkavelingskaart van het Kadaster toont dat het merendeel van de gebieden in Overijssel in 2015 matig tot redelijk verkaveld was en slechts een beperkt aantal gebieden goed tot uitstekend. De oorzaken van de niet optimale verkaveling zijn de doorgaande schaalvergroting in de landbouw. Agrarische bedrijven hebben behoefte aan meer grond, mede in het licht van de fosfaatwetgeving en nieuwe eisen ten aanzien van grondgebondenheid. Grond die op de markt komt omdat bedrijven stoppen, ligt echter niet altijd gunstig voor de nieuwe eigenaar of gebruiker. Soms lukt het bedrijven om percelen te verwerven die grenzen aan de huiskavel, maar meestal liggen de nieuwe percelen verder weg en wordt het bedrijfsoppervlak wel groter, maar de verkaveling slechter. Zolang de schaalvergroting doorzet, is verkaveling eigenlijk nooit 'op orde'. Om de politieke besluitvorming over de noodzaak van doorgaande ondersteuning van kavelruil te ondersteunen, verdient het aanbeveling het beeld van de verkavelingssituatie in Overijssel te actualiseren en een goede prognose te maken van de toekomstige ontwikkeling in de huisbedrijfskavelgrootte, het aantal veldkavels en de kavelafstand op gebiedsniveau (aanbeveling 1).

\section{Verbeterpunten uitvoering}

Ondanks het succes van het programma in termen van het aantal projecten en de gerealiseerde hectares landbouwstructuurversterking zijn er ook verbeterpunten voor de uitvoering. Zo zegt de Overijsselse methode voor berekening van de resultaten van het programma weinig over de daadwerkelijke versterking van de verkavelingssituatie en de bijdrage aan de toekomstbestendigheid van de sector, hetgeen een goede evaluatie bemoeilijkt. Het verdient daarom aanbeveling deze methode aan te passen op basis van de kengetallen die in de praktijk worden gebruikt, dat wil zeggen de gevolgen van kavelruil voor de huisbedrijfskavel, de kavelafstand en het aantal veldkavels van de betrokken ondernemers. Daarbij is het belangrijk niet alleen de effecten op bedrijfsniveau mee te nemen, maar ook te kijken naar de veranderingen in de verkavelingssituatie op gebiedsniveau (aanbeveling 2 ).

De resultaten en effecten van vrijwillige, planmatige kavelruilprojecten kunnen op gebiedsniveau nog worden versterkt door de inzet van het instrument kavelruil alleen te ondersteunen in gebieden met een aantoonbaar slechte of matige verkavelingssituatie én voldoende belangstelling voor deelname. Het verdient verder aanbeveling als provincie kritischer te zijn over de ondersteuning van projecten die in feite bestaan uit een serie losse kavelruilen (aanbeveling $\mathbf{3}$ ). 
In de uitvoering van de kavelruilen in Overijsel is een werkbare taakverdeling ontstaan tussen CKO, gemeenten en Stimuland. CKO ontvangt programmafinanciering en de andere initiatiefnemers projectfinanciering. Afgaande op de vergelijkbare resultaten die de verschillende organisaties boeken, is er geen duidelijke reden (meer) voor dit onderscheid in financiering. Voordeel van projectfinanciering is bovendien dat de initiatiefnemer pas een projectaanvraag indient als er voldoende zekerheid is over het behalen van resultaat. Indien de provincie wederom middelen beschikbaar stelt voor de ondersteuning van planmatige kavelruil verdient het aanbeveling de huidige financieringsstructuur, waarbij CKO programmafinanciering ontvangt en andere initiatiefnemers per project subsidie moeten aanvragen, te heroverwegen (aanbeveling 4).

Het Revolving Fund van de provincie is een nuttige faciliteit gebleken om grond die beschikbaar komt tijdens de projectperiode aan te kunnen kopen en in te kunnen zetten als ruilgrond, maar de inzetbaarheid kan nog wel worden vergroot. Het verdient aanbeveling het Revolving Fund voort te zetten en de mogelijkheden voor een bredere inzetbaarheid te verkennen, bijvoorbeeld voor het vooruitlopend op projecten reeds aankopen van ruilgrond (aanbeveling $\mathbf{5}$ ).

Rol programma en instrument kavelruil bij toekomstige opgaven

Richting 2050 komt een aantal nieuwe opgaven op het landelijk gebied van Overijssel af. Deze gaan over het opvangen van nieuwe ruimteclaims vanuit de klimaat-, landbouw- en energietransitie, het zorgvuldig omgaan met grondstoffen en productiefactoren, het terugdringen van milieubelastende emissies, het realiseren van ruimtelijke kwaliteit en het inzetten op sociale waarden. Voor de grondgebonden landbouw is het zo veel mogelijk sluiten van kringlopen een nieuwe uitdaging.

Indien de provincie Overijssel ervoor kiest deze opgaven in haar omgevingsbeleid in samenhang op te pakken, ligt het voortzetten van een overwegend sectoraal ingestoken programma voor kavelruil en een sectorale uitvoering niet voor de hand. Het instrument vrijwillige, planmatige kavelruil kan wel een nuttige functie blijven vervullen bij de nieuwe opgaven. De aanpak van deze opgaven zal immers vaak gepaard gaan met een ruimtelijke herordening van functies, waarvoor kavelruil kan worden ingezet. Het verdient dus aanbeveling het instrument kavelruil meer opgavegestuurd in te zetten. Dit kan door kavelruil beter in te bedden in het provinciale omgevingsbeleid en in integrale gebiedsprocessen, waarin de toekomstige opgaven van het landelijk gebied in samenhang worden uitgewerkt door gebiedspartijen (aanbeveling 6).

Bij de doorontwikkeling van het instrument kavelruil kan geleerd worden van de ervaringen met recente, meer integrale kavelruilprojecten rond het Boetelerveld, bij Losser en in Haaksbergen. Het verdient aanbeveling deze projecten te evalueren en de lessen te benutten voor de toekomstige inzet van het instrument kavelruil (aanbeveling 7).

Een meer opgavegestuurde aanpak brengt ook met zich mee dat de inzet van het instrument vrijwillige, planmatige kavelruil beter kan worden afgewogen tegen andere uitvoeringsinstrumenten van het omgevingsbeleid van de provincie en gezocht kan worden naar effectieve combinaties van kavelruil met andere instrumenten. Gezien de omvang en complexiteit van de nieuwe opgaven verdient ook wettelijke landinrichting, mogelijk in een vernieuwde vorm, betrokken te worden bij de instrumentenkeuze (aanbeveling 8).

Vrijwillige kavelruil kan minder vrijblijvend worden door te zorgen voor een bestuurlijk afsprakenkader op gebiedsniveau waarin doelen, spelregels en randvoorwaarden voor het kavelruilproces worden geborgd (aanbeveling 9).

Een meer integrale inzet van het instrument kavelruil kan ten slotte worden ondersteund door aanvragen voor subsidiëring vanuit gebieden te toetsen aan een brede set criteria, voortkomend uit het omgevingsbeleid en de integrale gebiedsopgaven. Naast landbouwstructuurversterking kan het hierbij gaan om de bijdrage aan landschappelijke, ecologische, cultuurhistorische en/of recreatieve betekenis van het landschap van het gebied en de betrokken percelen (aanbeveling 10). 


\section{$1 \quad$ Inleiding}

\section{$1.1 \quad$ Aanleiding}

Voor u ligt de rapportage van de evaluatie van het Programma Landbouwstructuurversterking van de provincie Overijssel. Aanleiding voor deze evaluatie is het aflopen van dit programma eind 2018. De provincie vraagt zich af hoe verder te gaan. Moet de gevolgde aanpak voor landbouwstructuurversterking worden voortgezet of zijn aanpassingen nodig? Een onafhankelijke evaluatie van het programma moet een bijdrage leveren aan de besluitvorming over de toekomst van het programma. Wageningen Research is gevraagd om deze evaluatie uit te voeren. De evaluatie moet inzicht geven in de werking van het programma, de resultaten en effecten en aanbevelingen geven voor een mogelijk vervolg.

\subsection{Achtergrond}

In november 2012 stelden Provinciale Staten (PS) van Overijssel het Investeringsvoorstel Herverkaveling 2012-2015 vast. Hiermee kwam 6 miljoen euro beschikbaar voor de realisatie van 12.500 hectare landbouwstructuurversterking in gebieden in heel Overijssel met een slechte verkaveling. Van dit bedrag was 4,5 miljoen euro beschikbaar voor 11.200 hectare planmatige, vrijwillige kavelruilen met een zogenaamde enkelvoudige doelstelling en werd 1,5 miljoen euro aangehouden voor 1.500 hectare landbouwstructuurversterking bij realisatie van de ontwikkelopgave EHS/Natura 2000 en de PAS. Deze laatste reservering kwam voort uit een PS-motie (Herverkaveling gronden rondom Natura 2000-gebieden van 19 september 2012). Deze riep op het verkavelingsinstrumentarium in te zetten om zo mogelijk de verkaveling van de blijvende bedrijven rondom Natura 2000-gebieden te verbeteren. Omdat de uitvoeringsduur van kavelruilprojecten gemiddeld drie jaar bedraagt, liep de initiële realisatieduur van het Programma Landbouwstructuurversterking tot en met 2018.

Met de ondersteuning van planmatige, vrijwillige kavelruil, wil de provincie bijdragen aan de toekomstbestendigheid van de landbouw in Overijssel. Kavelruil moet hiertoe bijdragen aan een optimaal vestigingsklimaat voor landbouwbedrijven in gebieden in de hele provincie met een slechte verkaveling. Waar nodig en haalbaar moet dit gebeuren in samenhang met andere provinciale opgaven, waaronder de realisatie van de Natura 2000-/PAS-opgave en de versterking van landschappelijke kwaliteit. ${ }^{1}$

Aanleiding voor het besluit van PS was de relatief ongunstige verkaveling van de Overijsselse landbouw vergeleken met andere provincies. Kavels zijn gemiddeld een halve hectare kleiner dan in de rest van Nederland. Van de ca. 210.000 hectare landbouwgrond in Overijssel had in 2009 ongeveer een derde een ongunstige verkaveling, gemeten in omvang van de huiskavel. Voor de ontwikkeling van een toekomstbestendige landbouw, gevormd door concurrerende en duurzame landbouwbedrijven, is volgens het besluit een goede verkaveling nodig. Deze goede verkaveling komt volgens de provincie echter niet vanzelf tot stand. Autonome ontwikkelingen als bedrijfsbeëindiging en schaalvergroting zorgen juist voor verdere verslechtering, omdat de grond die door bedrijfsbeëindiging beschikbaar komt vaak niet gunstig ligt voor schaal-vergrotende bedrijven. Er zou sprake zijn van een structurele onderhoudsopgave van ca. 10.000 hectare per jaar. ${ }^{2}$ De ervaring met het voorgaande programma (pMJP 2007-2013) leerde verder dat publieke ondersteuning van kavelruil succesvol is. In de in deze periode afgeronde projecten was de verkaveling volgens de provincie substantieel verbeterd. ${ }^{1}$

\footnotetext{
Statenvoorstel nr. PS/2012/870

2 Hemelaar (2012) Verbetering van de verkaveling van de grondgebonden landbouw in Overijssel. Verkenning van beleidsopties voor de periode 2012-2015 (met doorkijk naar daarna).
} 
Vanaf 2016 heeft de provincie ook via het Europese Plattelandsontwikkelingsprogramma (POP3) subsidie beschikbaar gesteld voor herverkaveling van landbouwbedrijven. Met de 'Regeling investeringen in infrastructuur voor de ontwikkeling, modernisering of aanpassing van landbouwbedrijven' uit POP3 wordt ingezet op de verbetering van de landbouwstructuur in Overijssel, met als doel de ontwikkeling van een duurzame en concurrerende landbouw in Overijssel. Naast verbetering van de bedrijfsefficiëntie kan de herstructurering van landbouwbedrijven volgens de provincie ook bijdragen aan de realisatie van internationale doelen rondom water, Programmatische Aanpak Stikstof (PAS), biodiversiteit, Natura 2000 en het in stand houden van het landschap. Met POP3 kwam er ongeveer 767.000 euro Europese financiering extra beschikbaar voor de ondersteuning van kavelruil. Dit bedrag werd gecofinancierd met resterende provinciale middelen uit het Programma Landbouwstructuurversterking.

\subsection{Het instrument vrijwillige, planmatige kavelruil}

Het beleidsinstrument vrijwillige kavelruil is, net als landinrichting, wettelijk verankerd in de Wet Inrichting Landelijk Gebied (WILG) en wordt daarin 'Ruilverkaveling bij overeenkomst' genoemd. Bij vrijwillige kavelruil komen drie of meer eigenaren op vrijwillige basis overeen om bepaalde, hun toebehorende zaken samen te voegen, de gegeven massa op bepaalde wijze te verkavelen en onder elkaar bij notariële akte te verdelen. Een belangrijke reden voor eigenaren om hiervoor te kiezen in plaats van voor gewone aan- en verkoop, is de vrijstelling van overdrachtsbelasting die geldt voor kavelruilen. Ook worden er, als de kavelruilen bijdragen aan provinciale beleidsdoelen, vaak provinciale subsidies verleend als vergoeding voor bijvoorbeeld proces- en ruilkosten en notaris- en kadasterkosten. In de meeste provincies zijn organisaties actief die kavelruilprocessen ondersteunen.

Doorgaans wordt in de praktijk onderscheid gemaakt tussen 'losse' kavelruil (tussen een beperkt aantal grondeigenaren) en planmatige kavelruil. Het onderscheid tussen beide vormen wordt bepaald door de aanwezigheid van een ruilplan voor een begrensd gebied en het zo veel mogelijk in één keer realiseren van de ruilen uit dit plan. Bij een losse kavelruil gaat het meestal om ruil tussen enkele grondeigenaren. Meestal is bij planmatige kavelruil ook sprake van meerdere doelen: naast landbouwstructuurversterking worden er ook natuur-, water- of recreatieopgaven mee gerealiseerd. Naast agrariërs of verpachters van agrarische gronden zijn bij de gesubsidieerde ruilen vooral stichtingen, Kadaster, gemeenten en/of waterschappen betrokken.

Vrijwillige, planmatige kavelruil wordt vaak gezien als alternatief voor wettelijke landinrichting ${ }^{3}$. Dit is echter maar ten dele het geval. Naast herindelen van grondgebruik via verkaveling kan wettelijke landinrichting namelijk ook gaan om de inrichting van landelijke gebieden door de uitvoering van werken, zoals het aanleggen van watergangen of kavelaanvaardingswerken, die erop gericht zijn om de toegedeelde kavels vergelijkbaar te maken met de ingebrachte kavels. In principe volgt de inrichting op het geven van bestemmingen in het kader van de ruimtelijke ordening. Wettelijke landinrichting is daarmee een uitvoeringsinstrument van de ruimtelijke ordening. De landinrichtingswetgeving bevat daarvoor juridisch uitvoeringsinstrumentarium, zoals allerlei gedoogplichten, de herverkaveling en financiële voorzieningen. Hieruit volgt onder meer dat grondeigenaren bij wettelijke landinrichtingsprocessen verplicht zijn om mee te werken aan het ruilplan. Dit is een belangrijk verschil met kavelruil, waarbij deelname vrijwillig is.

Vergeleken met kavelruilprojecten gaat het in wettelijke landinrichtingen meestal ook om grotere gebieden en wordt er geruild tussen meer eigenaren en grondeigenaren. Een ander belangrijk verschil is dat wettelijk landinrichting weinig meer wordt ingezet, terwijl vrijwillige, planmatige kavelruil nog wel veel voorkomt (zie ook hoofdstuk 4). Bij de afnemende inzet van wettelijke landinrichting speelt een belangrijke rol dat deze vorm van herverkaveling door veel bestuurders wordt geassocieerd met langdurige, ingewikkelde en dure processen. Verder schrikken zij vaak terug voor de dwingende

\footnotetext{
3 Het is gangbaar om met de toevoeging 'wettelijk' onderscheid te maken tussen landinrichting en vrijwillige kavelruil. We sluiten in dit rapport aan op dit taalgebruik en spreken dus van wettelijke landinrichting. Feitelijk is het aanduiden van het verschil tussen beide instrumenten op deze manier echter onjuist, want ook vrijwillige kavelruil heeft een wettelijke basis in de WILG en is dus ook 'wettelijk'.
} 
elementen van wettelijke landinrichting. Ook de perceptie van de aard van de inrichtingsopgaven speelt een rol: provincies vinden wettelijke landinrichting vaak een te zwaar instrument voor de huidige inrichtingsopgaven in het landelijk gebied. ${ }^{4}$

\subsection{Doel- en vraagstelling evaluatie}

Deze evaluatie richt zich op het beantwoorden van de volgende onderzoeksvragen:

1. In hoeverre hebben het Programma Landbouwstructuurversterking en de gehanteerde aanpak de gewenste resultaten en effecten opgeleverd in de provincie Overijssel?

2. Wat zijn succes- en faalfactoren in de uitvoering geweest?

3. Hoe geven andere provincies uitvoering aan landbouwstructuurversterking? Welke ervaringen hebben zij daarmee opgedaan?

4. Welke aanbevelingen zijn er voor een vervolg van het programma op basis van de antwoorden op bovenstaande vragen en toekomstige opgaven voor het landelijk gebied in Overijssel?

Bij de gewenste resultaten uit de eerste onderzoeksvraag gaat het met name om de gerealiseerde oppervlakte landbouwstructuurversterking. Met effecten wordt primair gedoeld op de bijdrage daarvan aan de toekomstbestendigheid van de landbouw. Daarnaast wil de provincie weten of de landbouwstructuurversterking ook heeft bijgedragen aan andere beleidsdoelen, zoals die voor natuur en water.

\subsection{Aanpak evaluatie}

In dit onderzoek gebruiken we het onderstaande evaluatiemodel, waarin de verschillende onderdelen uit de vraagstelling op logische wijze met elkaar in verband gebracht worden. Het model stelt ons in staat een samenhangend beeld te geven van de werking, resultaten en effecten van het Programma Landbouwstructuurversterking op de toekomstbestendigheid van de landbouw, ook in relatie tot andere doelen, en aanbevelingen te doen voor een mogelijk vervolg.
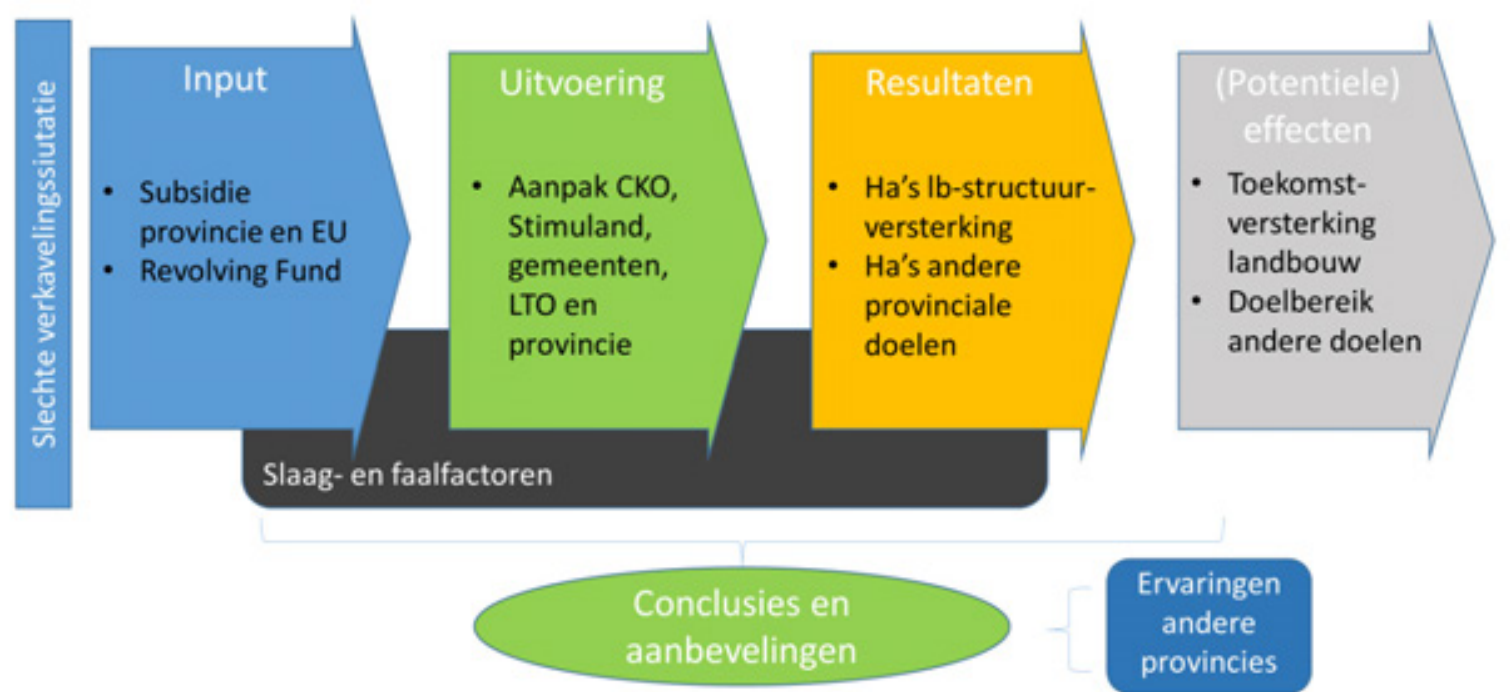

\section{Ervaringen

Figuur 1.1 Evaluatiemodel.

\footnotetext{
4 Boonstra, F.G., D.W. Bruil, R.J. Fontein en W. de Haas (2014), Evaluatie landinrichtingsinstrumentarium Wet inrichting landelijk gebied. Wageningen, Alterra.
} 
Voor het beantwoorden van de vraagstelling hebben we een mix van kwalitatieve en kwalitatieve onderzoeksmethoden ingezet. Onderdelen van deze aanpak waren de volgende:

1. Analyse Overijsselse aanpak en resultaten: via verkennende interviews met onder meer vertegenwoordigers van de provincie, CKO, LTO Noord, Stimuland en gemeenten en een deskstudy van beschikbare beleidsdocumenten en projectinformatie hebben we de Overijsselse aanpak voor landbouwstructuurversterking in beeld gebracht (zie bijlage 1 voor een overzicht van de respondenten). De resultaten op het vlak van landbouwstructuurversterking zijn door de initiatiefnemers zelf in beeld gebracht met behulp van de Overijsselse Methode Landbouwstructuurverbetering. Volgens die methode wordt na een herverkaveling per deelnemer het aantal toebedeelde hectares vergeleken met de totale bedrijfsgrootte na toedeling. Wanneer het aantal toebedeelde hectares $\times 10$ groter is dan de bedrijfsgrootte, staat de bedrijfsgrootte gelijk aan de gerealiseerde landbouwstructuurversterking voor die deelnemer. Wanneer het aantal toebedeelde hectares $\times 10$ kleiner is dan de bedrijfsgrootte, is de gerealiseerde landbouwstructuurversterking voor die deelnemer de toedeling $\times 10$. Het totale resultaat van een kavelruilproject is de som van de gerealiseerde landbouwstructuurversterking per deelnemer.

2. Analyse slaag- en faalfactoren: via focusgroepen met betrokkenen bij drie kavelruilprojecten in Overijssel zijn deze kavelruilprocessen en daarin optredende slaag- en faalfactoren onderzocht. De hiervoor geselecteerde kavelruilprojecten waren Rheeze-Rheezerveen, Hof van Twente 2013 en Boetelerveld. Deze selectie is tot stand komen door middel van spreiding op basis van de volgende kenmerken: regio, initiatiefnemer, integraal/sectoraal. Zie voor een overzicht van de deelnemers aan de focusgroepen bijlage 1 .

3. Kwantitatieve analyse-effecten: de bijdrage van het programma aan de toekomstbestendigheid van de landbouw in Overijssel is benaderd via (1) een analyse van gegevens uit het Geografisch Informatiesysteem Agrarische Bedrijven (GIAB) en de Basisregistratie Percelen (BRP) en (2) een modelmatige berekening van de bedrijfseconomische baten van uitgevoerde kavelruilprojecten. Hiervoor is gekozen, omdat de Overijsselse Methode voor het berekenen van landbouwstructuurversterking vooral is gericht op het kwantitatief monitoren van de voortgang en de resultaten van het programma en weinig zegt over de bijdrage aan de toekomstbestendigheid van de landbouw. Een uitgebreide verantwoording van deze methode staat in bijlage 3 en 4.

4. Quickscan kavelruil in andere provincies: de inzet van en ervaringen met het instrument kavelruil in andere provincies zijn geïnventariseerd aan de hand van provinciale beleidsdocumenten, websites en telefonische interviews met betrokkenen in de provincies Gelderland, Utrecht, NoordHolland en Zeeland (zie voor een overzicht van respondenten andere provincies bijlage 1).

5. Expert judgement rol kavelruil bij toekomstige opgaven landelijk gebied in Overijssel: Hiervoor is gebruikgemaakt van de trendverkenning uit het project Strategieontwikkeling duurzaam landelijk gebied Overijssel.

\subsection{Leeswijzer}

De opbouw van het verdere rapport is als volgt. In hoofdstuk 2 bespreken we de werking en resultaten van het Programma Landbouwstructuurversterking van de provincie Overijssel. Hoofdstuk 3 doet verslag van de bijdrage van afgeronde kavelruilprojecten aan de toekomstbestendigheid van de landbouw in Overijssel. In hoofdstuk 4 gaan we in op ervaringen met de inzet van het instrument kavelruil in de provincies Gelderland, Utrecht, Noord-Holland en Zeeland. Hoofdstuk 5 omvat een bespreking van de kansen voor kavelruil bij de aanpak van toekomstige inrichtingsopgaven in het landelijk gebied van Overijssel. In hoofdstuk 6 sluiten we af met conclusies en aanbevelingen voor de toekomst van het Programma Landbouwstructuurversterking. 


\section{$2 \quad$ Werking en resultaten programma}

\section{$2.1 \quad$ Inleiding}

Dit hoofdstuk gaat over de werking en resultaten van het Programma Landbouwstructuurversterking van de provincie Overijssel. We beschrijven en analyseren de input van het programma (par. 2.2), de aanpak van de uitvoering (par. 2.3), de voortgang en de resultaten (par. 2.4) en de door betrokkenen ervaren slaag- en faalfactoren in de uitvoering (par. 2.5). Dit alles illustreren we aan hand van een analyse van de kavelruilprocessen in Rheeze-Rheezerveen, Hof van Twente en Boetelerveld. We sluiten af met enkele concluderende opmerkingen (par. 2.6).

\subsection{Input}

De Provincie Overijssel investeerde met het Programma Landbouwstructuurversterking in de periode 2012-2015 6 miljoen euro in de ondersteuning van vrijwillige, planmatige kavelruil. Hiervan was 4,5 miljoen euro beschikbaar voor 11.200 hectare planmatige, vrijwillige kavelruil met enkelvoudige doelstelling en was oorspronkelijk 1,5 miljoen euro beschikbaar voor 1.500 hectare landbouwstructuurversterking bij realisatie van de Ontwikkelopgave EHS/Natura 2000 en de PAS. Begin 2015 heeft de provincie deze laatste 1,5 miljoen euro overgeheveld naar het Programma Ontwikkelopgave Natura 2000/PAS, omdat daar vooral aan integrale opgaven wordt gewerkt. ${ }^{5}$ Uit dat budget is vooralsnog bijgedragen aan één kavelruilproject (Boetelerveld).

In de periode 2016-2018 heeft de provincie ongeveer 767.000 euro Europese POP3-middelen besteed aan de ondersteuning van kavelruilprojecten. De resterende provinciale middelen uit het programma Landbouwstructuurversterking zijn hierbij ingezet als cofinanciering. Initiatiefnemers konden gedurende de openstellingsperiodes van POP3 in 2016, 2017 en 2018 aanvragen indienen. In POP3 zijn ook mogelijkheden voor subsidiering van kavelaanvaardingswerken opgenomen.

Daarnaast heeft de provincie ook een Revolving Fund opgezet voor het aankopen van ruilgrond voor landbouwstructuurversterking. Om hiervan gebruik te maken, moet de initiatiefnemer van kavelruil bij aanvang van het project een aanvraag indienen voor een aankooptitel voor een bepaalde periode. Meestal gaat het om zo'n 15 hectare grond die gedurende drie jaar kan worden ingezet voor een specifiek project. De aangekochte grond kan één of meerdere malen worden ingebracht in kavelruilen en wordt uiteindelijk afgestoten, waarna het aankoopbedrag terugvloeit naar het Revolving Fund. Het initiatief voor aankopen ligt in de praktijk bij de betrokken kavelruilcommissie. Die beoordeelt of de grond geschikt is als ruilgrond in de kavelruil. Om gebruik te maken van het Revolving Fund moet de grond worden getaxeerd. Er zit 22 miljoen euro in het Revolving Fund.

Ook heeft de provincie een groot aantal gronden in eigendom die in het verleden zijn aangekocht voor de realisatie van de EHS, maar die buiten de begrenzing van deze EHS liggen. Deze gronden zijn in twee categorieën ingedeeld: ruilgronden en restgronden. De ruilgronden kunnen worden ingezet voor ruiling ten behoeve van het Natuurnetwerk. De restgronden worden verkocht, mits ze niet ingezet kunnen worden als ruilgrond in bijvoorbeeld kavelruilprojecten. ${ }^{6}$

\footnotetext{
5 GS voorstel 2015/0157670

${ }^{6}$ Provincie Overijssel (2014) Nota Grondbeleid 2015
} 


\section{$2.3 \quad$ Uitvoering}

\section{Rol en aanpak provincie}

Belangrijke uitgangspunten voor het provinciale Programma Landbouwstructuurversterking zijn dat de agrarische sector zelf aan zet is om initiatieven voor kavelruil te nemen en dat er geruild wordt op basis van vrijwilligheid. De provincie heeft hierbij een overwegend faciliterende rol. In die rol subsidieert ze alleen de ondersteuning van planmatige, vrijwillige kavelruilen en dus niet van losse kavelruilen. Het subsidie is $80 \%$; de overige $20 \%$ moet van deelnemende grondeigenaren komen. In de praktijk is de eigen bijdrage van deelnemers ca. 300-600 euro per hectare.

De provincie heeft vanuit haar faciliterende rol vanaf 2012 tot en met 2015 beschikkingen verleend aan de stichting Coördinatie Kavelruil Overijssel (CKO) voor het uitvoeren van een programma van projecten en aan verschillende gemeenten en Stimuland voor het uitvoeren van individuele projecten. CKO heeft een prestatieafspraak met de provincie om 8000 hectare landbouwgrond met verbeterde structuur te realiseren in de periode 2012-2018 en kreeg hiervoor 2,8 miljoen aan programmafinanciering van de provincie. De gemeenten en Stimuland dienden voor elk project aparte projectvoorstellen in. Subsidiabele kosten betreffen de voorbereiding van de kavelruil, de uitvoering (het opstellen van ruilplannen) en de administratieve afhandeling (notaris- en kadasterkosten). Voor kavelaanvaardingswerken, zoals het aanleggen van dammen of drainage, geldt een lager subsidie van $40 \%$, de overige $60 \%$ moet door de deelnemers worden betaald.

Sinds de openstelling van POP3 voor kavelruilprojecten en de uitputting van de programmafinanciering van CKO dienden zowel gemeenten, Stimuland als CKO aparte POP3-aanvragen in voor kavelruilprojecten. In de POP3-regeling worden notaris- en kadasterkosten niet gesubsidieerd. Hierdoor ontstaat volgens de provincie indirect een bijdrage van de deelnemers van minimaal $20 \%$ van de kosten. ${ }^{7}$ Ook wordt in de POP3-regeling geen onderscheid gemaakt tussen subsidiabele, planmatige en niet-subsidiabele losse kavelruilen, zoals dat wel gebeurt in het programma Landbouwstructuurversterking. Om in aanmerking te komen voor POP3-subsidie geldt er wel een ondergrens in hectares.

In kavelruilen heeft de provincie Overijssel soms ook een deelnemende private rol als grondeigenaar. De aan de kavelruil voorafgaande verwerving van ruilgronden (als inbrengpositie in de kavelruil) behoort eveneens tot de rol van de provincie als privaat handelende partij. Deze rol wordt in de praktijk ingevuld door het Team Grondzaken van de provincie.

Naast de genoemde faciliterende rol en de rol als grondeigenaar kan de provincie bij kavelruilen ook een initiërende rol hebben. Dit is volgens de oorspronkelijke Statennotitie aan de orde in gebieden waar de provincie inrichtingsopgaven heeft vanuit andere provinciale belangen, zoals Natura 2000. Dan is de provincie ook initiatiefnemer en opdrachtgever van kavelruilprojecten. ${ }^{8}$ Aan deze rol is gedurende de uitvoeringsperiode van het programma door de provincie geen invulling gegeven. Om grond beschikbaar te krijgen voor de inrichtingsmaatregelen in de Natura 2000-gebieden, geeft de provincie er inmiddels de voorkeur aan om privaatrechtelijke afspraken te maken met de betreffende eigenaren uit het uitwerkingsgebied. Zelfrealisatie, waarbij de grondeigenaren de gewenste maatregelen zelf realiseren, is de voorkeursoptie, maar het kan ook gaan om minnelijke verwerving en uiteindelijk onteigening. Kavelruil komt in beeld als agrariërs als compensatie voor zelfrealisatie geen geld willen, maar grond. Hiervoor koopt de provincie dan ruilgrond aan buiten de begrenzing van de Natura 2000-gebieden, die kan worden geruild met agrariërs binnen de begrenzing. Dit zijn echter meestal losse kavelruilen of reguliere aan- en verkooptransacties die buiten de scope van het programma vallen. ${ }^{7}$

Inmiddels is er wel een aantal planmatige kavelruilprojecten gestart die naast landbouwstructuurversterking ook bij kunnen dragen aan (het draagvlak voor) de Natura 2000-/PASontwikkelopgave in de betreffende gebieden. Het initiatief voor deze projecten ligt echter niet bij de provincie, maar in het geval van het Boetelerveld bij LTO Salland en de gemeente Raalte en bij de projecten in Losser bij LTO Noordoost Twente en CKO. Ook in het CKO-project Haaksbergen wordt

\footnotetext{
7 Beantwoording Statenvragen, 2017/0275893

8 Statenvoorstel nr. PS/2012/870
} 
'een stukje van de oplossing' voor de ontwikkelopgave Natura 2000/PAS gezocht. Deze

kavelruilprojecten vinden plaats in nauwe afstemming met de Natura 2000-projecten en worden financieel ondersteund door de provincie.

\section{Rol en aanpak initiatiefnemers}

Formeel worden CKO, gemeenten en Stimuland als initiatiefnemer voor kavelruilen gezien omdat zij subsidie aanvragen bij de provincie, maar in de praktijk komt het initiatief voor kavelruil meestal van plaatselijke LTO-afdelingen of groepen boeren, soms in samenspraak met een gemeentelijke gebiedsmanager. Naar aanleiding van de kansen die zij zien voor kavelruil vragen zij dan CKO, de gemeente of Stimuland een kavelruilproject te starten. CKO en gemeenten maken verder vaak gebruik van de diensten van projectmanagers en/of kavelruilcoördinatoren of -begeleiders die in dienst zijn van andere organisaties zoals LTO, Kadaster en Stimuland of als zelfstandige opereren. De meeste kavelruilcoördinatoren zijn voormalige agrariërs die uit de streek komen en daar bekendheid hebben. Zij opereren meestal als vertrouwenspersoon richting de deelnemers aan de kavelruil.

De keuze voor CKO of gemeenten als aanvragende partij hangt samen met bestaande relaties en voorkeuren van lokale LTO-bestuurders. Daarnaast speelt een rol dat niet alle Overijsselse gemeenten een plattelandsontwikkelingsprogramma en gebiedsmanagers- of coördinatoren hebben waarmee ze kavelruil kunnen ondersteunen. Dat betekent in de praktijk dat CKO vooral actief is in gebieden waar de gemeente zelf geen initiatief neemt en wel behoefte is aan kavelruil.

De Stichting CKO is in 2008 opgericht door LTO Noord, het Kadaster en de toenmalig DLG om in zogenaamde witte gebieden in Overijssel kavelruilprojecten op te starten en te begeleiden, gericht op verbetering van de landbouwstructuur. CKO heeft een bestuur met een onafhankelijke voorzitter en twee agrarische leden die worden voorgedragen door LTO Noord. De provincie, het Kadaster en LTO Noord zijn adviseur. CKO wordt secretarieel ondersteund door het Kadaster.

CKO gaat actief 'de boer op' om LTO-bestuurders, gemeenten, waterschappen en erfbetreders over de voordelen van structuurverbetering via kavelruil te informeren. CKO ondersteunt verder concrete initiatieven tot kavelruilen en begeleidt het vrijwillige, planmatige kavelruiltraject tot en met de daadwerkelijke ruiling. Fasen in dit proces zijn:

- Initiatieffase: in deze fase voert het Kadaster meestal een quickscan uit van de verkavelingssituatie in het gebied op basis van de beschikbare administratieve gegevens en worden ook eventuele andere doelen voor het gebied geïnventariseerd. Ook wordt een voorlichtingsbijeenkomst georganiseerd voor de streek. Grondeigenaren met meer dan 4 hectare grond in eigendom worden uitgenodigd zich aan te melden. Ook stelt CKO in deze fase de kavelruilcommissie samen.

- Voorbereidingsfase: in deze fase vindt een startbijeenkomst plaats voor grondeigenaren die zich naar aanleiding van de voorlichtingsbijeenkomst hebben aangemeld, gevolgd door zogenaamde wenszittingen. Tijdens deze gesprekken worden de bereidheid tot ruilen en de wensen wat betreft over- en onderbedeling besproken en kunnen deelnemers aangeven welke percelen men wil inbrengen aan de hand van de eigendom/gebruikerskaart van de percelen van de deelnemers in de groep. Per deelnemer wordt vermeld voor welk perceel of welke percelen belangstelling is om te ruilen. Cruciale partijen die zich niet hebben aangemeld, kunnen in deze fase door de commissieleden worden benaderd om de wenszitting te bezoeken. Naast de aanmelders worden ook relevante instanties zoals provincie, gemeenten, waterschappen en terreinbeheerders gevraagd om hun wensen en plannen in het gebied duidelijk te maken. Op grond van de resultaten van de wenszittingen wordt besloten of de kavelruil wordt voortgezet.

- Uitvoeringsfase: nadat duidelijk is wat ieders wensen zijn, begint de commissie met het opstellen van een of meerdere conceptruilplannen. Het opbouwen van meerdere ruilplannen geeft de mogelijkheid een minder succesvol lijkende ruiling in de loop van het proces te laten vervallen en andere ruilplannen wel door te laten gaan. De deelruilplannen worden door de kavelruilcoördinator aan de keukentafel besproken met de belanghebbenden. Wijzigingen die hieruit voortkomen, worden besproken met de commissie. Soms ook ontwikkelen de deelnemers het ruilplan gezamenlijk in groepsbijeenkomsten. Zodra overeenstemming bereikt is met een belanghebbende wordt een intentieverklaring ondertekend. Indien voor één ruil alle benodigde intentieovereenkomsten zijn getekend, is de ruil rond. 
- Afrondingsfase: in deze fase vindt de administratieve afhandeling van het project plaats. Het gaat daarbij om achtereenvolgens de ondertekening van de kavelruilovereenkomst, de aktepassering bij de notaris, de verrekening van de kosten met de ondernemers (eindafrekening) en de formele afsluiting van het kavelruilproject. Het is mogelijk dat deze fase per deelruilplan doorlopen wordt. Indien er kavelaanvaardingswerken worden uitgevoerd, vinden die in deze periode plaats.

De werkwijze bij initiatieven van gemeenten en Stimuland is in grote lijnen vergelijkbaar met die van CKO. Ook gemeenten en Stimuland hanteren het uitgangspunt dat het initiatief uit het gebied zelf moet komen. Een belangrijk verschil is wel de rol van de gebiedsmanager of -coördinator. Gemeenten zoals Raalte en Hof van Twente maken gebruik van de diensten van een gebiedscoördinator, die regelmatig bij de agrarische ondernemers en andere inwoners van het buitengebied over de vloer komt en door hen benaderd kan worden met vragen, wensen of plannen op uiteenlopend terrein. Ook kansen voor kavelruil kan de gebiedscoördinator zodoende in een vroeg stadium signaleren. Deze activiteiten vormen dan ook de basis voor het ontstaan van diverse kavelruilinitiatieven in de genoemde gemeenten. De projectmanagers en/of kavelruilcoördinatoren van CKO zijn niet continu in de gebieden aanwezig en richten zich uitsluitend op kavelruil.

Gemeenten vragen vervolgens subsidie aan bij de provincie voor het betreffende kavelruilproject en besteden de uitvoering ervan uit aan projectmanagers en gebieds- of kavelruilcoördinatoren van bureaus als Stimuland en Pratensis en/of zzp'ers. Deze projectmanagers en kavelruilcoördinatoren werken meestal onder regie van de voor de duur van het project ingestelde kavelruilcommissies. De gemeente Hof van Twente heeft inmiddels één kavelruilcommissie die alle kavelruilprojecten in de gemeente aanstuurt en ook nieuwe projecten initieert. Dit leidt in de praktijk tot een continu proces van verkaveling, waarin men achtereenvolgens verschillende deelgebieden in de gemeente onder handen neemt en vooral kleinere ruilen realiseert. De gemeente staat in deze constructie garant voor (een deel van de) kosten die in de initiatieffase worden gemaakt en draagt soms ook bij vanuit de post gebiedsmanagement. Als de kavelruil geen succes wordt, is de gemeente dat geld kwijt. Stimuland neemt naast het uitvoeren van projecten voor gemeenten ook zelf initiatieven en fungeert dan als projectaanvrager. Zie voor een overzicht van de projecten en bijbehorende initiatiefnemers bijlage 2 .

Meestal werken de betrokken kavelruilcoördinatoren en kavelruilcommissies aan meerdere ruilplannen die elkaar opvolgen in de tijd. Voordeel hiervan is volgens betrokkenen dat de tijd tussen het ondertekenen van de intentieverklaring en het passeren van de akte bij de notaris zo kort mogelijk gehouden kan worden en grondeigenaren snel weten waar ze aan toe zijn. Bovendien gaat bij het terugtrekken van één partij niet de ruiling over het gehele gebied onderuit. Deze voordelen wegen volgens de betrokkenen op tegen de extra notariskosten die gemaakt moeten worden voor het passeren van meerdere aktes. Dit roept wel de vraag op wat hier nog planmatig aan is, omdat immers niet gewerkt wordt één groot ruilplan. Volgens een betrokkene is het planmatige in deze opzet het feit dat het ene deelruilplan niet ten koste gaat van een ander deelruilplan en dat er sprake is van een afgebakend gebied en uitvoeringsperiode.

\subsection{Resultaten}

In de uitvoeringsperiode van het Programma Landbouwstructuurversterking zijn in totaal 24 projecten $^{9}$ gestart. Hiervan zijn twee projecten vroegtijdig gestopt, zeven afgerond en vijftien nog in uitvoering (zie voor een overzicht van de projectkenmerken bijlage 2 en figuur 2.1). Twaalf projectinitiatieven zijn afkomstig van CKO, zeven van gemeenten (Hof van Twente, Raalte, Twenterand en Deventer) en vijf van Stimuland.

In deze projecten is in totaal 1.053 hectare geruild. Hiermee is inmiddels volgens de Overijsselse methode 5.505 hectare landbouwstructuurversterking gerealiseerd ${ }^{10}$. In totaal wordt er met de

\footnotetext{
9 Peildatum 10 oktober 2018

${ }^{10}$ Alle genoemde resultaten landbouwstructuurversterking zijn gebaseerd op opgaves van de initiatiefnemers per project. Deze hebben hiervoor de Overijsselse methode toegepast. Zie voor uitleg van deze methode paragraaf 1.5.
} 
projecten 16.598 hectare landbouwstructuurversterking beoogd. Als dit wordt gehaald, wordt hiermee ruimschoots voldaan aan de beoogde 12.500 hectare landbouwstructuurversterking. Daarbij moet worden aangetekend dat ook de POP3-projecten in deze prognose zijn meegenomen. Deze projecten worden slechts voor de helft uit het oorspronkelijke programma gefinancierd. Daar staat tegenover dat er ook middelen uit het programma zijn overgeheveld naar de ontwikkelopgave Natura 2000/PAS.
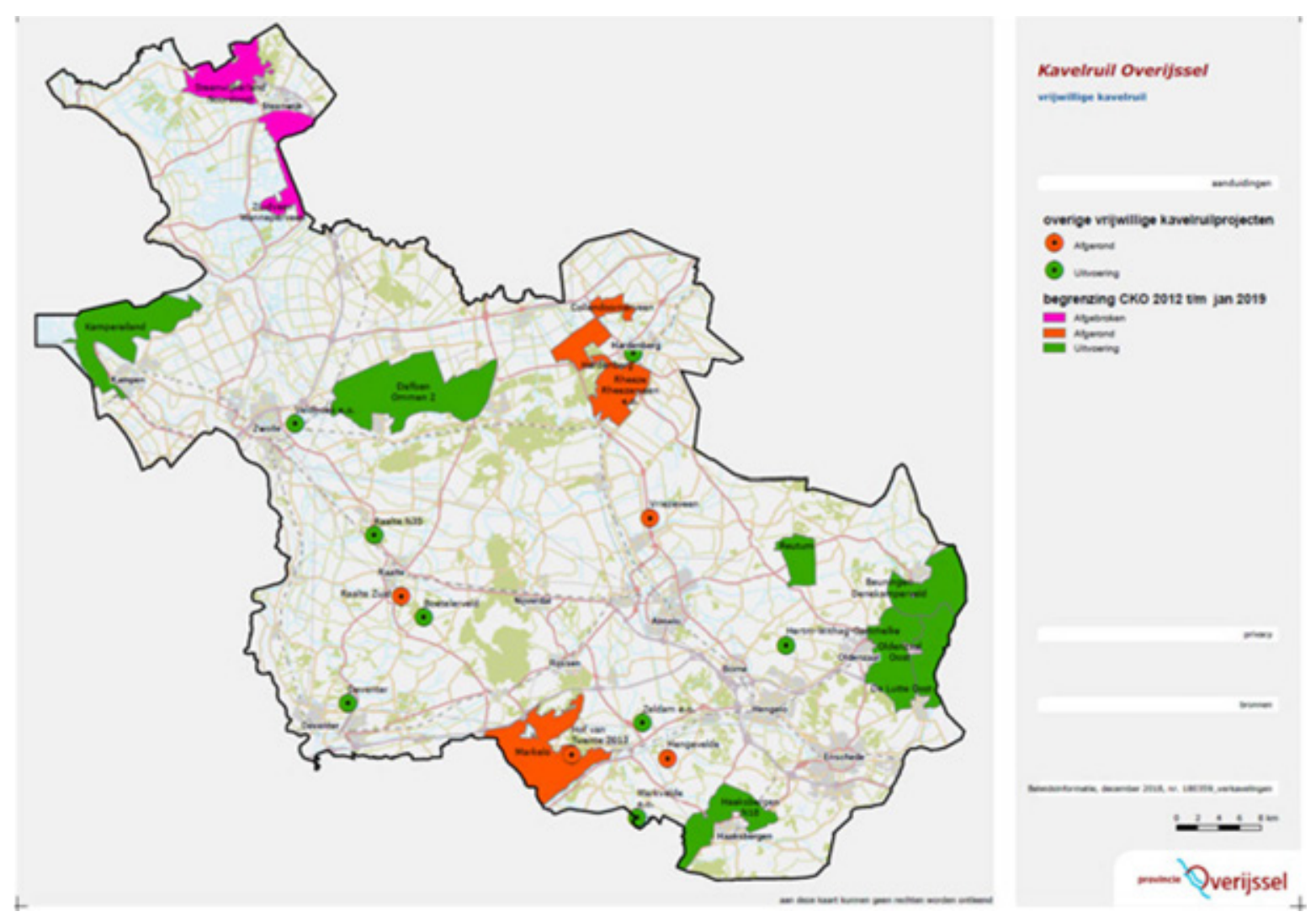

Figuur 2.1 Locatie vrijwillige kavelruilprojecten in Overijssel (2012-2018).

Hoewel op basis van de prognose verwacht mag worden dat de doelstelling ruimschoots wordt gehaald, is dat wel ruim later dan voorzien (2021 in plaats van 2018). De vertraging is ontstaan doordat het programma relatief traag op gang kwam en sommige projecten langer duren dan voorzien. Zo zijn de drie grote CKO-projecten in Losser pas in 2016 gestart en startte Dalfsen-Ommen pas echt in 2017. Bovendien werden de CKO-projecten Steenwijkerland-Noordoost en Wanneperveen/Zuidveen vroegtijdig afgebroken, waarna CKO op zoek moest naar nieuwe initiatieven om aan haar prestatiedoelstelling te voldoen. Verder ontstond er forse vertraging in de projecten Haaksbergen en Boetelerveld. Na de openstelling van POP3 in 2016 kwamen er bovendien nog eens acht projecten bij waarvan realisatie wordt voorzien in de periode 2018-2021.

Vertraging in de opstart of uitvoering van projecten ontstaat vaak als ruimtelijke ontwikkelingen die in het betreffende gebied spelen, zoals de tracékeuze van een weg, de begrenzing van de Ontwikkelopgave Natura 2000/PAS of de precieze invulling van de PAS-maatregelen die genomen moeten worden, nog niet duidelijk zijn (zie ook kader 2.1). Er wordt dan later gestart of men wacht met het opstellen van ruilplannen totdat er meer duidelijkheid is over deze ontwikkelingen. Ook komt het voor dat er onvoldoende ruilgrond aanwezig is in het projectgebied of verworven kan worden, waardoor het lastig is ruilplannen rond te zetten. Ten slotte kunnen inschattingen van potentiële belangstelling op basis van quickscans of consultaties vooraf als het erop aankomt te optimistisch blijken, waardoor er veel tijd en energie moet worden gestoken in het enthousiasmeren van potentiële deelnemers en/of projecten worden afgebroken (zie ook kader 2.3).

In veel projecten komen ook andere doelen dan landbouwstructuurversterking aan bod, zoals natuurontwikkeling, waterberging of recreatie. Op basis van de beschikbare gegevens en 
groepsgesprekken kunnen we concluderen dat er sprake is van de realisatie van 33 ha natuurdoelen en 13,6 ha waterdoelen (zie ook bijlage 2 en kaders). Ook kunnen we op basis van de beschikbare gegevens constateren dat er een verband is tussen de resultaten op andere terreinen en de mate waarin projecten zich daar expliciet op richten. Zo lijkt het nog niet afgeronde integrale project Boetelerveld een duidelijke bijdrage te gaan leveren aan de realisatie van de Natura 2000-/PASontwikkelopgave voor het Boetelerveld, omdat het project zich daar van meet af aan op richtte en het kavelruilproces afstemt op de voortgang van de Natura 2000-/PAS-ontwikkelopgave (zie kader 2.1). De informatie over de resultaten van het Programma Landbouwstructuurversterking voor andere doelen dan landbouwstructuurversterking is echter niet volledig. Dit heeft te maken met de gevraagde projectverantwoording aan de provincie. Hierin wordt niet naar bredere doelrealisatie gevraagd.

\section{Kader 2.1: Integrale kavelruil rond het Boetelerveld}

Het Boetelerveld is een natuurgebied van ruim 170 hectare in eigendom van Landschap Overijssel dat door de aanwezigheid van bijzondere natuur in 2013 is aangewezen als Natura 2000-gebied. Om de natuurwaarden in dit gebied te behouden en te ontwikkelen, moeten er diverse herstelmaatregelen worden uitgevoerd in en om het gebied. In een bufferzone rond het gebied gaat het vooral om het verondiepen en dempen van sloten. Omdat de uitvoering van de maatregelen negatieve gevolgen heeft voor de landbouw (o.a. vernatting), pleitte LTO Salland ervoor gelijktijdig te werken aan landbouwstructuurverbetering in een groter gebied, zodat bedrijven die direct geraakt worden door de maatregelen voldoende kunnen worden gecompenseerd met grond. Daarnaast gaf het Waterschap aan zijn wateropgave in de omgeving van het Boetelerveld mee te willen laten liften met het gebiedsproces. Deze diverse wensen en opgaven waren voor LTO Salland en gemeente Raalte aanleiding om in 2014, gekoppeld aan een subsidieaanvraag voor het Natura 2000-gebiedsproces, een projectaanvraag in te dienen voor het integrale kavelruilproject in een ruim gebied rondom het Boetelerveld. Naast landbouwstructuurversterking ging het hierbij om het uitvoeren van de herstelmaatregelen in de bufferzone, grondcompensatie voor boeren met gronden met een gebruiksbeperking in de bufferzone en het realiseren van waterberging.

De keuze voor planmatige, vrijwillige kavelruil kwam niet uit de lucht vallen. In de jaren ervoor was er in Salland veel ervaring opgedaan met grote vrijwillige kavelruilprojecten. LTO Salland trad daarbij op als initiator en trekker en de gemeenten als facilitator. De uitvoering was in handen van een kavelruilcommissie, ondersteund door een kavelruil- en projectcoördinator. In opeenvolgende projecten zijn zodoende honderden hectares van eigendom gewisseld, waarmee de landbouwstructuur is verbeterd en ook andere doelen zijn gerealiseerd. Door de reeks van projecten groeide bovendien het vertrouwen tussen vertegenwoordigers van natuur-, landbouw- en waterbelangen. Partijen zitten er volgens een betrokkene in Salland 'niet geharnast in' en begrijpen dat ze samen verder moeten. De hoge organisatiegraad van de boeren ( $80 \%$ is lid van LTO) speelt ook een rol bij het succes. "Als LTO iets oppakt in dit gebied, dan is er steun bij de boeren", zo verwoordt een deelnemer aan meerdere kavelruilen.

De uitvoering van het project verliep voorspoedig: eind 2016 was er rond het Boetelerveld al 178 hectare geruild voor landbouwstructuurversterking. Ook werd er grond vrijgespeeld voor wateropgaven (6,9 hectare) en voor de Natura 2000-opgave (23 hectare). Toen moest volgens de projectleider 'de rem erop' om voldoende ruilmogelijkheden te houden voor de grondeigenaren in de bufferzone. Het wachten was op verdere uitwerking van de herstelmaatregelen en duidelijkheid over de schade. Inmiddels (december 2018) is die duidelijkheid er wel en wordt de komende maanden met alle grondeigenaren rond het Boetelerveld een groot ruilplan gemaakt om de natuuropgave voor het Boetelerveld te realiseren en de grondeigenaren compensatiegrond te bieden. Dat is het sluitstuk van het kavelruilproject.

Naast de integrale aanpak, de onafhankelijke rol en de gebiedskennis van de gebiedscoördinator en het meebewegen met de ontwikkelingen in het gebied, noemen betrokkenen ook de regie op de grond bij de kavelruilcommissie als belangrijke succesfactor in dit proces. Bij gronden van eigenaren die geen eigendom hebben in de bufferzone, ligt de volledige regie over de inzet van deze gronden bij de kavelruilcommissie. Voor gronden die de provincie verwerft voor realisatie van de ontwikkelopgave Natura 2000/PAS ligt het ingewikkelder. De provincie heeft hier de regie, maar de kavelruilcommissie brengt over iedere aankoop van de provincie een zwaarwegend advies uit. Ook kan de kavelruilcommissie de provincie een onderbouwd voorstel doen over de inzet van de door haar aangekochte gronden in het gebiedsproces. Hiermee wil de kavelruilcommissie voorkomen dat de provincie de gronden (te lang) in portefeuille houdt. De provincie wil op haar beurt zekerheid over volledige en tijdige doelrealisatie. Dit leverde soms wat spanning op, maar over het algemeen is de kavelruilcommissie tevreden over het vertrouwen dat men heeft gekregen. 
Ook wordt niet bijgehouden welk type bedrijven meedoet. Wel is duidelijk dat het voornamelijk melkveehouders zijn die participeren. Respondenten geven verder aan dat het vooral gaat om toekomstgerichte ondernemers die door willen met hun bedrijf. Dat hoeven niet alleen bedrijven te zijn die zich richten op schaalvergroting. Voor alle ondernemers met een substantiële landbouwtak is het aantrekkelijk om grond dichter bij huis te hebben. En voor stoppers kan het aantrekkelijk zijn om grond binnen een kavelruilproject te verkopen, omdat ze dan niet zelf een keuze hoeven te maken aan wie ze de grond verkopen. Dit betekent dat blijvende bedrijven de mogelijkheid hebben om binnen een kavelruilproject hun bedrijfsoppervlakte te vergroten.

\subsection{Slaag- en faalfactoren}

Voor het bereiken van de beschreven resultaten op het vlak van landbouwstructuurversterking spelen verschillende slaag- en faalfactoren in de uitvoering een rol. Daar gaan we in het onderstaande op in.

Een belangrijke factor voor het slagen van kavelruilprojecten is het goed en flexibel kunnen inspelen op de wensen in het gebied. De huidige aanpak, waarbij het initiatief voor kavelruil komt vanuit de agrarische sector en de landbouw via de kavelruilcommissie de regie heeft over het kavelruilproces, heeft volgens betrokkenen veel voordelen. Gebiedskennis kan zo optimaal worden benut en de aanpak geeft vertrouwen bij potentiële agrarische deelnemers. Ook de rol en de persoon van de kavelruilcoördinator zijn daarbij van cruciaal belang. Om als oliemannetje en vertrouwenspersoon te kunnen fungeren, moet de kavelruilcoördinator de mensen en de cultuur in het gebied goed kennen, de taal van de boeren spreken, hen kunnen verleiden om mee te doen en flexibel in kunnen spelen op kansen wanneer die zich voordoen. Het is bovendien belangrijk dat de kavelruilcoördinator geen eigen belangen heeft bij de kavelruil en dus onafhankelijk is. Daarnaast moet de kavelruilcoördinator een brede blik hebben om ook particulieren en andere belanghebbenden bij het proces te kunnen betrekken.

Ook de aanwezigheid van voldoende ruilgrond bij aanvang van het project is van doorslaggevend belang voor succes. Volgens een betrokkene is het de vraag of je zonder ruilgrond überhaupt aan een kavelruilproject moet willen beginnen. Daar staat tegenover dat het kavelruilproces er ook toe kan leiden dat grondeigenaren zich bezinnen op de toekomst van hun bedrijf en als gevolg hiervan grond willen verkopen. Het Revolving Fund van de provincie Overijssel is een belangrijke faciliteit om grond die beschikbaar komt aan te kopen en in te kunnen zetten als ruilgrond. Ook de Grondbank Salland werd eerder ingezet om de beschikking te krijgen over ruilgrond voor kavelruilprojecten. Soms wordt grond die beschikbaar komt alvast gekocht, maar nog niet betaald. Die grond wordt dan tijdelijk aan andere boeren verpacht en de oorspronkelijke eigenaar krijgt pas zijn geld als de grond daadwerkelijk verkocht is. Het op een slimme manier schuiven met gronden, ook in de tijd, is volgens een betrokken kavelruilcoördinator de sleutel tot het succes van een kavelruil.

Verschillende betrokkenen noemen als faalfactor dat de provincie niet snel genoeg kan schakelen wanneer zich kansrijke transacties voordoen. Het komt dan voor dat de grond dan al naar een andere koper is gegaan. De snelheid van handelen van de provincie hangt samen met de taxatie die nodig is bij de inzet van het Revolving Fund. Pas als de grond is getaxeerd door een onafhankelijk taxateur en de taxatiecommissie dit heeft beoordeeld, kan tot aankoop worden overgegaan.

Ook kent de inzet van het Revolving Fund bepaalde beperkingen die sommige respondenten als nadeel ervaren. Zo is de aankooptitel gebonden aan een bepaald project en kan er voorafgaand geen ruilgrond worden aangekocht. Ook aankoop van gebouwen is niet mogelijk met het Revolving Fund. Dit kan het onaantrekkelijk maken voor boeren om hun bedrijf te verkopen of te verplaatsen. Dit soort restricties op de inzet van het Revolving Fund beperken de mogelijkheden om ruilgrond aan te kopen en in te zetten voor ruilingen. Daar staat tegenover dat verruiming van de inzet ertoe kan leiden dat de provincie met ruilgrond, en met name gebouwen, blijft zitten.

Een integrale aanpak waarin van meet af aan naast landbouwstructuurversterking ook andere doelen in de kavelruil worden betrokken, is volgens een aantal betrokkenen ook een succesfactor. LTO Salland en de gemeente Raalte hebben goede ervaringen opgedaan met projecten waarin opgaven 
worden gecombineerd en er naast verbetering van de landbouwstructuur ook grond wordt vrijgespeeld voor natuur- en wateropgaven. Hun uitgangspunt is dat naarmate er meer deelnemers en belangen participeren, er meer grond wordt ingebracht en er meer ruilmogelijkheden ontstaan, ook voor de landbouw. Waterschappen liften graag mee op kavelruilprocessen om gronden te ruilen voor bijvoorbeeld de inrichting van natuurvriendelijke oevers of waterberging. Het helpt daarbij als locaties voor het realiseren van waterdoelen nog niet zijn vastgelegd. De provincie kiest op dit moment niet voor het instrument planmatige kavelruil voor het realiseren van de Natura 2000-/PAS-ontwikkelopgave, maar ondersteunt wel kavelruilinitiatieven van anderen die hieraan kunnen bijdragen.

Kader 2.2: Hof van Twente 2013 als onderdeel van een continu kavelruilproces

Sinds 2007 hebben er in de gemeente Hof van Twente diverse kavelruilprojecten gelopen. De resultaten van eerdere vrijwillige kavelruilprojecten in het gebied leidden in 2013 tot het opzetten van het kavelruilproject Hof van Twente 2013. Grondeigenaren die eerder nog terughoudend waren, zagen structuurverbeteringen om zich heen en wilden zelf ook de kansen voor structuurverbetering benutten via vrijwillige kavelruil. Bovendien was er een concreet initiatief van een makelaar in Markelo en een paar agrarische grondeigenaren. Daarnaast lag er rondom de Regge nog 17 hectare BBL-grond, waarvan een deel kon worden ingezet voor verkoop of ruil voor landbouwstructuurversterking.

Naar aanleiding van een LTO-afdelingsavond, waar de gebiedsmanager van Stimuland de mogelijkheden voor kavelruil presenteerde, meldden zich nog meer belangstellenden. Nadat de provincie en de gemeente subsidie hadden toegezegd, kon men aan de gang. Er werd in drie deelgebieden gewerkt. Uiteindelijk lukte het om binnen een jaar vier ruilplannen te realiseren met in totaal 48 deelnemers, waarbij 48 hectare werd geruild.

Voor het deelgebied Hazendam werden twee opeenvolgende ruilplannen gemaakt. Volgens een deelnemer heeft hier 'een behoorlijke opschoning' plaatsgevonden in de vaak zeer kleine veldpercelen. Het Waterschap kon de stroken langs de Boven Regge vrij krijgen met inzet van de BBL-grond en eigen grond. Er werd een waterbergingsgebied ingericht als zogenaamd rabattenbos met elzen. De bomen staan hier op ophogingen met daartussenin greppels waar het water doorloopt. De gemeente heeft er inmiddels een recreatief fietspad doorheen gelegd, met een brug over de Regge, en er is een kunstwerk geplaatst. Volgens een betrokken agrariër is hierdoor een uniek plekje ontstaan, waar recreanten volop van genieten. Daar staat tegenover dat de samenvoeging van de perceeltjes langs de Regge tot een groot, open veld, minder goed uitpakt voor het oorspronkelijke coulissenlandschap.

Een belangrijke succesfactor voor de kavelruil was volgens verschillende betrokkenen de aanwezigheid van ruilgrond. Daardoor hoefde men niet te wachten op een aankooptitel van de provincie en kon er vaart worden gemaakt. De korte lijntjes met de gemeente en de inzet van de gebiedsmanager, die van de diverse initiatieven één project smeedde, waren ook belangrijk. Dit droeg bij aan het continue proces van kavelruil in het gebied, waar de kavelruilcommissie aan werkt.

Andere betrokkenen zien ook risico's van een integrale aanpak. Als niet-landbouwbelangen in een gebied de overhand krijgen, zal dat negatief uitpakken voor het vertrouwen van boeren in het kavelruilproces en hun bereidheid om deel te nemen, vrezen zij (zie ook kader 2.3). Voor CKO, opgericht voor het ondersteunen van landbouwstructuurversterking, is het vooropstellen van landbouwstructuurversterking een belangrijke succesfactor voor het slagen van kavelruil. Langzamerhand is echter ook CKO steeds vaker actief in gebieden waar natuur-, water en recreatieopgaven spelen. Voor zover niet strijdig met de landbouwdoelen betrekt CKO deze opgaven erbij, maar de landbouwstructuurversterking blijft voor deze organisatie centraal staan.

Timing kan een cruciale succes- of faalfactor zijn in kavelruilprojecten. Vooral in gebieden waar meerdere opgaven spelen, komt het vaak voor dat het proces van kavelruil niet in de pas loopt met andere plan- en uitvoeringsprocessen, wat de kans op succesvolle koppelingen vermindert of het kavelruilproces vertraagt. Zo moest het kavelruilproces rond het Boetelerveld tijdelijk worden stopgezet, omdat de PAS-herstelmaatregelen nog niet duidelijk waren en de kavelruilcommissie voldoende compensatiegrond wilde kunnen bieden aan de boeren in de bufferzone (zie kader 2.1). In het kavelruilproject Vriezenveen koos men er juist voor de oostzijde van het Natura 2000-gebied Engbertsdijkvenen maar buiten beschouwing te laten, omdat er tijdens de uitvoeringsperiode van de kavelruil nog veel discussie was over de PAS-maatregelen en erop wachten de uitvoering van de kavelruil zou vertragen. 
De aanwezigheid van een gebiedsmanager of -coördinator is ook een belangrijke succesfactor voor het tot stand komen van kavelruilprojecten. Voordeel is dat deze mensen op continue basis kansen voor kavelruil kunnen inventariseren in de gebieden waar ze actief zijn. Nadeel is dat niet alle Overijsselse gemeenten een dergelijke faciliteit financieren.

Gebiedsspecifieke factoren spelen ook een belangrijke rol bij het succes of falen van kavelruil. Zo zijn gronden in bepaalde gebieden moeilijk uitwisselbaar door grote verschillen in kwaliteit. Dit maakt het dan erg lastig om tot overeenstemming te komen. Ook verschillen in ondernemerschap tussen en zelfs binnen gebieden spelen een rol. Over het algemeen zijn het de meer toekomstgerichte ondernemers die de voordelen zien van kavelruil. In gebieden waar weinig toekomstgerichte ondernemers zijn, komt kavelruil veelal niet van de grond. Ook eerdere positieve ervaringen met kavelruil zijn een succesfactor. In gebieden waar met succes kavelruilen zijn afgerond, brengt dat vaak een sneeuwbaleffect op gang van nieuwe initiatieven (zie kader 2.2). Andersom kan natuurlijk ook: eerdere negatieve ervaringen verminderen de deelnamebereidheid. Verder zijn ook culturele factoren van belang. In Twente zijn boeren over het algemeen sterk gehecht aan het bezit van hun grond, wat de deelnamebereidheid aan kavelruil vermindert. Animositeit ('het elkaar niet gunnen') tussen boeren in bepaalde gebieden kan de samenwerking belemmeren. Soms kan het niet meedoen van één grondeigenaar het totaalresultaat sterk negatief beïnvloeden.

Programmafinanciering, zoals CKO ontvangt voor het ondersteunen van kavelruil, zorgt volgens verschillende initiatiefnemers voor flexibiliteit en snelheid bij de start van kavelruilprojecten. Het geeft meerjarige zekerheid over middelen en vermindert de administratieve lasten gemoeid met aparte projectaanvragen en -verantwoording. Dit laatste speelt nog eens extra bij de POP3-aanvragen waarvoor extra strenge voorwaarden gelden. Ook maakt programmatische financiering het makkelijker een continue stroom van kavelruilprojecten te ondersteunen, zoals actieve gemeenten als Hof van Twente en Raalte voorstaan. Dit laat onverlet dat deze gemeenten ook met een projectmatige aanpak een reeks van succesvolle kavelruilen hebben afgerond.

De programmafinanciering van CKO heeft verder geholpen om in gebieden waar de gemeente initiatieven voor kavelruil niet actief ondersteunt, toch kavelruilprojecten van de grond te tillen. Het programmabudget geeft CKO de mogelijkheid om de voordelen van kavelruil actief onder de aandacht te brengen in gebieden waar kansen liggen.

Het niet goed betrekken van landschap in kavelruil is een potentiële faalfactor. Soms verdwijnen landschapselementen als kavels worden samengevoegd of worden kansen voor landschapsversterking niet benut. Dit kan het draagvlak voor kavelruil bij burgers en buitenlui ondermijnen.

Er zijn ten slotte diverse 'proceshandigheidjes' die bijdragen aan succes. Zo is het belangrijk om naast agrarische ook particuliere grondeigenaren goed bij het proces te betrekken en hen waar mogelijk 'mee te laten liften'. Dit kan bijvoorbeeld door kleine overdrachten waar particulieren belang bij hebben, mee te nemen in de kavelruil, zodat ze vrijgesteld zijn van overdrachtsbelasting. Een andere mogelijkheid is eigendommen die in het verleden niet goed ingemeten zijn, nu in het kavelruilproces goed vast te leggen. Dit vergroot het draagvlak voor kavelruil en kan bijdragen aan het succes van toekomstige kavelruilen. Verder is het belangrijk te respecteren wat grondeigenaren willen, maar ook duidelijke deadlines te hanteren. Ook het flexibel omgaan met projectgrenzen zodat kansen voor ruil met omliggend gebied gepakt kunnen worden, kan bijdragen aan het slagen van een project. 
LTO Noord afdeling Hardenberg nam in 2014 het initiatief voor een vrijwillige kavelruil in het gebied Rheeze-Rheezerveen. Stichting Coördinatiepunt Kavelruil Overijssel (CKO) werd gevraagd om hen hierin te ondersteunen. Aanleiding was de wens om tot een efficiëntere verkaveling te komen en hiermee de concurrentiepositie van de landbouwbedrijven te versterken. Op basis van een quickscan van de verkavelingssituatie van het Kadaster en een voorlichtingsbijeenkomst in het gebied, concludeerde de initiatiefgroep dat er voldoende animo en mogelijkheden waren voor het starten van een vrijwillige kavelruil.

Het belangrijkste doel was de verbetering van de structuur van de grondgebonden landbouw. Meer in het bijzonder richtte het project zich op de vergroting van de huiskavels, de vergroting van de veldkavels, de vermindering van het aantal veldkavels en het verkrijgen van veldkavels dichter bij huis. Natuur en andere doelen konden volgens de kavelruilcommissie, indien mogelijk, meeliften op de kavelruil, maar landbouwstructuurversterking stond voorop.

Het project kende een moeizame start. Een complicerende factor was het Ruimte voor de Vecht-project van de provincie en het Waterschap, gericht op een natuurlijker inrichting van de Vecht. In het deelgebied Rheerzermaten liep al een kavelruilcoördinator rond voor Ruimte voor de Vecht, maar de gesprekken met de boeren verliepen stroef. Daar kwam toen nog een kavelruilcoördinator bij vanuit het CKO-project. Deze gang van zaken maakte veel boeren in het deelgebied Rheeze kopschuw. De deelnamebereidheid was daar volgens een betrokkene bijzonder laag, terwijl er toch voldoende agrariërs zitten die door willen. Ook boeren die niet meer actief waren, wilden hun grond niet inbrengen in de kavelruil. Een andere hobbel waren de onderhandelingen over de aankoop van een bedrijf in Rheezerveen die op niets uitliepen. Hierdoor werd 17 hectare ruilgrond misgelopen en liep het project de nodige vertraging op. Gaandeweg bleek er bovendien te weinig draagvlak in het gebied voor de kavelruilcoördinator van het CKO-project. Toen deze was vervangen door de voorzitter van de kavelruilcommissie met ondersteuning van het Kadaster, kwam het proces beter op gang. Er kon uiteindelijk ook grond worden aangekocht van een stoppende agrariër, hetgeen de ruilmogelijkheden aanzienlijk vergrootte.

Ruim drie jaar na de aftrap van het kavelruilproject kon het proces in maart 2017 worden afgesloten. Er zijn uiteindelijk twee ruilplannen tot stand gekomen en er is bijna 100 hectare geruild tussen 23 eigenaren. Vooral het dichterbij krijgen van in totaal 50 hectare grond tikt aan. Deelnemende boeren besparen hierdoor fors op rijtijden. Daarnaast is er bij de Vecht 5 hectare vrij geruild voor natuurontwikkeling. Betrokkenen zijn het erover eens dat elke ruiling positief is, maar dat er voor het gebied meer in had gezeten. De vertraging in de beginfase, de stijgende grondprijzen en het gebrek aan ruilgrond waren hier debet aan.

\subsection{Concluderend}

De Provincie Overijssel investeerde in de periode 2012-2018 ruim 6 miljoen euro in landbouwstructuurversterking via het Programma Landbouwstructuurversterking en POP3. Daarnaast zette de provincie het Revolving Fund in voor de aankoop van ruilgrond in kavelruilprojecten. De uitvoering van het programma gebeurde door CKO, individuele gemeenten en Stimuland, in samenwerking met kavelruilcommissies, naar aanleiding van vragen uit de gebieden. Er zijn in de uitvoeringsperiode 24 projecten gestart. De prognose is dat hiermee bijna 17.000 hectare landbouwstructuurversterking wordt gerealiseerd. Dit is ruim meer dan de doelstelling van het programma. Wel is er forse vertraging ontstaan in de uitvoering van het programma. De laatste projecten worden in 2021 afgerond in plaats van in 2018.

Belangrijke slaagfactoren in de uitvoering van het programma waren: het goed en flexibel in kunnen spelen op de wensen en omstandigheden in de gebieden, de beschikbaarheid van ruilgrond en de continue aanwezigheid van een gebiedsmanager of -coördinator als aanspreekpunt. De programmafinanciering waarover CKO beschikte, zorgde verder voor flexibiliteit en snelheid bij de start van kavelruilprojecten.

Faalfactoren waren: de beperkte mogelijkheden van de provincie om snel te kunnen handelen als zich kansen voor grondaankoop voordeden, het niet in de pas lopen van het kavelruilproject met andere ruimtelijke ontwikkelingen en het niet goed betrekken van landschapskwaliteit in de kavelruil. 
$\mathrm{Er}$ is discussie over de vraag wat het effect is van een integrale aanpak in kavelruilprojecten. Volgens sommigen levert dit meer mogelijkheden voor landbouwstructuurversterking op, doordat meer partijen grond inbrengen. Anderen geven aan dat een integrale aanpak agrarische grondeigenaren kan afschrikken, wat negatief kan uitpakken voor de deelnamebereidheid. Gebiedsspecifieke factoren spelen hierbij een belangrijke rol: rond het Boetelerveld was een integrale aanpak succesvol, terwijl in Rheeze-Rhezerveen het Ruimte voor de Vecht-project juist zorgde voor wantrouwen bij potentiële deelnemers. 


\section{$3 \quad$ Effecten kavelruil}

\section{$3.1 \quad$ Inleiding}

Met de ondersteuning van planmatige, vrijwillige kavelruil richt de provincie zich op het versterken van de toekomstbestendigheid van de landbouw in Overijssel. Dit hoofdstuk gaat over de vraag in welke mate het programma en de gehanteerde aanpak hieraan bijdragen en welke andere effecten er optreden als gevolg van kavelruil.

Om de bijdrage aan de toekomstbestendigheid te bepalen, kijken we op de eerste plaats naar de verbetering van de verkavelingssituatie in gebieden waar kavelruilprojecten hebben plaatsgevonden. Hierbij gaat het allereerst om een vergroting van de huiskavel. Een grote huiskavel is vooral van belang voor melkveebedrijven: zij hebben daarmee meer mogelijkheden om het grasland te gebruiken voor beweiding door het melkvee. Daarnaast kan de huiskavel ook van belang zijn bij bedrijven met intensieve teelten, waarbij sprake is van intensief management en veel bewerkingen voor bepaalde gewassen. Een korte afstand tot de veldkavels is voor alle bedrijfstypen van belang: er gaat dan minder tijd en energie verloren met het verkeer van en naar de kavels. Concentratie van percelen in minder veldkavels leidt tot minder tijd- en energieverlies doordat minder transporten tussen bewerkingen nodig zijn. We gaan er in dit onderzoek van uit dat als de landbouwstructuur op gebiedsniveau verbetert, dit gunstig is voor de toekomstbestendigheid van de sector.

Op de tweede plaats kijken we naar de bijdrage van kavelruil aan de economische positie van de betrokken bedrijven. Hiervoor onderzochten we de financiële voordelen die deelnemende bedrijven hebben van kavelruil. We gaan ervan uit dat een betere economische positie van individuele bedrijven de toekomstbestendigheid van de sector vergroot.

In paragraaf 3.2 gaan we in op de afbakening van de analyse. De effecten van kavelruil op de landbouwstructuur in gebieden worden besproken in paragraaf 3.3. De bedrijfseconomische effecten komen aan bod in paragraaf 3.4. In paragraaf 3.5 gaan we in op overige (potentiële) effecten van kavelruil. We sluiten in paragraaf 3.6 af met conclusies. Een uitgebreide beschrijving van de gemaakte methodische keuzes en resultaten van de analyse van de effecten op landbouwstructuur en de bedrijfseconomische effecten staan respectievelijk in bijlage 3 en 4.

\subsection{Afbakening}

Alleen projecten die in periode 2013-2017 zijn afgerond en waarbij sprake is van een ruilresultaat zijn in de analyse betrokken. Uitzondering zijn Reutum en Markelo die nog niet zijn afgerond in 2017, maar waar al wel een flinke ruilresultaten zijn geboekt. Deze projecten zijn wel in de analyse meegenomen. De gebiedsanalyse is verder beperkt tot de CKO-projecten, omdat hiervan projectbegrenzingen beschikbaar was. Projectbegrenzingen zijn nodig om van het plangebied de verkavelingssituatie voor en na de ruilingen te bepalen. Voor de bedrijfseconomische analyse zijn daarnaast ook deelnemende bedrijven uit drie niet-CKO projecten meegenomen. De analyse is verder beperkt tot melkveebedrijven, omdat in Overijssel het merendeel van de landbouwbedrijven die aan vrijwillige kavelruilprojecten deelneemt uit melkveebedrijven bestaat en voor deze bedrijven al een deel van de verkavelinggegevens beschikbaar waren. 


\subsection{Effecten op landbouwstructuur}

\section{Aanpak}

Om de bijdrage van de kavelruil aan de verbetering van de landbouwstructuur van het gebied te kunnen bepalen, is gekeken naar de volgende verkavelingskenmerken van de situatie vóór en na de uitvoering van de kavelruilprojecten in vergelijking met gebieden waarin (nog) niet geruild is. De volgende zaken waren hierbij aan de orde:

- Aandeel huisbedrijfskavel per bedrijf; dit is gedefinieerd als de percelen die een bedrijf in gebruik heeft en tezamen een kavel vormen, die grenst aan het erf met de bedrijfsgebouwen (huiskavel), inclusief de gebruikspercelen die een kavel vormen aan de overzijde van een lokale weg, grenzend aan de huiskavel (en die daarmee ook bereikbaar zijn voor beweiding).

- Kavelafstand over de weg (eventueel onderverdeeld in verhard, onverhard, water).

- Aantal veldkavels per bedrijf; een veldkavel is een aaneengesloten stuk grond dat een bedrijf in gebruik heeft, bestaande uit één of meer gewaspercelen, die onderling zijn verbonden en bereikbaar zijn en niet van elkaar worden gescheiden door brede waterlopen, (spoor)wegen of percelen van een andere ondernemer.

In dit project is een GIS-analyse uitgevoerd op basis van de Basisregistratie Percelen (BRP), waarmee de huisbedrijfskavels en de veldkavels zijn bepaald, inclusief de afstanden van de veldkavels over de weg (zie verder bijlage 3 ).

\section{Resultaten}

Tabel 3.1 omvat de huisbedrijfskavelbepaling van de melkveebedrijven in de CKO-projectgebieden in 2017 vergeleken met de situatie in 2013. In de gebieden waar ruilingen gerealiseerd zijn, is de huisbedrijfskavel van de melkveebedrijven met gemiddeld 2,3 hectare toegenomen, in de overige CKO-gebieden, waar nog niet is geruild, met 1,3 hectare. Opvallend is het gebied Collendoornerveen, waar het grote aandeel geruilde grond heeft geleid tot een toename van de gemiddelde huisbedrijfskavel met 10 hectare. Omdat de groei van de huisbedrijfskavel geen gelijke pas heeft gehouden met de groei van de totale bedrijfsoppervlakte (ruim 30\% t.o.v. 2013), is het percentage huisbedrijfskavel in alle gebieden afgenomen. In de gebieden met gerealiseerde kavelruilen is de afname in het percentage huisbedrijfskavel wel iets kleiner dan in de overige gebieden. We kunnen concluderen dat de schaalvergroting in de melkveehouderij overal bijdraagt aan een flinke afname van het aandeel huisbedrijfskavel. In de gebieden met kavelruilprojecten is deze teruggang minder groot dan in gebieden waar nog niet is geruild.

Tabel 3.1 Aandeel huisbedrijfskavel van melkveebedrijven in 2017 in de CKO-projecten, in vergelijking met de situatie in 2013.

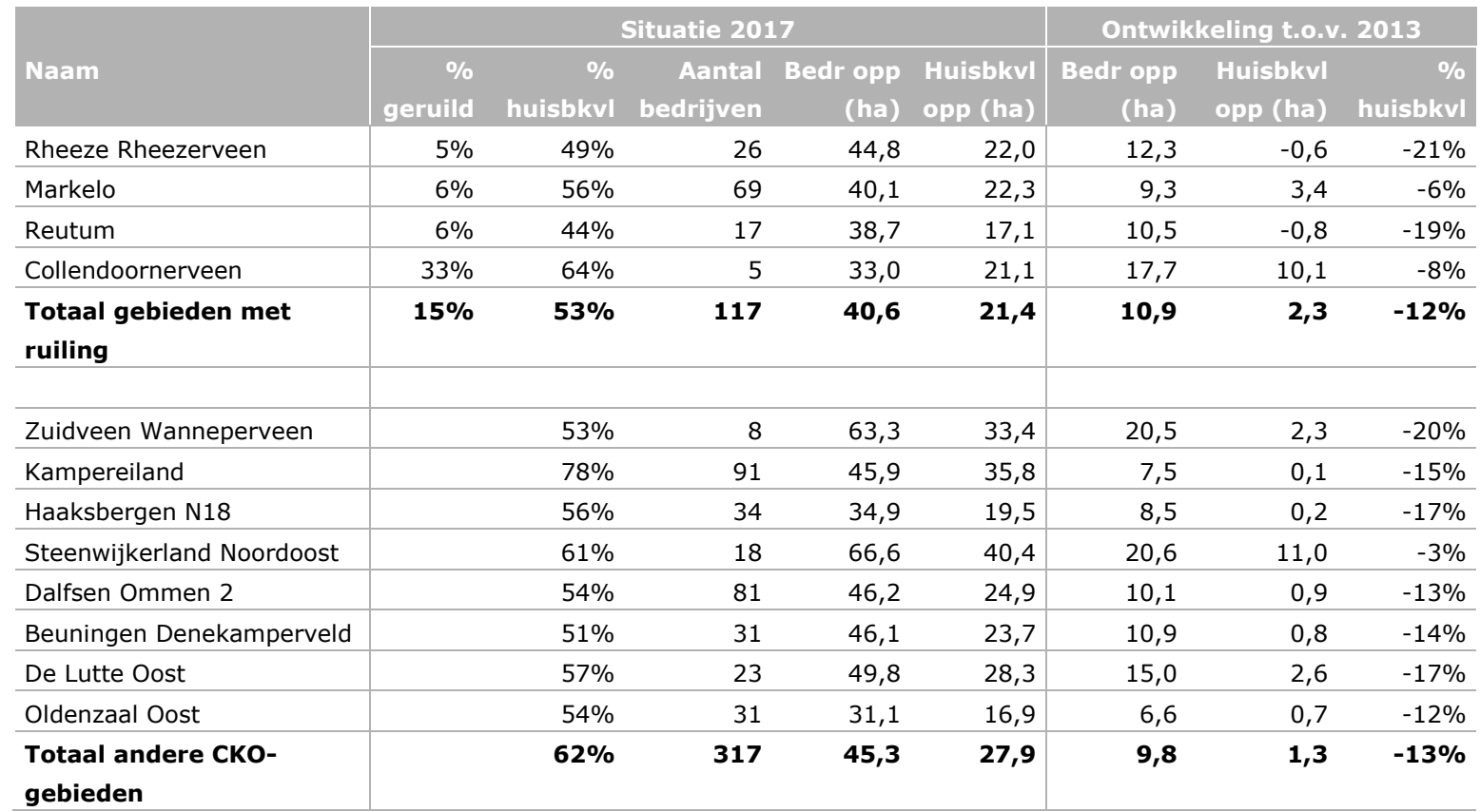


In tabel 3.2 is de ontwikkeling van de perceelafstand weergegeven van de veldkavels. In de gebieden met ruilingen is een afname van de gemiddelde veldkavelafstand gerealiseerd, vooral in Rheeze-

Rheezerveen en Reutum. In de gebieden waar nog niet is geruild, is de afstand met $2 \%$ toegenomen. Dit betekent dat de kavelruilingen met het oog op verkleining van de kavelafstand tot het bedrijf effectief zijn geweest. In Collendoornerveen lijkt vooral ingezet te zijn op vergroting van de huisbedrijfskavel, waardoor de gemiddelde afstand van alle percelen waarschijnlijk wel is verminderd, maar de afstand over de weg voor de percelen op de resterende veldkavels nauwelijks is verkleind.

Tabel 3.2 Ontwikkeling van de gemiddelde kavelafstand in km over de weg van melkveebedrijven in de CKO-projectgebieden.

\begin{tabular}{|c|c|c|c|c|c|}
\hline \multirow[b]{2}{*}{ Naam } & \multirow[b]{2}{*}{$\%$ geruild } & \multirow[b]{2}{*}{ Kvlafst $2013(\mathrm{~km})$} & \multirow[b]{2}{*}{ Kvlafst 2017 (km) } & \multicolumn{2}{|c|}{ Ontwikkeling t.o.v. 2013} \\
\hline & & & & Kvlafst (km) & Kvlafst $\%$ \\
\hline Rheeze - Rheezerveen & $5 \%$ & 1,89 & 1,73 & $-0,16$ & $-8 \%$ \\
\hline Reutum & $6 \%$ & 1,70 & 1,51 & $-0,19$ & $-11 \%$ \\
\hline Collendoornerveen & $33 \%$ & 2,08 & 2,03 & $-0,05$ & $-2 \%$ \\
\hline Zuidveen Wanneperveen & & 1,83 & 2,17 & 0,34 & $19 \%$ \\
\hline Kampereiland & & 4,12 & 3,90 & $-0,22$ & $-5 \%$ \\
\hline Haaksbergen N18 & & 1,91 & 2,19 & 0,28 & $14 \%$ \\
\hline De Lutte Oost & & 3,01 & 3,14 & 0,13 & $4 \%$ \\
\hline Oldenzaal Oost & & 2,79 & 2,59 & $-0,20$ & $-7 \%$ \\
\hline Totaal andere CKO gebieden & & 2,62 & 2,68 & 0,07 & $2 \%$ \\
\hline
\end{tabular}

Tabel 3.3 geeft de ontwikkeling van het aantal veldkavels en de gemiddelde veldkaveloppervlakte voor de melkveebedrijven in de geselecteerde projectgebieden weer. Het blijkt dat de gemiddelde veldkaveloppervlakte in de gebieden die worden voorbereid, in de periode 2013-2017 niet is veranderd. Wel is er gemiddeld per bedrijf ongeveer één veldkavel bijgekomen als onderdeel van het proces van schaalvergroting. In de gebieden waar al wel ruilingen zijn gerealiseerd, is de toename van het aantal kavels iets minder en worden de kavels gemiddeld iets groter. De ruilingen hebben dus een positief effect op de concentratie van percelen in kavels gehad. Vooral in Rheeze-Rheezerveen is dat effect zichtbaar: de kaveloppervlakte is hier het meest toegenomen. 
Tabel 3.3 Ontwikkeling gemiddeld aantal veldkavels en gemiddelde kaveloppervlakte van veldkavels van melkveebedrijven in de CKO-projectgebieden.

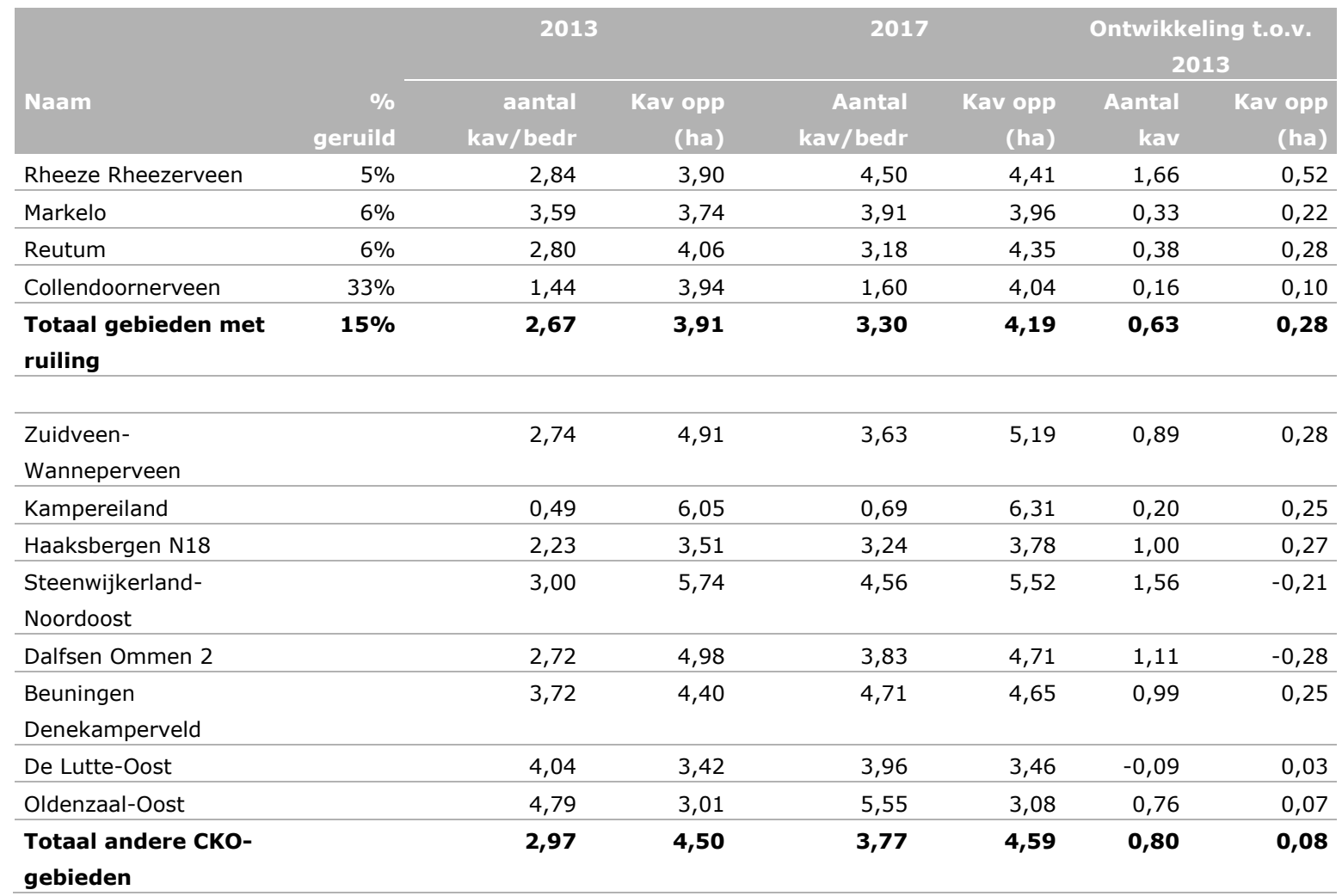

\subsection{Bedrijfseconomische effecten}

\section{Aanpak}

Om de bijdrage van kavelruil aan de economische positie van bedrijven te bepalen, is eerst de fysieke bedrijfsstructuur van deelnemende bedrijven vóór de kavelruil vergeleken met die na de kavelruil. Daarbij zijn op bedrijfsniveau de ontwikkelingen in het aandeel van de huisbedrijfskavel in de totale bedrijfsoppervlakte en in de afstand tot de veldpercelen tussen 2013 en 2017 onderzocht op basis van de Basisregistratie Percelen (BRP). Vervolgens zijn de financiële effecten van deze ontwikkelingen gekwantificeerd met behulp van een daartoe ontwikkeld rekenmodel. Het model is gebaseerd op het werk van Roelofs. ${ }^{11}$ De financiële effecten zijn beperkt tot de veranderingen in bewerkingskosten, inclusief de rijtijden van en naar de percelen (zie verder bijlage 4).

\section{Resultaten}

Tabel 3.4 laat zien dat de gemiddelde oppervlakte van de geanalyseerde melkveebedrijven in de beschouwde periode is toegenomen van 41,2 hectare naar 46 hectare. Dit is vooral gerealiseerd door grondaankoop. De hoeveelheid pacht- en huurgrond is gemiddeld genomen niet veel veranderd. Wel heeft een verschuiving plaatsgevonden van langdurige pacht (reguliere pacht, erfpacht en geliberaliseerde pacht met een looptijd van meer dan zes jaar) naar kortlopende pacht en vergelijkbare huurvormen. Voor de berekening van de financiële effecten zijn alleen de ontwikkelingen meegenomen in de hoeveelheden grond in eigendom en langdurige pacht. Kortlopende pacht- en huurgrond is namelijk geen onderdeel van vrijwillige kavelruil.

De huisbedrijfskavel is gemiddeld genomen groter geworden, maar het percentage huisbedrijfskavel is niet veranderd. De gemiddelde afstand van de veldkavels tot het bedrijfsgebouw is iets afgenomen.

\footnotetext{
${ }^{11}$ Roelofs, P.F.M.M. (2010) Invloed van perceelgrootte op arbeidsbehoefte voor veldwerkzaamheden in de melkveehouderij, Beschrijving en onderbouwing van rekenmodel 'PergroBeko'. Praktijkonderzoek Plant \& Omgeving; Randwijk.
} 
Tabel 3.4 Fysieke bedrijfsindicatoren met betrekking tot kavelruil, gemiddeld over de geselecteerde bedrijven $(n=51)$.

\begin{tabular}{|c|c|c|c|c|}
\hline & Eenheid & 2012 & 2017 & Verschil \\
\hline Oppervlakte & $\mathrm{Ha}$ & 41,2 & 46,0 & $+4,8$ \\
\hline \multicolumn{5}{|l|}{ Waarvan: } \\
\hline - Langdurige pacht & $\mathrm{Ha}$ & 2,3 & 2,0 & $-0,3$ \\
\hline - Kortlopende overeenkomsten & $\mathrm{Ha}$ & 8,6 & 9,4 & $+0,8$ \\
\hline - Grasland & $\%$ & $18 \%$ & $17 \%$ & $-1 \%$ \\
\hline \multicolumn{5}{|l|}{ - Snijmais en ov bouwland } \\
\hline Huisbedrijfskavel & $\mathrm{Ha}$ & 21,8 & 24,3 & $+2,5$ \\
\hline Veldkavel (langdurig) & $\mathrm{Ha}$ & 10,8 & 12,3 & $+1,5$ \\
\hline
\end{tabular}

Uit tabel 3.5 blijkt dat de kavelruil gemiddeld tot een positief financieel effect heeft geleid. Dit effect is becijferd op 27 euro per ha per jaar. Bij een gemiddelde bedrijfsoppervlakte van 46 ha komt dat neer op een financieel voordeel van 1.200 euro per bedrijf. Dit bedrag betreft uitsluitend het effect van vermindering van bewerkingskosten, zoals brandstofkosten en kosten van arbeid en loonwerk. Effecten van autonome verbeteringen in het bedrijfsmanagement (grotere werktuigen, meer melk per koe, voederconversie etc.) zijn niet meegenomen.

Tabel 3.5 Financiële bedrijfsindicatoren met betrekking tot kavelruil, gemiddeld over de geselecteerde bedrijven.

\begin{tabular}{|c|c|c|c|c|}
\hline & Eenheid & 2012 & 2017 & Verschil \\
\hline Bewerkingskosten (bedrijfsniveau) & Euro/bedrijf & 53.800 & 58.800 & +5.000 \\
\hline Bedrijfsoppervlakte & $\mathrm{Ha}$ & 41.2 & 46.0 & +4.8 \\
\hline
\end{tabular}

In tabel 3.6 is de spreiding van het financiële effect van de kavelruil aangegeven. In een aantal gevallen blijkt de situatie in 2017 tot hogere bewerkingskosten per hectare te leiden dan in 2012. Dit is op het eerste gezicht niet logisch, gezien het doel van kavelruil. Toch is er een aantal verklaringen, zoals (1) grondtransacties, die onafhankelijk van de kavelruil zijn gedaan en leiden tot verslechtering van de gemiddelde resultaten per hectare, (2) percelen die ten onrechte als veldkavel zijn aangemerkt, (3) bedrijven die in het kader van bedrijfsopvolging zijn gesplitst en (4) aanleg van wegen tussen 2012 en 2017, waardoor de huisbedrijfskavel is doorsneden.

Op driekwart van de bedrijven die tussen 2012 en 2017 aan kavelruilprojecten hebben deelgenomen, is de verkavelingssituatie in 2017 aantoonbaar gunstiger dan in 2012. Het financiële voordeel kan in individuele gevallen oplopen tot meer dan 150 euro per hectare bedrijfsoppervlakte. Vergeleken met een gemiddeld bedrijfsinkomen van 950 euro per hectare voor melkveehouderijbedrijven in de periode 2018-2018 is dat een flinke besparing.

Tabel 3.6 Spreiding van het financiële effect van kavelruil over de bedrijven (in euro/ha).

\begin{tabular}{lr} 
Nadeel van meer dan 50 euro/ha & Percentage van de bedrijven \\
\hline Nadeel van nul tot 50 euro/ha & $10 \%$ \\
\hline Voordeel van nul tot 50 euro/ha & $15 \%$ \\
\hline Voordeel van 50 tot 100 euro/ha & $40 \%$ \\
\hline Voordeel van 100 tot 150 euro/ha & $15 \%$ \\
\hline Voordeel van meer dan 150 euro/ha & $10 \%$ \\
\hline
\end{tabular}




\subsection{Overige effecten}

Behalve aan de toekomstbestendigheid van de landbouw in Overijssel kan kavelruil ook een positieve bijdrage leveren aan andere doelen van de provincie. Betrokkenen geven aan dat het hierbij op de eerste plaats gaat om het verbeteren van de verkeersveiligheid. Doordat via kavelruil huiskavels groter worden en de afstand tot veldkavels vermindert, nemen de verkeersbewegingen vanuit de landbouw op de vaak kleine binnenwegen af. Zeker gezien het feit dat landbouwvoertuigen steeds groter en breder worden, is dit volgens betrokkenen een belangrijke winst voor de veiligheid en leefbaarheid voor de bewoners in het buitengebied en voor recreanten.

Kavelruilprojecten kunnen daarnaast positieve effecten hebben op het versterken van bijvoorbeeld biodiversiteit, waterveiligheid en beleving. In paragraaf 2.2 kwam reeds aan bod dat een aantal meer integrale kavelruilprojecten daadwerkelijk grond vrijspelen voor natuurontwikkeling, waterberging of recreatie. Het inzicht in de resultaten voor deze andere doelen is echter niet volledig, omdat hierover niet hoeft te worden gerapporteerd en effecten op bijvoorbeeld biodiversiteit zich pas op lange termijn voordoen. Daar staat tegenover dat kavelruil ook negatieve effecten kan hebben op de kwaliteit van het landschap, bijvoorbeeld doordat bij de samenvoeging van percelen waardevolle landschapselementen verloren gaan.

\subsection{Concluderend}

De resultaten van de analyse ondersteunen de verwachting dat kavelruilprojecten bijdragen aan de toekomstbestendigheid van de landbouw in de Overijsselse gebieden waar deze projecten zijn uitgevoerd. In de periode 2013-2017 zijn de melkveebedrijven van de in de analyse meegenomen CKO-projecten gemiddeld 10 hectare groter geworden; in de gebieden met gerealiseerde kavelruilen is ongeveer $20 \%$ van deze vergroting bij de huisbedrijfskavel gerealiseerd, in de overige CKO-gebieden is dat ruim $10 \%$.

De kavelruilprojecten hebben dus tot een sterkere vergroting van de huisbedrijfskavel geleid. Ook voor de kavelafstand hebben de kavelruilprojecten tot positieve effecten geleid. De afstand van de veldkavels van melkveebedrijven tot de bedrijfslocatie is in de projectgebieden met ruilingen met gemiddeld $6 \%$ afgenomen, terwijl in de andere CKO-gebieden sprake was van een toename van deze afstand met $2 \%$. In de projectgebieden met ruilingen is eveneens een sterkere vergroting van de veldkavels te constateren. Vooral Rheeze-Rheezerveen valt daarbij op: hier is de gemiddelde omvang van de veldkavels van alle melkveebedrijven in het projectgebied met een halve hectare toegenomen, terwijl de gemiddelde toename in de projectgebieden zonder ruilingen verwaarloosbaar was.

Ook voor de individuele bedrijven is kavelruil in de betrokken projectgebieden gunstig geweest. De berekeningen tonen aan dat de kavelruil op de meeste deelnemende bedrijven heeft bijgedragen aan een versterking van de structuur van het bedrijf. De bewerkingskosten per hectare zijn door de kavelruil afgenomen met gemiddeld 27 euro per hectare per jaar. Bij een gemiddelde bedrijfsoppervlakte van 46 hectare komt dat neer op 1.200 euro per bedrijf per jaar. Daarnaast is in de meeste gevallen een bedrijfsvergroting gerealiseerd, die heeft gezorgd voor een aanzienlijke versterking van de structuur van de bedrijven. Gedurende de beschouwde vijf jaar is de gemiddelde bedrijfsoppervlakte met $12 \%$ toegenomen. Dit percentage is groter dan het landelijk gemiddelde groeipercentage in de melkveehouderij, die over deze periode ongeveer $8 \%$ was. Hoewel de bedrijfsvergroting niet geheel mag worden toegeschreven aan de kavelruil, is het aannemelijk dat de kavelruil wel heeft geleid tot een extra impuls voor bedrijfsvergroting.

In de effectenberekening zijn andere effecten dan die op de bewerkingskosten niet meegenomen. Voorbeelden van andere effecten zijn: het gemakkelijker toepassen van weidegang en gemakkelijkere controle op vee en gewas als de kavels dichter bij de bedrijfsgebouwen liggen. Het is dus aannemelijk dat het eerdergenoemde bedrag van 27 euro per hectare per jaar een onderschatting is. 
Naast deze bijdragen aan de toekomstbestendigheid van de landbouw zijn er naar verwachting ook effecten van kavelruil op de verkeersveiligheid, leefbaarheid, biodiversiteit, waterveiligheid en op het landschap. Deze (verwachte) effecten konden in dit onderzoek niet nader worden onderzocht. 


\section{$4 \quad$ Kavelruil in andere provincies}

\section{$4.1 \quad$ Inleiding}

In dit hoofdstuk bespreken we de aanpak en ervaringen van vier andere provincies met het instrument kavelruil. In onze quickscan zijn de provincies Gelderland, Utrecht, Noord-Holland en Zeeland meegenomen. Deze provincies zijn gekozen, omdat de aanpak die ze hanteren mogelijk inspiratie op kan leveren voor het vervolg van het Programma Landbouwstructuurversterking in Overijssel. Onderwerpen die in deze analyse aan bod komen, zijn: de wijze waarop genoemde provincies kavelruil organiseren en ondersteunen, de uitgangspunten die zij daarbij hanteren, de doelen die zij met kavelruil beogen en de resultaten ervan.

\subsection{Aanpak en ervaringen}

Alle vier provincies uit de quickscan hechten belang aan landbouwstructuurversterking ten behoeve van een economisch sterke en rendabele landbouwsector. Kavelruil is, net als in Overijssel, een belangrijk instrument hiervoor en verdient volgens deze provincies dan ook ondersteuning. De wijze waarop de provincies kavelruil inzetten en ondersteunen verschilt wel sterk per provincie.

\section{Organisatie}

De provincie Zeeland heeft sinds 2012 een eigen kavelruilbureau en een provincie-brede kavelruilcommissie. Het kavelruilbureau wordt bemenst door provinciale ambtenaren ( $3 \mathrm{fte}$ ) en kent een schil van zes zzp'ers die als kavelruilcoördinator worden ingezet in de verschillende deelgebieden van Zeeland. De kavelruilcommissie is een adviescommissie op basis van de Provinciewet en bestaat uit een onafhankelijke voorzitter, drie gebiedsdeskundigen en vertegenwoordigers van het Waterschap, Rijkswaterstaat, Rijksvastgoedbedrijf, gemeenten en Provincie Zeeland. Zij adviseren GS over de concrete kavelruilinitiatieven.

In de provincies Gelderland en Noord-Holland is kavelruil meer op afstand geplaatst van de provincie. Hier zijn separate stichtingen actief die speciaal zijn opgericht om kavelruilprojecten van de grond te tillen en te begeleiden. De in 1962 opgerichte Stichting ter Verbetering van de Agrarische Structuur (STIVAS) in Noord-Holland heeft de langste historie. Onlangs heeft STIVAS haar activiteiten ook uitgebreid naar Flevoland. In Gelderland is sinds 2013 de Stichting Effectief Verkavelen In Gelderland (STEVIG) actief. Net als CKO in Overijssel is dit een samenwerking tussen LTO Noord en Kadaster en eerder DLG. STEVIG kampt momenteel met liquiditeitsproblemen en zit in een proces van opheffing en overdracht van activiteiten. Daarnaast nemen in Gelderland ook andere organisaties - zoals terreinbeherende organisaties, particuliere bureaus en lokale stichtingen voor kavelruil - initiatieven voor kavelruil voor verschillende doeleinden, waaronder landbouwstructuurversterking. In een aantal gebiedsprocessen neemt de provincie Gelderland ook zelf het initiatief voor kavelruil en heeft dan een rol als procesregisseur.

STIVAS en STEVIG hebben in vergelijking met CKO een breder samengesteld bestuur. Het bestuur van STIVAS kent twaalf leden met een onafhankelijke voorzitter en vertegenwoordigers namens de sectoren landbouw, natuur, water en recreatie. Het bestuur van STEVIG biedt plek aan drie vertegenwoordigers van LTO Noord, één vertegenwoordiger namens de waterschappen, één namens de terreinbeherende organisaties en één namens de Gelderse gemeenten. De Stichting heeft een eigen secretariaat. De provincie Gelderland en het Kadaster zijn betrokken als adviseurs van de stichting.

De Provincie Utrecht kent geen organisaties die zich louter richten op het ondersteunen van kavelruil. Kavelruilprojecten worden hier uitgevoerd door de Gebiedscommissie Utrecht-West en de Gebiedscoöperatie O-gen, die actief is in het oostelijk deel van de provincie. Beide organisaties houden zich 
bezig met een scala aan activiteiten op het gebied van plattelandsontwikkeling, waaronder dus ook kavelruil.

\section{Kader 4.1: Integrale kavelruil in het Binnenveld}

Het Utrechtse deel van het Binnenveld kenmerkt zich door veel kleine percelen en een versnipperd eigendom en gebruik. De natuurrealisatie ten weerszijden van het riviertje de Grift komt verder niet goed van de grond. Landbouw en natuur staan al jarenlang tegenover elkaar. In de afgelopen vijftien jaar is meermalen tevergeefs gepoogd middels inzet van kavelruil de agrarische structuur in het gebied te verbeteren en een grondpositie te creëren voor natuurontwikkeling.

In 2015 besluit Gebiedscoöperatie O-gen om een nieuwe poging te wagen, maar dan met een andere aanpak. Belangrijke elementen hierin zijn de inzet van een externe, onafhankelijke kavelruilcommissie, bestaande uit leden met een bestuurlijke achtergrond, zonder directe belangen in het gebied. Ook zijn de doelen en randvoorwaarden van het proces in een bestuurlijk afsprakendocument vastgelegd. Zo spreken provincie Utrecht, gemeente Rhenen, Waterschap Vallei en Veluwe, Staatsbosbeheer, LTO Noord, ANV Binnenveld en Gebiedscoöperatie O-gen af eigenaren en pachters binnen de Natura 2000gebieden voorrang te geven in de toedeling van de kavelruil, waardoor de natuurherstelmaatregelen uit de PAS kunnen worden uitgevoerd. Om dit mogelijk te maken, zegt de provincie toe zo nodig een stukje Natuurnetwerk te zullen ontgrenzen. Verder wordt ervoor gekozen het opdrachtgeverschap voor de kavelruil neer te leggen bij de gemeente Rhenen. Naast aankoop en inzet van provinciale grond als smeermiddel worden ook andere instrumenten ingezet om agrariërs te verleiden. Bijvoorbeeld de belofte van een bestemmingsplanverandering (woonbestemming geven naast een boerderij met opvolger) of via het toepassen van de sloopregeling voor vrijstaande agrarische opstallen.

De aanpak is een succes. Drie jaar na de start wordt op 16 april 2018, met de ondertekening van de ruilakte, het kavelruilproces afgesloten. Het ruilplan kent 36 deelnemers, waarvan 26 agrarische ondernemers, Staatsbosbeheer, de gemeente Rhenen, de provincie Utrecht en nog 7 andere partijen. Er worden 143 percelen geruild met een totale oppervlakte van 290 hectare. Door de ruilingen vergroot ruim de helft van de agrarische deelnemers de huiskavel en neemt het aantal losliggende veldkavels af. Daarnaast kan door de kavelruil de inrichting van een drietal natuurgebieden eindelijk van start en wordt de uitvoering van een maatregel uit het landelijk Programma Aanpak Stikstof (PAS) mogelijk gemaakt. Een deel van de natuuropgave wordt echter nog niet gerealiseerd.

\section{Financiën en grond}

Geen van de provincies uit de quickscan heeft een meerjarig provinciaal programma voor landbouwstructuurversterking met duidelijke prestatiedoelen en een gereserveerd programmabudget. Wel zetten alle provincies POP3-gelden en eigen cofinancieringsmiddelen in voor de ondersteuning van kavelruil en vragen ze een eigen bijdrage van deelnemende grondeigenaren. In Zeeland is 1,5 miljoen euro beschikbaar uit het Europese POP3-budget in de periode 2016-2021, naast de provinciale capaciteit die is ondergebracht in het Kavelruilbureau. In Noord-Holland bedraagt de Europese bijdrage 1,7 miljoen euro in de periode 2016-2021. Voor Utrecht en Gelderland is minder duidelijk welk bedrag zij uit POP3 beschikbaar stellen voor kavelruil en hoeveel uit eigen middelen. Sommige kavelruilprojecten in deze provincies worden alleen met provinciale middelen ondersteund wegens de administratieve last die met een POP3-aanvraag gemoeid is. In Zeeland en Noord-Holland worden de administratieve lasten beperkt door niet per kavelruilproject een POP3-aanvraag te vragen, maar met koepelprojecten te werken (het project Kavelruilbureau Zeeland en het project 'Kavelruil Werkt!' van STIVAS in Noord-Holland).

De eigen bijdrage van grondeigenaren aan proces-, kadaster- en notariskosten loopt flink uiteen per provincie, evenals de berekeningswijze. Zo moeten in Noord-Holland grondeigenaren 75 euro per ingebrachte hectare bijdragen en in Zeeland 200 euro per toebedeelde hectare. In de provincie Utrecht ligt de eigen bijdrage op $1 \%$ van de waarde van de toebedeelde hectares (voor het project Binnenveld kwam dit uit op690 euro per hectare). In Gelderland wordt geen bijdrage gevraagd aan grondeigenaren voor proces-, kadaster- en notariskosten. Voor kavelaanvaardingswerken ligt de eigen bijdrage in alle provincies, net als in Overijssel, op 60\% van de totale kosten en is een maximum gesteld aan de provinciale subsidie.

Net als Overijssel faciliteert Zeeland kavelruil met een strategische ruilgrondbank. Deze wordt samen met het instrument kavelruil als onmisbaar gezien om de doelen op het vlak van natuur-, 
infrastructuur- en landbouwstructuurversterking te realiseren. De Zeeuwse grondbank, die als streefwaarde ongeveer 1200 hectare groot is, wordt voor 800 hectare gefinancierd met provinciaal geld en voor 400 hectare uit het Natuurpakket Westerschelde. Gelderland verstrekt een investeringskrediet voor aankoop van gronden voor landbouwstructuurverbetering, maar onduidelijk is hoe groot dit krediet is. Daarnaast heeft de provincie ruilgrond voor natuurdoelen. In Noord-Holland werkt de provincie op dit moment niet met een grondbank. Alleen in de Vechtstreek heeft de provincie nog een beheergrondbank. Hierin zitten nog gronden vanuit een vroeger programma ('Groene Uitweg'). STIVAS mist de grondbank niet: er is volgens de directeur voldoende aanbod aan grond van de provincie, gemeenten, waterschappen, het Rijksvastgoedbedrijf, Rijkswaterstaat, natuurorganisaties en particuliere eigenaren om aan kavelruil mee te doen. Ook Utrecht heeft geen grondbank. Voor landbouwstructuurversterking worden in deze provincie geen ruilgronden aangekocht. Wel kan de provincie ruilgronden aankopen voor de realisatie van natuurdoelen in kavelruilprojecten. Ook voormalige BBL-gronden kan de provincie inzetten als ruilgrond in kavelruilprojecten als daarmee natuur- en landschapsontwikkeling gerealiseerd wordt. Gronden waarmee geen doelen gehaald kunnen worden, worden verkocht; hiervoor geldt een jaarlijkse taakstelling.

\section{Uitgangspunten}

In alle bestudeerde provincies is vrijwilligheid een belangrijk uitgangspunt. Kavelruil is hierdoor pas een succes als alle partijen er voordeel in zien. De genoemde provincies zetten het instrument wettelijke landinrichting niet meer in, omdat hiervoor het bestuurlijk draagvlak en/of de noodzaak ontbreekt. Wel benut de provincie Utrecht dwingend instrumentarium soms als stok achter de deur om grondeigenaren te bewegen mee te doen aan de kavelruil (zie kader 4.1).

Anders dan in het Overijsselse programma Landbouwstructuurversterking, hanteren Zeeland, NoordHolland en Utrecht niet het uitgangspunt dat initiatieven voor kavelruil vooral uit de agrarische sector komen. Hoewel ook deze provincies hechten aan draagvlak bij de agrarische sector, kunnen ook andere partijen (zoals natuurorganisaties, waterschappen, gemeenten en de provincie) zelf initiatieven nemen voor kavelruil en doen dat ook. Voor draagvlak is volgens betrokkenen uit deze provincies vooral belangrijk dat er gelijkwaardigheid is tussen de verschillende belangen en iedere deelnemer voldoende aan zijn trekken komt. Hiervoor is maatwerk belangrijk en een onafhankelijk opererende kavelruilcoördinator.

Kader 4.2: Groot kavelruilproject gerealiseerd in Wieringermeer

Op 19 februari 2018 passeerde de akte van de grootste kavelruil die STIVAS de afgelopen jaren begeleidde. In de Wieringermeerpolder en op Wieringen ruilde de provincie Noord-Holland, het rijk, NUON en 10 agrariërs onderling een grondoppervlak van 309 hectare. 8 akkerbouwers en 2 veehouders kregen hierdoor grotere, dichterbij gelegen en beter op elkaar aansluitende percelen, waardoor het agrarisch verkeer op de weg afnam. Het zweefvliegveld werd verlengd tot de benodigde lengte van 1200 meter en er ontstond ruimte voor een windpark van NUON.

De uitgangssituatie was uniek. Aanvankelijk was de provincie Noord-Holland van plan met de aanleg van een recreatiemeer en een groot aantal woningen een impuls te geven aan vitaliteit van de Kop van Noord-Holland. Hierdoor zou het voormalige eiland Wieringen weer een eiland worden. Voor de ontwikkeling van het zogenoemde Wieringerrandmeer had de provincie 550 hectare grond verworven. $\mathrm{Na}$ jaren van planvorming werd het plan in 2010 echter afgewezen door Provinciale Staten wegens de gebrekkige financiële onderbouwing.

Hierna stelden betrokken partijen een plan voor agrarische structuurverbetering in het gebied op dat de basis vormde voor de kavelruil. De provincie verkocht in de kavelruil zo'n 110 hectare agrarische grond. STIVAS zette de provinciale gronden uit het voormalige Wieringerrandmeerproject in om de agrarische structuur in dit gebied te verbeteren, in combinatie met natuurrealisatie en opwaardering van het watersysteem.

Naast de inbreng van provinciale gronden, droegen de positieve instelling van de betrokkenen, nauwe samenwerking en een houding van 'elkaar ook wat gunnen' bij aan het succes. Vertraging ontstond doordat het Rijksvastgoedbedrijf nader onderzoek naar de bodemgesteldheid van enkele percelen wilde laten doen. Een oplossing werd gevonden doordat zowel de provincie als het rijk ieder op één plek de sanering van vervuilde grond voor hun rekening nam. 


\section{Doelen}

In de betrokken provincies worden met de inzet van het instrument kavelruil naast

landbouwstructuurversterking ook zo veel mogelijk andere doelen bediend. Zo wil het Kavelruilbureau

Zeeland op integrale wijze maatschappelijke opgaven en beleidsdoelen realiseren. Naast

landbouwstructuurversterking gaat het hierbij om de afronding van het Natuurnetwerk Zeeland waterdoelen, infrastructurele projecten (wegen, rotondes, fietspaden) en het Natuurpakket Westerschelde. Dit zijn niet alleen provinciale doelen, maar bijvoorbeeld ook doelen of wensen van gemeenten, het waterschap, Rijkswaterstaat of particulieren. In het kavelruilproces vindt dan de kruisbestuiving plaats tussen private en publieke doelen. Het aansturen op meerdere doelen vindt plaats door in een zo vroeg mogelijk stadium de verschillende opgaven en wensen te inventariseren en daarop te anticiperen. In de omgeving van bijvoorbeeld een aan te leggen weg kan de grondbank in Zeeland al aan de slag door vast ruilgronden te verwerven.

In Noord-Holland wordt onderscheid gemaakt tussen kleinere, sectorale, kavelruilen tussen gemiddeld vier tot zes agrariërs en zogenaamde 'crossing' kavelruilen, waarmee ook doelen op het gebied van natuur, water, recreatie en infrastructuur worden gerealiseerd en meer eigenaren zijn betrokken (zie kader 4.2). Ook STEVIG in Gelderland maakt onderscheid tussen sectorale projecten en integrale projecten. Bij die laatste ligt het initiatief veelal bij de provincie zelf. De provincie Utrecht ondersteunt voornamelijk integrale kavelruilprojecten.

\section{Resultaten}

Door het Kavelruilbureau Zeeland is er de afgelopen 5 jaar 4.300 hectare vrijwillig geruild. Daarbij waren ruim 600 burgers, ondernemers en overheden betrokken. Naast de verwezenlijking van de diverse provinciale beleidsdoelen zijn er volgens de provincie vele kavels geconcentreerd en dichter bij de bedrijven komen te liggen. Dit heeft voor een betere landbouwstructuur gezorgd en voor een betere verkeersveiligheid door minder landbouwverkeer. In Noord-Holland is in de eerste 3 jaar van de POP3-periode ca. 1.650 hectare geruild, waarmee de doelstelling ruimschoots is overschreden. Van de 2 andere provincies hebben we geen opgaven ontvangen.

\subsection{Concluderend}

Net als Overijssel ondersteunen ook de provincies Gelderland, Utrecht, Noord-Holland en Zeeland kavelruil met subsidies en met inbreng van ruilgrond. Verschillen met de aanpak in Overijssel zijn onder meer het ontbreken van een meerjarig programma voor landbouwstructuurversterking en de meer integrale aanpak van kavelruilprojecten in Gelderland, Utrecht, Noord-Holland en Zeeland. De provincie Zeeland heeft verder een kavelruilbureau dat onderdeel is van de provinciale organisatie en een centrale kavelruilcommissie. In Utrecht is de uitvoering van door de provincie gesubsidieerde kavelruil belegd bij gebiedsorganisaties met een breder takenpakket. Noord-Holland, en tot voor kort ook Gelderland, kennen, net als in Overijssel, wel aparte stichtingen voor de ondersteuning van kavelruil, maar deze hebben een breder samengesteld bestuur en een bredere focus. De provincie Zeeland lijkt met gemiddeld bijna 1000 hectare ruilingen per jaar het succesvolst in de omvang van kavelruil. Succesfactoren zijn het vroegtijdig inventariseren van verschillende belangen en doelen, het actief aankopen van ruilgronden in gebieden waar iets gaat spelen en de combinatie van een provinciaal Kavelruilbureau en in vaste gebieden werkende kavelruilcoördinatoren. 


\section{Kansen voor kavelruil bij toekomstige inrichtingsopgaven}

\section{$5.1 \quad$ Inleiding}

In het landelijk gebied van Overijssel komen verschillende functies zoals landbouw, water, natuur, wonen, recreatie en landschap samen. De interactie daartussen leidt niet vanzelf tot een duurzame inrichting van het landelijk gebied met schoon water, schone lucht en bodem, een rijke natuur, een vitale leefomgeving en een toekomstbestendige economie. Hoewel Overijssel op veel beleidsterreinen stappen heeft gemaakt in het bereiken van duurzaamheidsambities in het landelijk gebied, zijn de resterende opgaven rond klimaat en energie, landbouw en voedselproductie en natuur en biodiversiteit nog steeds complex.

In dit hoofdstuk bespreken we de rol die kavelruil kan spelen bij de aanpak van toekomstige opgaven voor het landelijk gebied in Overijssel. We bouwen hierbij voort op de opgaven die Nieuwenhuizen et al. $^{12}$ richting 2050 onderscheiden op basis van een analyse van het doelbereik bij voortzetting van het huidige beleid en van de nieuwe ontwikkelingen die er op het landelijk gebied van Overijssel afkomen. Het gaat hierbij om (1) het invullen van ruimteclaims die voortkomen uit de klimaat-, landbouw- en energietransitie, (2) zorgvuldig omgaan met grondstoffen en productiefactoren, (3) terugdringen emissies milieubelastende stoffen, (4) realisatie van ruimtelijke kwaliteit en (5) benutten van sociale waarden. Deze opgaven worden eerst kort besproken (par. 5.2), waarna we in gaan op de rol die kavelruil kan spelen bij de aanpak ervan (par. 5.3). We sluiten af met enkele concluderende opmerkingen (par. 5.4).

\subsection{Toekomstige inrichtingsopgaven}

Invullen ruimteclaims die voortkomen uit de klimaat-, landbouw- en energietransitie De druk op de grond in het landelijk gebied van Overijssel blijft naar verwachting tot 2050 onverminderd hoog door (een combinatie van) de volgende factoren:

- De invulling van de energietransitie, met vooral wind, zon en biomassa, zorgt in de toekomst voor grote ruimteclaims in het landelijk gebied. Maatregelen in stedelijke gebieden, zoals maximale benutting van daken voor zonnepanelen, zullen daarvoor niet toereikend zijn.

- De vraag naar grond vanuit de landbouw zelf blijft groot. Als de landbouw meer grondgebonden en in kringlopen gaat werken, zal er voor duurzaam bodembeheer en het zo veel mogelijk sluiten van regionale kringlopen behoefte blijven aan voldoende landbouwgrond.

- Het veranderende klimaat zal ook ruimte vragen voor het opvangen van grote hoeveelheden neerslag en het vasthouden van water, als buffer voor droge periodes.

- Ook in de bodem en ondergrond wordt de vraag naar ruimte voor o.a. drinkwater- en grondstoffenwinning, energie en $\mathrm{CO}_{2}$-opslag groter. Dit vergt een steeds verdergaande afstemming of afweging van vormen van ruimtegebruik in boven- en ondergrond.

De grotere vraag naar grond vanuit diverse functies vraagt om nieuwe vormen van ruimtegebruik in het landelijk gebied door te zoeken naar mogelijkheden voor meervoudig ruimtegebruik, waarbij functies met elkaar gecombineerd worden zonder daarbij schade toe te brengen aan bijvoorbeeld de ondergrond of andere functies. Het gaat hierbij niet alleen om meervoudig ruimtegebruik in fysieke zin, maar bijvoorbeeld ook om verdienmodellen die ervoor zorgen dat functies van elkaar kunnen profiteren. Denk bijvoorbeeld aan combinaties van landbouw en energieproductie of landbouw en waterberging. Op die manier kan ook de druk op de grond op termijn minder worden.

\footnotetext{
${ }^{12}$ W. Nieuwenhuizen, E. Gies en M. van der Heide (2018), Analyse verduurzamingsopgaven landelijk gebied Overijssel richting 2050.
} 


\section{Zorgvuldig omgaan met grondstoffen en productiefactoren}

Op het gebied van grondstoffen en productiefactoren zijn richting 2050 de volgende ontwikkelingen relevant voor Overijssel:

- De Agro \& Foodketen in Overijssel maakt momenteel veel gebruik van grondstoffen en productiefactoren zoals bodem en water. Het sluiten van kringlopen in de keten kan Overijssel minder afhankelijk maken van grondstoffen van elders en draagt bij aan het behoud van bodemvruchtbaarheid en reductie van o.a. broeikasgasemissie en waterverbruik.

- Klimaatverandering speelt een belangrijke rol bij de drinkwatervoorziening in Overijssel. Schaarste aan grond- en oppervlaktewater is op termijn geen ondenkbaar scenario. Bij een toenemende watervraag neemt het belang van zorgvuldig omgaan met water toe. Daarnaast komen grondwaterbronnen onder druk te staan doordat voor de klimaatopgave steeds vaker gekeken wordt naar aardwarmte (warmteopslag onder de grond) en $\mathrm{CO}_{2}$-opslag onder de grond. Beide ontwikkelingen kunnen nadelen hebben voor de winning van grondwater.

- De vraag naar biomassa zal de komende vijftien jaar naar verwachting aanzienlijk stijgen. Naast de traditionele toepassingen van biomassa voor voedsel, bouwmateriaal, papier en karton, zien steeds meer bedrijven kansen om over te schakelen op biomassa als een hernieuwbare en duurzame grondstof voor materialen en chemie.

De opgave die hieruit voortkomt, is om zorgvuldig en zuinig om te gaan met grondstoffen en productiefactoren in het landelijk gebied van Overijssel om daarmee zo min mogelijk afhankelijk te zijn van eindige grondstoffen. De invulling van deze opgave zal veel innovaties vragen. Voor de landbouw in Overijssel zou dit kunnen betekenen dat de ontwikkelingsrichting verschuift van voortdurende verlaging van de kostprijs naar verlaging en recycling van het gebruik van grondstoffen.

\section{Terugdringen emissies milieubelastende stoffen}

Beleidsdoelen voor klimaat, biodiversiteit, (drink)water, bodem en gezondheid in Overijssel kunnen alleen bereikt worden als de emissies van broeikasgassen, nitraat, ammoniak en fosfaat op termijn dalen. Meer specifiek gaat het hierbij om de volgende uitdagingen:

- Het reduceren van de uitstoot van broeikasgassen uit de landbouwsector staat nog maar aan het begin. Tot 2050 zal $80-95 \%$ reductie van die uitstoot ten opzichte van 1990 nodig zijn om de huidige klimaatdoelstellingen te realiseren.

- De stikstofbelasting vanuit de landbouw van veel Overijsselse natuur is ondanks het huidige beleid in 2030 nog meer dan 30\% te hoog.

- De belasting van het grondwater met nitraat is gedaald, maar is in veel gevallen nog te hoog en dat bedreigt nog steeds de toekomstige drinkwatervoorziening in Overijssel.

- Fosfaatuitspoeling uit de bodem en nitraatuitspoeling door overbemesting blijven de komende decennia voor ongeveer een kwart van het oppervlaktewater in Overijssel een te hoge belasting geven (uitgaande van de normen uit de Kaderrichtlijn Water).

De opgave die hieruit voortkomt, is om de urgentie van het terugdringen van emissies van broeikasgassen te combineren met het substantieel verlagen van het gebruik van andere milieubelastende stoffen. Een voorbeeld is het beperken van de uitstoot van broeikasgassen in de veehouderij. Dit kan ook bijdragen aan het verlagen van de stikstofbelasting en daarmee aan het verbeteren van de waterkwaliteit en de biodiversiteit in het landelijk gebied.

\section{Realisatie ruimtelijke kwaliteit}

Het landschap in Overijssel verandert continu en behoud en/of versterking van de kwaliteit van het landschap zijn in het licht van de voorgaande ontwikkelingen niet vanzelfsprekend. Hierbij zijn de volgende factoren aan de orde:

- De kwaliteit van het landschap is een belangrijke vestigingsplaatsfactor voor inwoners en bedrijven en van groot economisch belang voor de vrijetijdsbesteding van recreanten en toeristen. Veel boeren en burgers voelen zich verbonden met het landschap in hun omgeving. Verder draagt een groene omgeving bij aan de gezondheid van mensen. Door klimaatverandering zullen diverse functies in het landelijk gebied zich moeten aanpassen aan grotere weersextremen. Natuur en landbouw moeten robuust en veerkrachtig genoeg zijn om extremen in droge en warme periodes op te kunnen vangen. De natuur moet ook een plek kunnen bieden aan nieuwe soorten die hun intrede 
zullen doen als gevolg van de klimaatverandering. Dit vraagt om ruimtelijke verbindingen van leefgebieden (ook buiten bestaande natuurgebieden) en diversiteit in condities voor die soorten.

- De landbouwproductie in Overijssel zal zich moeten aanpassen aan meer extreme omstandigheden en lage afvoeren in de rivieren. Verder heeft de klimaatverandering invloed op zowel kwalitatieve als kwantitatieve aspecten van de drinkwatervoorziening.

De opgave die hieruit voortkomt, gaat over het vinden van nieuwe manieren om de grote ruimteclaims en het klimaatbestendig maken van Overijssel bij te laten dragen aan de waardevolle kenmerken van het Overijsselse landschap, zoals een gezonde en aantrekkelijke leefomgeving. Op verschillende plekken in Overijssel zullen naar verwachting nieuwe landschappen ontstaan, waarin bestaande kwaliteiten verdwijnen en nieuwe kwaliteiten moeten worden toegevoegd.

\section{Benutten sociale waarden}

De in het voorgaande geschetste ontwikkelingen tot 2050 hebben grote gevolgen voor de dagelijkse leefomgeving en daarmee het leven van de inwoners van Overijssel. De grote uitdaging hierbij is om bij de verduurzaming van het landelijk gebied de betekenis en waarden van de bewoners en bezoekers te benutten. Hierbij spelen de volgende factoren een rol:

- De invulling van de genoemde opgaven zal het landschap van Overijssel veranderen en daardoor botsen met de waarden van (een deel) van de bewoners en bezoekers. Toenemend belang en invloed van niet-agrarische functies geven ook meer kans op meer onderlinge spanningen.

- $\mathrm{Er}$ is nog grote onzekerheid over de haalbaarheid en betaalbaarheid van de hiervoor geschetste opgaven die tot 2050 in het landelijk gebied van Overijssel spelen. Verdienmodellen in de huidige systemen staan onder druk. Alternatieve verdienmodellen zijn nodig, maar kunnen ook leiden tot hogere prijzen voor consumenten, zoals voor voedsel en energie. Het is de vraag of daar voldoende draagvlak voor is.

- De trend is dat mensen meer eigen regie willen over hun eigen leefomgeving, maar ook steeds meer gevraagd worden om daarin zelf het voortouw te nemen. Dit geeft meer ruimte voor eigen initiatief en zelforganisatie en biedt daarmee kansen om ook vanuit burgers en buitenlui een bijdrage te leveren aan de realisatie van de opgaven in het landelijk gebied in Overijssel.

- Solidariteitsprincipes in de samenleving veranderen. Individuen komen losser te staan van bestaande instituties. In plaats hiervan ontstaan nieuwe vormen van solidariteit in zelfgekozen verbanden, waar mogelijk niet iedereen in de samenleving baat bij heeft. Verschillen in de samenleving zullen groeien. Demografische (krimp en vergrijzing) en technologische ontwikkelingen (digitalisering en robotisering) kunnen hierin sturende factoren zijn.

De opgave hierbij is om nieuwe manieren te vinden om sociale en economische waarden van bewoners, bedrijven en bezoekers in het landelijk gebied centraal te zetten bij de invulling van de transities voor klimaat, energie, landbouw en biodiversiteit, zodat de sociale kwaliteit toeneemt.

\subsection{De rol van kavelruil bij toekomstige inrichtingsopgaven}

De geschetste inrichtingsopgaven zijn nog erg globaal en zullen de komende tijd nog verder ruimtelijk uitgewerkt en geconcretiseerd moeten worden. Dan zal ook duidelijk moeten worden hoe kavelruil in combinatie met andere bestaande en nieuwe beleidsinstrumenten ingezet kan worden voor een samenhangende aanpak. Dit gezegd hebbende, zien we al wel een aantal aanknopingspunten voor een eigentijdse inzet van het instrument kavelruil.

Het instrument planmatige kavelruil is de afgelopen jaren primair ingezet voor het verbeteren van de efficiëntie van de landbouwbedrijven in Overijssel. In het licht van de nieuwe en concurrerende ruimteclaims zou het instrument meer ingezet kunnen worden op het realiseren van functiecombinaties, zoals combinaties tussen landbouw en natuur en/of waterbeheer en landbouw en duurzame energie. Waar het bij deze ontwikkelingen vaak om gaat, is dat de juiste boer op de juiste plek zit of dat de juiste functies bij de juiste boer terechtkomen. Zo kan er bijvoorbeeld sprake zijn van de verplaatsing van een weidevogelbedrijf naar een locatie in de buurt van een natuurgebied of 
het toebedelen van weidevogelpercelen aan een boer die kiest voor natuurbeheer doet. Zeker als er nog te schuiven is met functies, kan vrijwillige kavelruil een belangrijke rol spelen in het proces om tot de gewenste inrichting te komen. Hierbij kan ook de inzet van natuurgronden in kavelruilen aan de orde zijn. Als er zowel gronden vanuit de landbouw, de natuurorganisaties als de waterschappen ingezet worden in kavelruilen (en onderling geruild kunnen worden), kan de effectiviteit van de kavelruil in het kader van de gewenste functiecombinaties integrale gebiedsontwikkeling ook toenemen. Daarbij is het belangrijk om het instrument van kavelruil tijdig in te zetten, zodat speelruimte bij de toewijzing van functies aan locaties maximaal benut kan worden.

Kavelruil kan ook een belangrijke rol spelen bij het verminderen van de druk op de grondmarkt, die ontstaat door verschillende ruimteclaims. Als bijvoorbeeld via kavelruil de huiskavels vergroot worden en het aantal veldkavels wordt teruggebracht, neemt de noodzaak voor ondernemers om nieuwe kavels te kopen af. Als er voldoende grond bij huis is, wordt het ook gemakkelijker om in te spelen op maatschappelijke eisen op het gebied van weidegang en het streven naar grondgebondenheid ${ }^{13}$. Vanuit het streven naar kringlooplandbouw biedt het kansen om met kavelruil de totstandkoming van een 'regionaal' bouwplan te ondersteunen, waarmee de eiwitbehoefte van melkveehouderijbedrijven daadwerkelijk in de eigen regio kan worden ingevuld en er zorgvuldiger wordt omgegaan met grondstoffen.

Als het gaat om het terugdringen van de emissies van schadelijke stoffen kan kavelruil in combinatie met bedrijfsverplaatsing een rol spelen bij het 'wegruilen' van intensieve bedrijven uit de buurt van bijvoorbeeld Natura 2000-gebieden, woon- of recreatiegebieden. Op die manier kunnen piekbelastingen van stikstof of fijnstof gereduceerd worden.

Het versterken van de ruimtelijke kwaliteit, is gezien de grote ruimteclaims, een belangrijke uitdaging in Overijssel richting 2050. Kavelruil kan een bijdrage leveren om die kwaliteit te realiseren. Nu is dat nog onvoldoende het geval, omdat het landschap nog onvoldoende wordt meegenomen in ruilplannen. Er moeten dan wel relevante eisen aan de ruilplannen gesteld worden. Daarbij kan bijvoorbeeld gedacht worden aan het realiseren van een bepaalde hoeveelheid landschapselementen bij de verwerving van een bepaalde hoeveelheid grond.

De inzet voor deze samenhangende opgaven brengt met zich mee dat kavelruil in Overijssel breder wordt ingebed, bijvoorbeeld in het omgevingsbeleid en in integrale gebiedsprocessen. Nu staat het instrument te veel op zichzelf, met een eigen programma en eigen organisatievormen. Er is daardoor te weinig prikkel om het in te zetten voor bredere opgaven. In integrale gebiedsprocessen kunnen overheden en stakeholders de geschetste inrichtingsopgaven verder uitwerken en bepalen welke functies op welke plek wenselijk zijn en welke landschappelijke kwaliteit wordt nagestreefd. Vervolgens kan kavelruil in combinatie met de inzet van het Revolving Fund een van de instrumenten zijn die bijdraagt aan het realiseren van de gewenste functiecombinaties, de ruimtelijke kwaliteit en de opgaven waar agrarische ondernemers voor staan, zoals grondgebondenheid, weidegang en kringlooplandbouw.

Ook sociale waarden van deelnemers en niet-deelnemers kunnen meer centraal komen te staan als kavelruil wordt ingebed in integrale gebiedsprocessen. Dat betekent dat de aansturing van de kavelruil verbreed wordt, bijvoorbeeld door kavelruilcommissies een bredere samenstelling te geven en/of burgers en buitenlui op andere manieren actief te betrekken bij inrichtingsprocessen. De 'governance' van kavelruil zou daarmee aangepast moeten worden aan de eisen van de toekomstige samenhangende opgaven in het landelijk gebied.

\footnotetext{
${ }^{13}$ Commissie Grondgebondenheid LTO/NZO (2018). Grondgebondenheid als basis voor een toekomstige melkveehouderij, Den Haag.
} 


\subsection{Concluderend}

In het landelijk gebied van Overijssel komen verschillende functies, zoals landbouw, water, natuur, wonen, recreatie en landschap, samen. Hoewel de provincie Overijssel op veel beleidsterreinen stappen heeft gemaakt in het bereiken van haar duurzaamheidsambities voor het landelijk gebied, blijven er complexe, resterende opgaven rond klimaat en energie, landbouw en voedselproductie en natuur en biodiversiteit bestaan. Richting 2050 staat de provincie voor de volgende uitdagingen:

(1) het invullen van ruimteclaims die voortkomen uit de klimaat-, landbouw- en energietransitie, (2) zorgvuldig omgaan met grondstoffen en productiefactoren, (3) terugdringen emissies van milieubelastende stoffen, (4) realisatie van ruimtelijke kwaliteit en (5) benutten van sociale waarden. Kavelruil kan, in combinatie met andere beleidsinstrumenten, bijdragen aan de aanpak van deze opgaven. Dat betekent wel dat kavelruil in Overijssel breder wordt ingebed in integrale gebiedsprocessen, zodat het kan bijdragen aan meervoudig doelbereik. Nu staat het instrument kavelruil te veel op zichzelf, met een eigen programma en eigen organisatievormen. Er is daardoor te weinig prikkel om het in te zetten voor bredere opgaven en functiecombinaties. In integrale gebiedsprocessen kunnen overheden en stakeholders de geschetste inrichtingsopgaven verder uitwerken en bepalen welke functies op welke plek wenselijk zijn en welke landschappelijke kwaliteit wordt nagestreefd. Kavelruil kan daaraan een belangrijke bijdrage leveren. 


\section{Conclusies en aanbevelingen}

\section{$6.1 \quad$ Inleiding}

De Provincie Overijssel zette met het Programma Landbouwstructuurversterking de afgelopen jaren in op de verbetering van de structuur van de Overijsselse grondgebonden landbouw. Nu het programma is afgelopen, is de vraag: hoe verder? Als input voor de besluitvorming hierover werd Wageningen Research gevraagd een evaluatie uit te voeren van het programma. Hiertoe onderzochten we de werking, resultaten en effecten van het programma alsmede de ervaringen met het instrument kavelruil in andere provincies. Op basis van de bevindingen die staan beschreven in de vorige hoofdstukken trekken we in dit laatste hoofdstuk conclusies en doen we aanbevelingen aan de provincie over de toekomst van het programma en het instrument vrijwillige, planmatige kavelruil.

De opbouw van dit hoofdstuk volgt de onderzoeksvragen uit hoofdstuk 1 . In paragraaf 6.2 trekken we conclusies over de resultaten en effecten van het programma en de gevolgde aanpak. Paragraaf 6.3 gaat over de succes- en faalfactoren bij de uitvoering van het programma. In paragraaf 6.4 bespreken we de conclusies over de aanpak en ervaringen van andere provincies met het instrument kavelruil. In paragraaf 6.5 staan onze aanbevelingen voor de toekomst van het programma en het instrument kavelruil, mede in het licht van de toekomstige opgaven voor het landelijk gebied waar de provincie voor staat.

\subsection{Resultaten en effecten}

In deze paragraaf staat de volgende onderzoeksvraag centraal:

In hoeverre heeft het Programma Landbouwstructuurversterking en de gehanteerde aanpak de gewenste resultaten en effecten opgeleverd in de provincie Overijssel?

Het programma van de provincie en de aanpak van de initiatiefnemers en kavelruilcommissies heeft geresulteerd in vierentwintig projecten. Hiervan zijn twee projecten vroegtijdig gestopt, zeven afgerond en vijftien nog in uitvoering. In deze projecten is in totaal 1.053 hectare geruild. Hiermee is inmiddels volgens de Overijsselse methode 5.505 hectare landbouwstructuurversterking gerealiseerd. In totaal wordt er met de projecten 16.598 hectare landbouwstructuurversterking voorzien. Hiermee wordt in potentie ruimschoots voldaan aan de resultaatdoelstelling van 12.500 hectare landbouwstructuurversterking voldaan, maar wel ruim later dan gepland.

Deze resultaten dragen bij aan de verbetering van de toekomstbestendigheid van de deelnemende bedrijven en de landbouwsector als geheel in de gebieden waar kavelruilprojecten zijn uitgevoerd. Vrijwillige, planmatige kavelruil draagt via de uitruil en omvorming van percelen bij aan verbetering van de verkavelings-situatie op gebiedsniveau. Zo heeft kavelruil in de projectgebieden tot een sterkere huisbedrijfskavelvergroting geleid dan in gebieden zonder ruilingen. Ook voor de vermindering van de kavelafstand tot de bedrijfslocaties hebben de ondersteunde kavelruilprojecten positieve effecten gehad. Melkveebedrijven in de gebieden waar ruilingen zijn uitgevoerd, realiseren een sterkere vergroting van de veldkavels dan in gebieden zonder kavelruil. Deze verbetering in de verkavelingssituatie betaalt zich uit in vermindering van de bewerkingskosten op bedrijfsniveau. Voor de deelnemende bedrijven komt dat neer op gemiddeld 1200 euro per jaar.

Vrijwillige, planmatige kavelruil kan ook positieve effecten hebben op de realisatie van andere maatschappelijke en publieke opgaven, zoals de Ontwikkelopgave Natura 2000/PAS, wateropgaven en landschapskwaliteit. Voor zover bekend, zijn de resultaten en effecten van het Programma Landbouwstructuurversterking op dit vlak beperkt. Er zijn in de afgeronde projecten hooguit enkele 
tientallen hectares vrij gespeeld voor natuurontwikkeling en wateropgaven. De provincie stuurt ook niet actief op bredere inzet van het instrument planmatige kavelruil. Het programma heeft een sectorale doelstelling en CKO en andere initiatiefnemers worden afgerekend op gerealiseerde hectares landbouwstructuurversterking, niet op meervoudig doelbereik. Het is dan ook niet ondenkbeeldig dat er door deze sectorale insteek kansen voor breder doelbereik zijn gemist.

Inmiddels zijn er bij Losser, in Haaksbergen en rond het Boetelerveld wel planmatige kavelruilprojecten gestart die zich naast landbouwstructuurversterking richten op de Natura 2000/PAS-ontwikkelopgave in de betreffende gebieden. Deze kavelruilprojecten vinden plaats in nauwe afstemming met de Natura 2000-projecten in die gebieden. Deze kavelruilprojecten zijn nog niet afgerond; de bijdrage aan meervoudig doelbereik moet daarom nog grotendeels duidelijk worden.

De provincie Overijssel investeerde met het Programma Landbouwstructuurversterking en POP3 ruim 6 miljoen euro in de ondersteuning van vrijwillige kavelruil ten behoeve van een duurzame, concurrerende en toekomstbestendige landbouwsector.

De uitvoering van het programma kende aanvankelijk twee sporen: een prestatieafspraak met CKO en de mogelijkheid van incidentele projectaanvragen van andere partijen. Van deze laatste mogelijkheid hebben vooral gemeenten gebruikgemaakt. Vanaf 2016 is ook POP3 jaarlijks opengesteld voor subsidieaanvragen van individuele kavelruilprojecten. Hierdoor zijn in feite drie regimes naast elkaar ontstaan met elk hun eigen procedures en voorwaarden. Zo komt het onderscheid tussen planmatige en losse kavelruil in de POP3-regeling niet voor. Ook wordt de eigen bijdrage van deelnemende grondeigenaren in POP3 op andere manier berekend dan in het oorspronkelijke programma en stelt POP3 zwaardere eisen aan projectaanvragen en -verantwoording dan het oorspronkelijke programma.

Door tijdens de uitvoeringsperiode te schuiven met middelen van het Programma Landbouwstructuurversterking naar de Uitvoeringsreserve Ontwikkelopgave Natura 2000/PAS en het beschikbaar komen van POP3-middelen voor landbouwstructuurversterking zijn de input-outputrelaties van het programma onhelder geworden. Zo is het onduidelijk of de middelen in de Uitvoeringsreserve Ontwikkelopgave Natura 2000/PAS nog beschikbaar zijn voor planmatige kavelruil. Daarnaast is de outputdoelstelling van het programma niet aangepast aan de verhoging van het budget voor kavelruil met POP3-middelen. Deze onhelderheid maakt scherpe sturing op efficiency van het programma lastig.

De aanpak van CKO en andere initiatiefnemers, zoals gemeenten en Stimuland, vertoont veel overeenkomsten. Alle partijen reageren op wensen en behoeften aan kavelruil uit het gebied, werken nauw samen met een kavelruilcommissie en maken gebruik van de diensten van een kavelruilcoördinator. Op basis van de geïnventariseerde wensen van grondeigenaren werken de betrokken kavelruilcoördinatoren en kavelruilcommissies een of meerdere ruilplannen uit, waarover overeenstemming wordt gezocht met de betreffende grondeigenaren. Het proces wordt meestal binnen twee jaar afgesloten met het ondertekenen van een of meerdere ruilaktes door de deelnemende grondeigenaren bij de notaris.

De provincie heeft zelf geen initiatieven genomen voor planmatige kavelruil in gebieden waar zij inrichtingsopgaven heeft vanuit andere provinciale belangen, zoals Natura 2000. Planmatige kavelruilprocessen bieden volgens de provincie onvoldoende garantie op het volledig en tijdig realiseren van de ontwikkelopgave Natura 2000/PAS. Om grond beschikbaar te krijgen voor de inrichtingsmaatregelen in de Natura 2000-gebieden, geeft de provincie er de voorkeur aan om een-opeen privaatrechtelijke afspraken te maken met de betreffende eigenaren uit het uitwerkingsgebied. Kavelruil komt in beeld als agrariërs als compensatie voor zelfrealisatie geen geld willen, maar grond. Hiervoor probeert de provincie ruilgrond aan te kopen buiten de begrenzing van de Natura 2000gebieden die kan worden geruild met agrariërs binnen de begrenzing. Dit zijn echter meestal losse kavelruilen of reguliere aan- en verkooptransacties die buiten de scope van het programma vallen. 


\subsection{Slaag- en faalfactoren}

In deze paragraaf staat de volgende onderzoeksvraag centraal:

Wat zijn succes- en faalfactoren in de uitvoering geweest?

Belangrijke slaagfactoren voor de totstandkoming en uitvoering van kavelruilprojecten waren: het goed kunnen inspelen op de wensen in het gebied en het bieden van maatwerk. De gebiedskennis en onafhankelijkheid van de kavelruilcoördinator en de kavelruilcommissie waren hierbij cruciaal. Zij moeten het vertrouwen hebben van potentiële deelnemers om tot goede ruilvoorstellen te kunnen komen.

Daarnaast was de aanwezigheid van voldoende ruilgrond bij aanvang van het project van doorslaggevend belang voor het succes van kavelruil. Het Revolving Fund van de provincie is een nuttige faciliteit gebleken om grond die beschikbaar komt tijdens de projectperiode aan te kunnen kopen en in te kunnen zetten als ruilgrond. Het Revolving Fund kent echter ook nadelen die het resultaat van de inzet beperken. Zo schiet de snelheid van handelen van de provincie bij de inzet van het Revolving Fund soms tekort, met als risico dat de grond aan een andere partij wordt verkocht en niet meer kan worden ingezet in het kavelruilproject. Ook de koppeling van de aankooptitel aan een specifiek kavelruilproject beperkt de inzetbaarheid van het Revolving Fund, evenals het niet kunnen aankopen van bedrijfsgebouwen.

In de initiatieffase van projecten was de rol van een gebiedsmanager of -coördinator in de gemeenten die hierover beschikken belangrijk. Deze personen fungeren als loket voor diverse vragen, wensen en plannen van agrarische ondernemers en andere inwoners van het buitengebied. Ook de kansen voor kavelruil kan een gebiedscoördinator zodoende in een vroegtijdig stadium signaleren. Deze activiteiten liggen ten grondslag aan diverse kavelruilinitiatieven in gemeenten als Raalte en Hof van Twente. Voordeel van deze werkwijze, boven die van CKO, is dat deze mensen op meer continue basis kansen voor kavelruil kunnen inventariseren in de gebieden waar ze actief zijn. Nadeel is dat niet alle Overijsselse gemeenten een dergelijke faciliteit financieren.

De programmafinanciering van CKO heeft geholpen om in gebieden waar de gemeente initiatieven voor kavelruil niet actief ondersteunt, toch kavelruilprojecten van de grond te tillen. Het programmabudget gaf CKO bovendien de mogelijkheid om de voordelen van kavelruil actief onder de aandacht te brengen in gebieden met een slechte of matige verkavelingssituatie.

Een integrale aanpak waarin van meet af aan naast landbouwstructuurversterking ook andere doelen in de kavelruil worden meegenomen, was voor een aantal betrokkenen een duidelijke succesfactor. Naarmate er meer deelnemers en belangen participeren, wordt er meer grond ingebracht, ontstaan er meer ruilmogelijkheden en neemt het rendement toe, ook voor de landbouw. Anderen zien vooral risico's van een integrale aanpak. Als niet-landbouwbelangen de overhand krijgen, pakt dat volgens hen negatief uit voor het vertrouwen van boeren in het kavelruilproces en hun bereidheid om deel te nemen.

Bij de deelnamebereidheid van grondeigenaren speelt ondernemerszin een doorslaggevende rol. Het zijn vooral boeren die door willen in de landbouw die deelnemen aan kavelruil.

Ook culturele en sociale factoren spelen een rol, zoals een sterke gehechtheid aan de grond in bepaalde gebieden of een sfeer van het elkaar niet gunnen. Dit beïnvloedt de kansen voor kavelruil negatief.

Het niet goed betrekken van landschap in kavelruil is een potentiële faalfactor. Soms verdwijnen landschapselementen als kavels worden samengevoegd of worden kansen voor landschapsversterking niet benut. Dit kan het draagvlak voor kavelruil bij burgers en buitenlui ondermijnen. 


\subsection{Kavelruil in andere provincies}

In deze paragraaf staat de volgende onderzoeksvraag centraal:

Hoe geven andere provincies uitvoering aan landbouwstructuurversterking? Welke ervaringen hebben zij daarmee opgedaan?

Net als Overijssel ondersteunen ook de provincies Gelderland, Utrecht, Noord-Holland en Zeeland kavelruil met subsidies en met inbreng van ruilgrond. Verschillen met de aanpak in Overijssel zijn onder meer het ontbreken van een meerjarig programma voor landbouwstructuurversterking en de meer integrale aanpak van kavelruilprojecten in Gelderland, Utrecht, Noord-Holland en Zeeland. De provincie Zeeland heeft verder een kavelruilbureau dat onderdeel is van de provinciale organisatie en een centrale kavelruilcommissie. In Utrecht is de uitvoering van door de provincie gesubsidieerde kavelruil belegd bij gebiedsorganisaties met een breder takenpakket. Noord-Holland, en tot voor kort ook Gelderland, kennen, net als in Overijssel, wel aparte stichtingen voor de ondersteuning van kavelruil, maar deze hebben een breder samengesteld bestuur en een bredere focus.

In deze provincies zijn goede ervaringen opgedaan met inzet van vrijwillige kavelruil voor bredere maatschappelijk opgaven. Naast landbouwstructuurversterking gaat het hierbij ook om natuur, recreatie, water en infrastructurele projecten. Initiatieven voor kavelruil komen behalve uit de landbouw ook van andere partijen als natuurorganisaties, waterschappen, gemeenten en de provincie zelf. Cruciale factoren voor succes zijn, net als in Overijssel, de onafhankelijke rol van de kavelruilcoördinator, het bieden van maatwerk en de beschikbaarheid van voldoende ruilgrond als smeermiddel. In Zeeland heeft het aankopen van ruilgrond vooruitlopend op projecten goed gewerkt.

\subsection{Toekomst programma en instrument kavelruil}

In deze paragraaf staat de laatste onderzoeksvraag centraal. Deze luidt:

Welke aanbevelingen zijn er voor een vervolg van het programma op basis van de antwoorden op bovenstaande vragen en toekomstige opgaven voor het landelijk gebied?

Voor de beantwoording van deze vraag gaan we in op drie aspecten:

- De noodzaak van doorgaande ondersteuning van kavelruil voor landbouwstructuurversterking.

- Mogelijke verbeteringen in de uitvoering van het programma.

- De rol die het programma en het instrument kavelruil kunnen spelen bij toekomstige opgaven.

\section{Noodzaak van doorgaande ondersteuning}

Hierbij beperken we ons tot de vraag of er nog steeds een substantiële verkavelingsopgave is in Overijssel. Of deze verkavelingsopgave noopt tot provinciale ondersteuning van kavelruil is een politieke vraag en onder meer afhankelijk van de toekomstige beleidsdoelen en prioriteiten.

Een analyse van de actuele verkavelingssituatie in Overijssel viel buiten onze evaluatieopdracht. Wel is duidelijk dat de ontwikkelingen in de landbouw die ervoor zorgden dat PS in 2012 besloten om kavelruil te ondersteunen, niet wezenlijk zijn veranderd. De schaalvergroting in de landbouw zet onder invloed van ontwikkelingen in markt- en regelgeving nog steeds door. Agrarische bedrijven houden meer dieren en hebben behoefte aan meer grond, mede in het licht van de fosfaatwetgeving en nieuwe eisen ten aanzien van grondgebondenheid. Met name in de melkveehouderij is er behoefte aan grotere huiskavels om de koeien te kunnen blijven weiden en op kosten te besparen. Maar ook minder en grotere veldkavels dichter bij huis dragen bij aan een efficiëntere bedrijfsvoering. Grond die op de markt komt omdat bedrijven stoppen, ligt echter niet altijd gunstig voor de nieuwe eigenaar of gebruiker. Soms lukt het bedrijven om percelen te verwerven die grenzen aan de huiskavel, maar meestal liggen de nieuwe percelen verder weg en wordt het bedrijfsoppervlak wel groter, maar de verkaveling, uitgedrukt in percentage huiskavel, gemiddelde kavelafstand en aantal veldkavels, 
slechter. De verkavelingskaart van het Kadaster $^{14}$ toont dat het merendeel van de gebieden in Overijssel in 2015 matig tot redelijk verkaveld was en slechts een beperkt aantal gebieden goed tot uitstekend.

Aanbeveling 1: Zorg voor een actualisatie van het beeld van de verkavelingssituatie in Overijssel en een goede prognose van de toekomstige ontwikkeling in de huisbedrijfskavelgrootte, aantal veldkavels en kavelafstand op gebiedsniveau.

\section{Verbeteringen in de uitvoering}

Het Programma Landbouwstructuurversterking was, in termen van gerealiseerde hectares, een succes. De Overijsselse methode om dit te berekenen, zegt echter weinig over de daadwerkelijke versterking van de verkavelingssituatie en de bijdrage aan de toekomstbestendigheid van de sector. Daarom hebben wij in deze evaluatie een analyse gedaan van de verbeteringen in huisbedrijfskavel, kavelafstand en aantal veldkavels als gevolg van de uitgevoerde kavelruilprojecten. Dit sluit aan bij de kengetallen die betrokkenen zelf hanteren voor het meten van het resultaat op bedrijfs- en projectniveau.

Aanbeveling 2: Pas de methode voor het meten van de resultaten van kavelruilprojecten aan op basis van de kengetallen die in de praktijk worden gebruikt, dat wil zeggen de gevolgen voor de huisbedrijfskavel, de kavelafstand en het aantal veldkavels van de betrokken ondernemers. Kijk daarbij niet alleen naar de effecten op bedrijfsniveau, maar ook naar de veranderingen in de verkavelingssituatie op gebiedsniveau.

De resultaten van het programma dragen bij aan de toekomstbestendigheid van sector en de deelnemende bedrijven. Zo is er sprake van een verbetering van de verkavelingssituatie op gebiedsniveau als gevolg van de uitgevoerde kavelruilprojecten en aan kostenbesparing voor de deelnemende bedrijven. De resultaten en effecten kunnen op gebiedsniveau nog worden versterkt door het instrument kavelruil in te zetten in gebieden met een aantoonbaar slechte of matige verkavelingssituatie én voldoende belangstelling voor deelname.

Aanbeveling 3: Wees in geografische zin selectiever met de ondersteuning van planmatige kavelruil voor landbouwkundige doelen. Concentreer de inzet in gebieden met een aantoonbaar slechte of matige verkaveling en voldoende belangstelling voor deelname. Wees kritisch op de ondersteuning van projecten die in feite bestaan uit een serie losse kavelruilen.

In de uitvoering van de kavelruilen in Overijsel is een werkbare taakverdeling ontstaan tussen CKO, gemeenten en Stimuland, waarbij CKO vooral actief is in gebieden waar gemeenten zelf geen initiatieven nemen voor kavelruil. CKO ontvangt programmafinanciering; de andere initiatiefnemers projectfinanciering. Afgaande op de vergelijkbare resultaten die de verschillende organisaties boeken, is er geen duidelijke reden (meer) voor dit onderscheid in financiering. Voordeel van projectfinanciering is bovendien dat de initiatiefnemer pas een projectaanvraag indient als er voldoende zekerheid is over het behalen van resultaat. Projectfinanciering past ook beter bij de POP-systematiek.

Aanbeveling 4: Indien de provincie wederom middelen beschikbaar stelt voor de ondersteuning van planmatige kavelruil, verdient het aanbeveling de huidige financieringsstructuur waarbij CKO programmafinanciering ontvangt en andere initiatiefnemers per project subsidie moeten aanvragen te heroverwegen.

De beschikbaarheid van ruilgrond is cruciaal voor het slagen van kavelruilprojecten. Het Revolving Fund van de provincie is een nuttige faciliteit gebleken om grond die beschikbaar komt tijdens de projectperiode aan te kunnen kopen en in te kunnen zetten als ruilgrond, maar de inzetbaarheid kan nog wel worden vergroot.

Aanbeveling 5: Continueer het Revolving Fund en onderzoek de mogelijkheden voor een bredere inzetbaarheid, bijvoorbeeld door vooruitlopend op projecten reeds ruilgrond aan te kunnen kopen.

\footnotetext{
${ }^{14}$ https://www.verkavelenvoorgroei.nl/
} 


\section{Rol Programma en kavelruil bij toekomstige opgaven}

Richting 2050 komt een aantal nieuwe opgaven op het landelijk gebied van Overijssel af. Deze gaan over het opvangen van nieuwe ruimteclaims vanuit de klimaat-, landbouw- en energietransitie, het zorgvuldig omgaan met grondstoffen en productiefactoren, het terugdringen van milieubelastende emissies, het realiseren van ruimtelijke kwaliteit en het inzetten op sociale waarden. Voor de grondgebonden landbouw is het zo veel mogelijk sluiten van kringlopen een nieuwe uitdaging.

Indien de provincie Overijssel ervoor kiest deze opgaven in haar omgevingsbeleid in samenhang op te pakken, ligt het voortzetten van een overwegend sectoraal ingestoken programma voor kavelruil en een sectorale uitvoering niet voor de hand. Hoewel er in de huidige uitvoeringsperiode wel andere doelen zijn bediend, zijn er door de sectorale insteek waarschijnlijk ook kansen gemist om landbouwstructuurversterking te koppelen aan bijvoorbeeld natuurontwikkeling, infrastructuur en recreatie. Doorgaan op de huidige weg brengt ook het risico met zich mee dat de samenleving zich steeds minder herkent in de toepassing van kavelruil, vooral als de uitruil en samenvoeging van percelen ten koste gaan van de kwaliteit van het Overijsselse landschap.

Het instrument vrijwillige, planmatige kavelruil kan wel een nuttige functie blijven vervullen bij de nieuwe opgaven die op het landelijk gebied afkomen. De aanpak van deze nieuwe opgaven gaat immers vaak gepaard gaan met een ruimtelijke herordening van functies en grondgebruik, waarvoor kavelruil kan worden ingezet. In andere provincies zijn er goede ervaringen opgedaan met de inbedding van kavelruil in bredere gebiedsprocessen. Ook kan er voor verdere doorontwikkeling van het instrument kavelruil gekeken worden naar de ervaringen met de meer integrale kavelruilprojecten in Overijssel zelf, zoals rond het Boetelerveld, bij Losser en in Haaksbergen.

Aanbeveling 6: Zorg voor een meer opgavegestuurde inzet van het instrument kavelruil. Dit kan door kavelruil beter in te bedden in het provinciale omgevingsbeleid en in integrale gebiedsprocessen waarin de toekomstige opgaven van het landelijk gebied in samenhang worden uitgewerkt door gebiedspartijen.

Aanbeveling 7: Evalueer de meer integrale kavelruilprojecten rond het Boetelerveld, bij Losser en in Haaksbergen en leer hiervan ten behoeve van de doorontwikkeling van het instrument kavelruil.

Een meer opgavegestuurde aanpak brengt ook met zich mee dat de inzet van het instrument vrijwillige, planmatige kavelruil beter kan worden afgewogen tegen andere uitvoeringsinstrumenten van het omgevingsbeleid van de provincie. Gezien de omvang en de complexiteit van de nieuwe opgaven verdient ook wettelijke landinrichting, mogelijk in een vernieuwde vorm, betrokken te worden bij deze instrumentenkeuze. Een andere optie is om vrijwillige kavelruil minder vrijblijvend te maken, bijvoorbeeld door vooraf overeenstemming te bereiken over gemeenschappelijke doelen, spelregels en randvoorwaarden. Ook biedt het centraal stellen van de integrale opgave betere aanknopingspunten voor het zoeken van effectieve combinaties van kavelruil met andere beleidsinstrumenten.

Aanbeveling 8: Weeg de voor- en nadelen van vrijwillige, planmatige kavelruil af tegen andere instrumenten om functies op de goede plek te krijgen en zoek naar effectieve combinaties van kavelruil met andere instrumenten.

Aanbeveling 9: Maak bij complexe opgaven vrijwillige kavelruilprocessen minder vrijblijvend door te werken met een bestuurlijk afsprakenkader op gebiedsniveau waarin doelen, spelregels en randvoorwaarden worden geborgd en laat dit dan leidend zijn bij de uitvoering van de kavelruilen.

Een meer integrale inzet van het instrument kavelruil kan ten slotte worden ondersteund door aanvragen voor subsidiëring vanuit gebieden te toetsen aan een brede set criteria.

Aanbeveling 10: Toets als subsidievertrekker aanvragen voor vrijwillige kavelruil op criteria voortkomend uit het omgevingsbeleid en de integrale gebiedsopgaven. Naast landbouwstructuurversterking kan het hierbij gaan om de bijdrage aan landschappelijke, ecologische, cultuurhistorische en/of recreatieve betekenis van het landschap van het gebied en de betrokken percelen. 


\title{
Bijlage 1 Respondenten
}

\author{
Algemeen \\ Herman Arentsen \\ Provincie Overijssel \\ Anja ter Beek \\ Gemeente Twenterand \\ Tjerk Elzinga \\ LTO Noord \\ Gréanne Feenstra \\ Oud-medewerker Provincie Overijssel \\ Sjors van der Graaf \\ Provincie Overijssel \\ Seine Grefelman \\ Stimuland \\ Gerrit Tuten \\ LTO Noord Salland \\ Gerrit Jan van der Veen \\ Stichting Coördinatiepunt Kavelruil \\ Martin Verbeek \\ Stichting Coördinatiepunt Kavelruil
}

\section{Focusgroep Kavelruil Boetelerveld}

Vincent Breen

Gemeente Raalte

Cor Bosch

Kavelruilcoördinator

Gerko Hopster

Projectmanager, Pratensis

Jan Meijerink

André Pelgröm

Stephan Rientjes

Lid kavelruilcommissie, deelnemende agrariër

Gerrit Tuten

Waterschap Drents Overijsselse Delta

Deelnemende agrariër

Voorzitter kavelruilcommissie

\section{Focusgroep Kavelruil Hof van Twente}

Johan Baak

Seine Grefelman

Wilco Pasman

Erik Steen

Herman Veltkamp

Jan Zandvoort
Voorzitter kavelruilcommissie

Kavelruilcoördinator, Stimuland

Gemeente Hof van Twente, voormalig gebiedsmanager

Waterschap Vechtstromen

Deelnemende agrariër

Rentmeester Landgoed Weldam

\section{Focusgroep Kavelruil Rheeze Rheezerveen}

Jan Bouwhuis

Robert Jan Fontein

Henri Hutten

Erik Pullen

Albert van der Veen

Gerrit Jan van der Veen

Martin Wiltink

Teun Wolbink

\section{Gelderland}

Gerko Hopster

Adri Kromwijk

\section{Noord-Holland}

Erwin van den Berg

Stefan Melis

\section{Utrecht}

Ilse van den Berg

Jaap Floor

\section{Zeeland}

Peter Koppejan

Bas van 't Westeinde
Deelnemende agrariër

Provincie Overijssel

Deelnemende agrariër

Lid kavelruilcommissie, deelnemende agrariër

Deelnemende agrariër

Stichting Coördinatiepunt Kavelruil

Kadaster

Voorzitter kavelruilcommissie, deelnemer agrariër

STEVIG

Provincie Gelderland

\section{STIVAS}

Provincie Noord-Holland

Provincie Utrecht

Gebiedscoöperatie O-GEN

Provincie Zeeland

Kavelruilcoördinator Zuid- en Noord-Beveland 


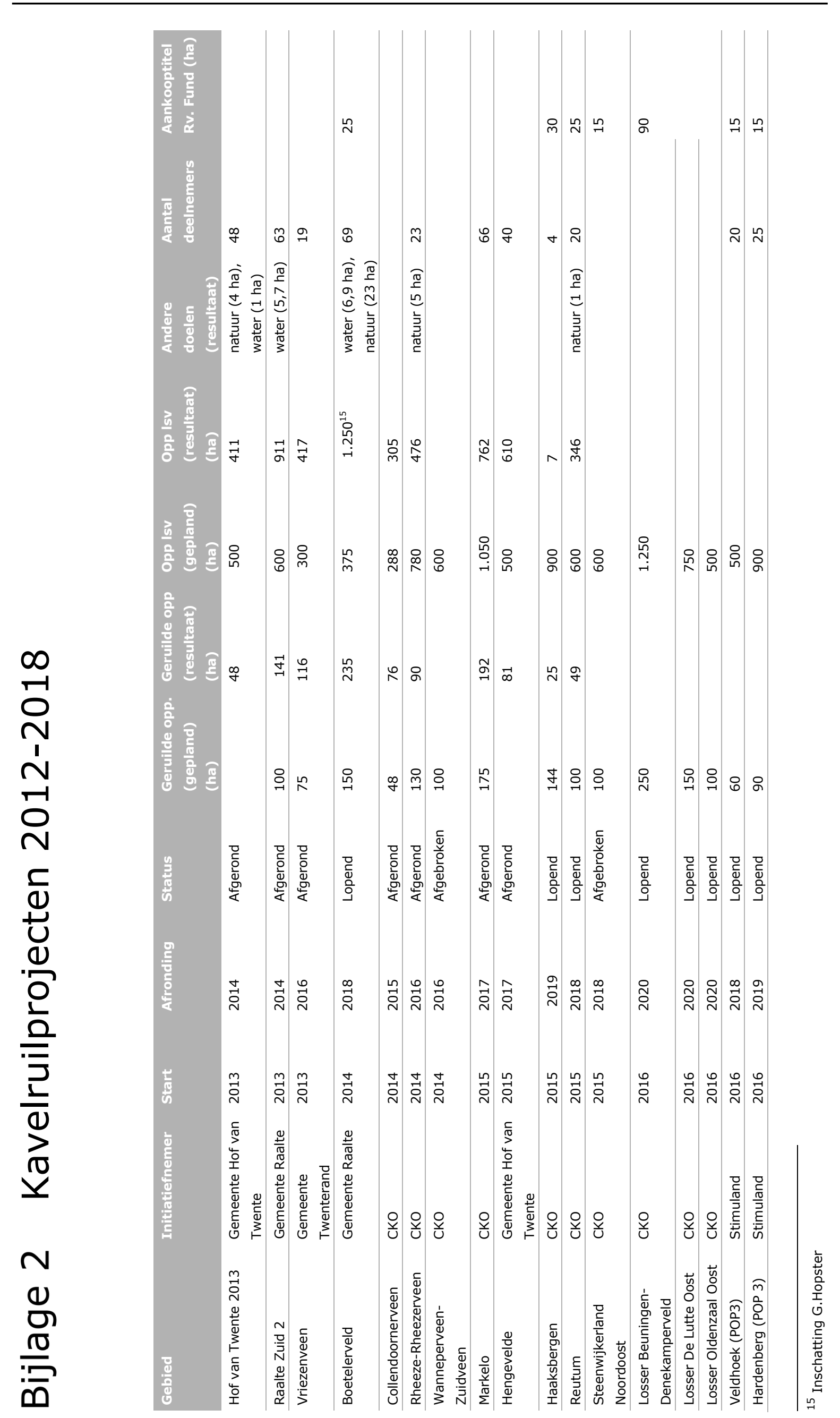




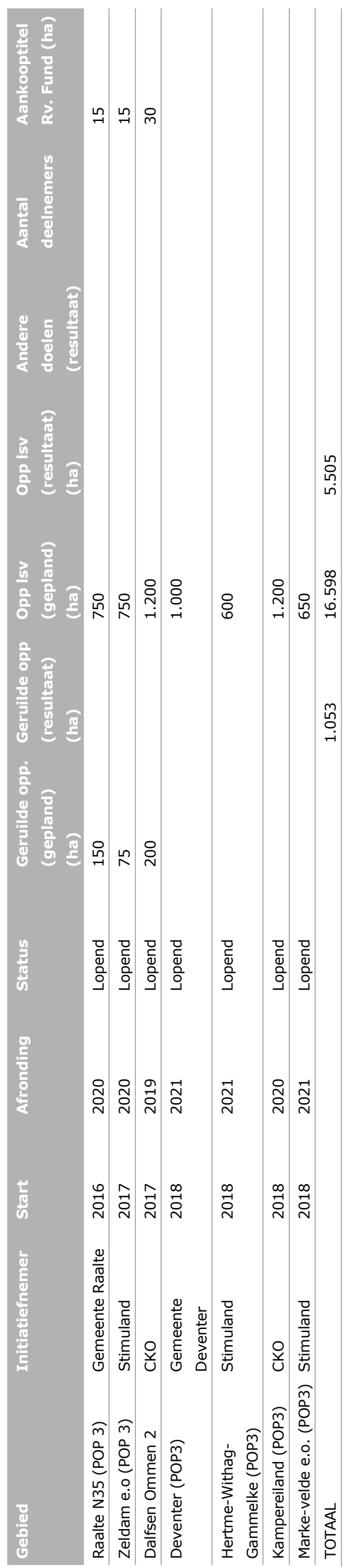

50 | Wageningen Environmental Research Rapport 2941 


\section{Bijlage 3 Effecten landbouwstructuur}

\section{B3.1 Inleiding}

In een aantal gebieden is als gevolg van de ontginningsgeschiedenis in Overijssel een slechte verkaveling ontstaan. Verder verandert de verkaveling vooral door ontwikkelingen in de bedrijfsstructuur. Doordat jaarlijks 2-3\% van de landbouwbedrijven stopt, ontstaat er ruimte voor blijvende bedrijven om in bedrijfsoppervlakte te groeien. Soms lukt het bedrijven om percelen te verwerven die grenzen aan de huiskavel, maar meestal liggen de nieuwe percelen verder weg en wordt het bedrijfsoppervlak wel groter, maar de verkaveling, uitgedrukt in percentage huiskavel, gemiddelde kavelafstand en aantal veldkavels slechter.

Het doel van de planmatige vrijwillige kavelruilprojecten is om binnen een bepaald gebied zodanige ruilingen van gronden te realiseren dat alle bedrijven erop vooruitgaan en daarmee de toekomstbestendigheid van de sector wordt versterkt. Daarom zijn bij de bepaling van de verkavelingssituatie alle (melkvee)bedrijven in het gebied meegenomen. Dit wijkt af van veel gangbare projectrapportages, waarbij alleen de verbeteringen in de verkavelingssituatie van bedrijven die hebben deelgenomen aan de kavelruil worden meegenomen. De gronden buiten de kavelruilgebieden zijn buiten beschouwing gelaten.

Bij verbetering van de verkavelingssituatie gaat het op de eerste plaats om een vergroting van de huiskavel. Een grote huiskavel is vooral van belang bij melkveebedrijven: zij hebben daarmee meer mogelijkheden om het grasland te gebruiken voor beweiding door het melkvee. Daarnaast kan de huiskavel ook van belang zijn bij bedrijven met intensieve teelten, waarbij sprake is van intensief management en veel bewerkingen voor bepaalde gewassen. Een korte afstand tot de veldkavels is voor alle bedrijfstypen van belang: er gaat dan minder tijd en energie verloren met het verkeer van en naar de kavels. Concentratie van percelen in minder veldkavels leidt tot minder tijd- en energieverlies doordat minder transporten tussen bewerkingen nodig zijn.

\section{B3.2 Aanpak en methode}

Om de effecten van kavelruilprojecten te kunnen vaststellen, zijn in principe de verkavelingskenmerken nodig van de situatie voor en na de uitvoering van de kavelruilprojecten in vergelijking met gebieden waarin (nog) geen kavelruilprojecten hebben plaatsgevonden:

- Aandeel huisbedrijfskavel per bedrijf; dit is gedefinieerd als de percelen, die een bedrijf in gebruik heeft en tezamen een kavel vormen, die grenst aan het erf met de bedrijfsgebouwen (huiskavel), inclusief de gebruikspercelen die een kavel vormen aan de overzijde van een lokale weg, grenzend aan de huiskavel (en die daarmee ook bereikbaar zijn voor beweiding).

- Kavelafstand over de weg (eventueel onderverdeeld in verhard, onverhard, water).

- Aantal veldkavels per bedrijf; een veldkavel is een aaneengesloten stuk grond dat een bedrijf in gebruik heeft, bestaande uit één of meer gewaspercelen, die onderling zijn verbonden en bereikbaar en niet van elkaar worden gescheiden door brede waterlopen, (spoor)wegen of percelen van een ander.

In Overijssel is het merendeel van de landbouwbedrijven een melkveebedrijf en omdat voor dit bedrijfstype de huisbedrijfskavelgegevens voor 2013 reeds beschikbaar waren, is de keuze gemaakt om onze analyse te beperken tot de melkveebedrijven.

Daarnaast is bv. ook de waterhuishouding van de percelen van belang; deze moet idealiter zo optimaal mogelijk zijn: niet te droog en niet te nat, maar in de praktijk is enige variatie wenselijk, 
zodat er bij verschillende weersituaties toch een goede gewasproductie kan worden behaald. Dit aspect is niet meegenomen bij deze analyse.

Het oppervlak huiskavel en het aantal kavels werden tot 2008 opgevraagd in de jaarlijkse landbouwtelling van het CBS, maar nu niet meer. In het kader van 'Verkavelen voor groei' heeft het Kadaster een verkavelingsindex ontwikkeld. Deze index is echter voor eenheden bepaald, die niet ruimtelijk gekoppeld zijn aan de gebieden van de planmatige kavelruilprojecten. Daarom is in dit project een GIS-analyse uitgevoerd op de basisregistratie percelen (BRP), waarmee de huisbedrijfskavels en de veldkavels zijn bepaald, inclusief de afstanden van de veldkavels over de weg.

Voor het aandeel huisbedrijfskavel was vanuit een voorgaand onderzoeksproject naar beweidingsmogelijkheden van melkveebedrijven in Nederland wel een bestand beschikbaar met het aandeel huiskavel per melkveebedrijf in $2013^{16}$. Daarbij is voor de perceelsituatie anno 2013 het aandeel van de huisbedrijfskavel bepaald. Dit is ongeveer aan het begin van de evaluatieperiode. In de aanpak 'Verkavelen voor groei' van LTO en het Kadaster ${ }^{17}$ is weliswaar ook de huiskavel bepaald, maar ontbreekt de bepaling van de huisbedrijfskavel (de kavels grenzend aan de huiskavel), die voor de bedrijfsvoering meer waarde heeft dan een veldkavel, die niet grenst aan de huiskavel. Verder sluiten de gebiedsgrenzen van deze kaart niet aan bij de grenzen van de projectgebieden.

Met de GIS-analyse is ook de huisbedrijfskaveloppervlakte voor 2017 bepaald, zodat de ontwikkeling in de tijd zichtbaar wordt en een vergelijking gemaakt kan worden tussen plangebieden waarin ruilingen hebben plaatsgevonden en plangebieden waarin dat nog niet is gebeurd. Het landsdekkende onderzoek met de huisbedrijfskavelsituatie van 2013 geeft ook de mogelijkheid om de situatie in Overijssel van 2013 te vergelijken met de rest van Nederland. Om de verkavelingssituatie binnen een gebied weer te geven, worden alle huisbedrijfskavels bij elkaar opgeteld en gerelateerd aan de gesommeerde bedrijfsoppervlakte van de melkveebedrijven in het gebied. Dit leidt tot een totaalbeeld voor het gebied, waarin grote bedrijven meer invloed hebben op het eindresultaat dan de kleine bedrijven.

Via de GIS-analyse zijn van de melkveebedrijven ook het aantal en de omvang van de veldkavels bepaald: de groepen gewaspercelen, die tezamen een kavel vormen. Dit is gedaan voor de jaren 2013 en 2017; hierbij is 2013 gebruikt, omdat voor dat jaar de huisbedrijfskavels al bepaald waren, wat de eerste stap is om de veldkavels te bepalen. Bij de bepaling van deze kavels is uitgegaan van een maximale afstand van $10 \mathrm{~m}$ tussen de aangrenzende gewaspercelen. Bij een afstand van meer dan $10 \mathrm{~m}$ tussen twee (groepen) percelen worden het 2 kavels.

Vervolgens zijn eveneens met behulp van GIS de kavelafstanden bepaald: de kortste afstand over de weg van de bedrijfslocatie naar de veldkavels. De bedrijfslocaties zijn vastgelegd in het GIABbestand. ${ }^{18}$ Voor het bepalen van deze afstanden is gebruikgemaakt van het nationaal wegenbestand (NWB), versie 2018. Door gebruik te maken van de actuele wegensituatie, wordt de ontwikkeling van de kavelafstand gerelateerd aan de huidige wegensituatie (inclusief de aanleg van nieuwe wegen). Dit is een ingewikkelder bepaling dan een hemelsbrede afstandsberekening die in eerste instantie was toegepast, maar het doet meer recht aan de werkelijkheid, waarin de aanwezige wegen gebruikt worden om de veldkavels te bereiken. Over de verbinding van de kavel aan de weg, het zogenaamde kavelontsluitingspunt, was helaas geen informatie beschikbaar, zodat daarvoor steeds het punt op de weg is genomen dat het dichtst bij het middelpunt van de veldkavel ligt. Ook is geen rekening gehouden met eventueel transport over water; dit zou het rekenwerk een stuk ingewikkelder maken, terwijl dit in Overijssel meestal niet nodig is. Om de gemiddelde kavelafstand in een gebied te bepalen, wordt een maximum van $5 \mathrm{~km}$ toegepast om te voorkomen dat ver weg gelegen percelen het gemiddelde te veel beïnvloeden. Als kavels erg ver liggen, is de kans ook groter dat de bewerkingen niet vanuit de bedrijfslocatie plaatsvinden, maar bv. via een loonwerker. Vervolgens wordt de gemiddelde afstand bepaald en gewogen voor het oppervlak van de veldkavel, zodat grote veldkavels (waarvoor ook meer transporten nodig zijn) zwaarder meetellen dan kleine.

\footnotetext{
${ }^{16}$ Van den Pol-van Dasselaar, A., P.W. Blokland, T.J.A. Gies, M.H.A. de Haan, G. Holshof, H.S.D. Naeff, A.P. Philipsen (2015) Beweidbare oppervlakte en weidegang op melkveebedrijven in Nederland. Wageningen, Wageningen UR (University \& Research centre).

${ }^{17}$ https://www.verkavelenvoorgroei.nl/verkaveling

${ }^{18}$ Gies, T.J.A., J. van Os, R.A. Smidt, H.S.D. Naeff \& E.C. Vos (2015) Geografisch Informatiesysteem Agrarische Bedrijven (GIAB); Gebruikershandleiding 2010. Wettelijke Onderzoekstaken Natuur \& Milieu, Wageningen.
} 


\section{B3.3 Kenmerken betrokken projecten}

Van de kavelruilprojecten in Overijssel waren van de CKO-projecten begrenzingen beschikbaar, die het mogelijk maken om van het plangebied de verkavelingssituatie voor en na de ruilingen te bepalen. Daarom is de analyse beperkt tot de CKO-projecten.

In tabel B3.1 zijn de kenmerken van de in de analyse meegenomen CKO-projecten in de periode 2012-2017 weergegeven. Verschillende projecten lopen ook door in 2018, maar recentste gegevens komen uit 2017. Er zijn twee kolommen met geruild oppervlak: de geplande oppervlakte en de gerealiseerde oppervlakte tot 2017. Vervolgens is het totale oppervlak van het gebied vermeld, de oppervlakte die is opgegeven via de basisregistratie van gewaspercelen (BRP) en het oppervlak in het gebied dat hoort bij de bedrijven in het gebied. Dat laatste is ook vermeld als percentage van de totale BRP-oppervlakte. Meestal is ongeveer 70-90\% van de percelen in gebruik bij bedrijven binnen het gebied. De overige BRP-percelen zijn in gebruik bij bedrijven buiten het gebied; daarnaast is een deel van de landbouwgrond in gebruik bij particulieren, die niet verplicht zijn om hun percelen op te geven bij de BRP. Ten slotte is in de tabel ook het percentage geruilde grond opgenomen ten opzichte van het oppervlak gewaspercelen van bedrijven binnen het gebied. Voor projecten met geruilde hectares in de periode tussen 2012 en 2017, mogen in principe positieve effecten verwacht worden op de verkavelingskenmerken. Deze projecten zijn in de tabel met een schaduwkleur gemarkeerd.

In 2017 waren de projecten Rheeze en Collendoornerveen afgerond en Markelo en Reutum (groten)deels; in deze gebieden mag over de periode 2012-2017 in principe een verbetering van de verkaveling verwacht worden (of een kleinere verslechtering dan in de andere gebieden). Hiervan zouden de positieve effecten vooral in Collendoornerveen zichtbaar moeten zijn, omdat daar de meeste grond is geruild: $33 \%$ van de grond van de bedrijven binnen het project; in RheezeRheezerveen is dat slechts 5\%. Bij Markelo en Reutum zijn tot 2017 voor 6\% van het oppervlak van bedrijven binnen het gebied ruilingen gerealiseerd. Gemiddeld over alle CKO-projecten is gepland dat ongeveer $7 \%$ van de grond wordt geruild.

In de andere projecten zijn in 2017 nog geen ruilingen gerealiseerd, en dus ook geen positieve effecten van kavelruil te verwachten. Ze staan in de tabel, omdat ze de vergelijkingsbasis vormen voor de projecten waar de ruilingen al wel gerealiseerd zijn.

Tabel B3.1 Kenmerken van CKO projecten en gebieden in de periode 2012-2017.

\begin{tabular}{|c|c|c|c|c|c|c|c|c|c|}
\hline $\mathrm{Nr}$ & Naam & $\begin{array}{l}\text { Status } \\
2017\end{array}$ & $\begin{array}{r}\text { Ruiling } \\
\text { plan (ha) }\end{array}$ & $\begin{array}{r}\text { Ruiling } \\
\text { realisatie } \\
\text { (ha) }\end{array}$ & $\begin{array}{r}\text { Tot opp } \\
\text { gebied } \\
(\text { ha })\end{array}$ & $\begin{array}{l}\text { BRP } \\
\text { opp }\end{array}$ & $\begin{array}{l}\text { Tot opp } \\
\text { bedr. }\end{array}$ & $\begin{array}{l}\% \text { proj. } \\
\text { bedrijf }\end{array}$ & $\begin{array}{r}\% \\
\text { Ruiling }\end{array}$ \\
\hline 24 & $\begin{array}{l}\text { Zuidveen } \\
\text { Wanneperveen }\end{array}$ & Afgebroken & 0 & 0 & 1880 & 1495 & 1039 & $69 \%$ & $0 \%$ \\
\hline 28 & Markelo & Uitvoering & 147 & 192 & 4890 & 3779 & 3299 & $91 \%$ & $6 \%$ \\
\hline 32 & Reutum & Uitvoering & 100 & 49 & 1360 & 968 & 803 & $70 \%$ & $6 \%$ \\
\hline 33 & Kampereiland & Verkenning & 150 & 0 & 3000 & 3837 & 3681 & $89 \%$ & $0 \%$ \\
\hline 37 & Haaksbergen N18 & Uitvoering & 200 & 0 & 2640 & 1918 & 1641 & $80 \%$ & $0 \%$ \\
\hline 41 & Collendoornerveen & Afgerond & 76 & 76 & 600 & 450 & 232 & $51 \%$ & $33 \%$ \\
\hline 42 & $\begin{array}{l}\text { Beuningen } \\
\text { Denekamperveld }\end{array}$ & Uitvoering & 250 & 0 & 3055 & 2114 & 1855 & $89 \%$ & $0 \%$ \\
\hline 43 & De Lutte Oost & Uitvoering & 150 & 0 & 2200 & 1275 & 1069 & $74 \%$ & $0 \%$ \\
\hline 44 & Oldenzaal Oost & Uitvoering & 100 & 0 & 3377 & 1790 & 1378 & $84 \%$ & $0 \%$ \\
\hline Gen & eld & & 136 & & 3023 & 2284 & 1888 & $78 \%$ & \\
\hline
\end{tabular}




\section{B3.4 Resultaten}

\section{Huisbedrijfskavel}

Het aandeel huisbedrijfskavel voor de gebieden van de CKO-projecten is weergegeven in tabel B3.2a. Hierin staat eerst het totaal bedrijfsoppervlak van de melkveebedrijven, vervolgens de uitsplitsing in oppervlakte huiskavel, aangrenzende huiskavels en veldkavels. Daarmee is vervolgens het percentage huisbedrijfskavel bepaald. Het gemiddeld huisbedrijfskavel (huiskavel inclusief kavels die grenzen aan de huiskavel) bedraagt $73 \%$ van de totale bedrijfsoppervlakte. De gebieden Markelo en Reutum liggen daar met ruim 60\% duidelijk onder, maar Collendoornerveen en Rheeze Rheezerveen zitten in 2013, voordat de ruilingen gerealiseerd zijn, al op het gemiddelde. Opvallend is het gebied Kampereiland, dat zonder ruilingen al op 93\% huisbedrijfskavel zit. De verwachting is dat door het toepassen van de kavelruilprojecten het aandeel huisbedrijfskavel van met name de melkveebedrijven verder vergroot kan worden (zie tabel B3.2b).

In de landelijke studie naar beweidingsmogelijkheden voor melkveebedrijven $2013^{19}$ bleek dat de huisbedrijfskavels in de provincies Overijssel, Gelderland en Brabant het kleinst zijn van Nederland. Gemiddeld in Nederland in 2013 was het bedrijfsoppervlak van melkveebedrijven 49 hectare, waarvan 24 hectare huiskavel en 6 hectare aangrenzende kavels, waarmee een gemiddelde huisbedrijfskavel van 30 hectare wordt behaald; daarmee is het gemiddelde huisbedrijfskavel $61 \%$. Opvallend is dat alle CKO-projecten boven dit percentage liggen. Kijken we echter naar de omvang van de huisbedrijfskavel in de CKO-projecten, dan blijkt dat deze gemiddeld 25 hectare bedraagt, bij een bedrijfsoppervlakte van gemiddeld 34 hectare. Dat is beide duidelijk onder het landelijk gemiddelde.

Tabel B3.2a Aandeel huisbedrijfskavel van melkveebedrijven in 2013 in de CKO-projectgebieden.

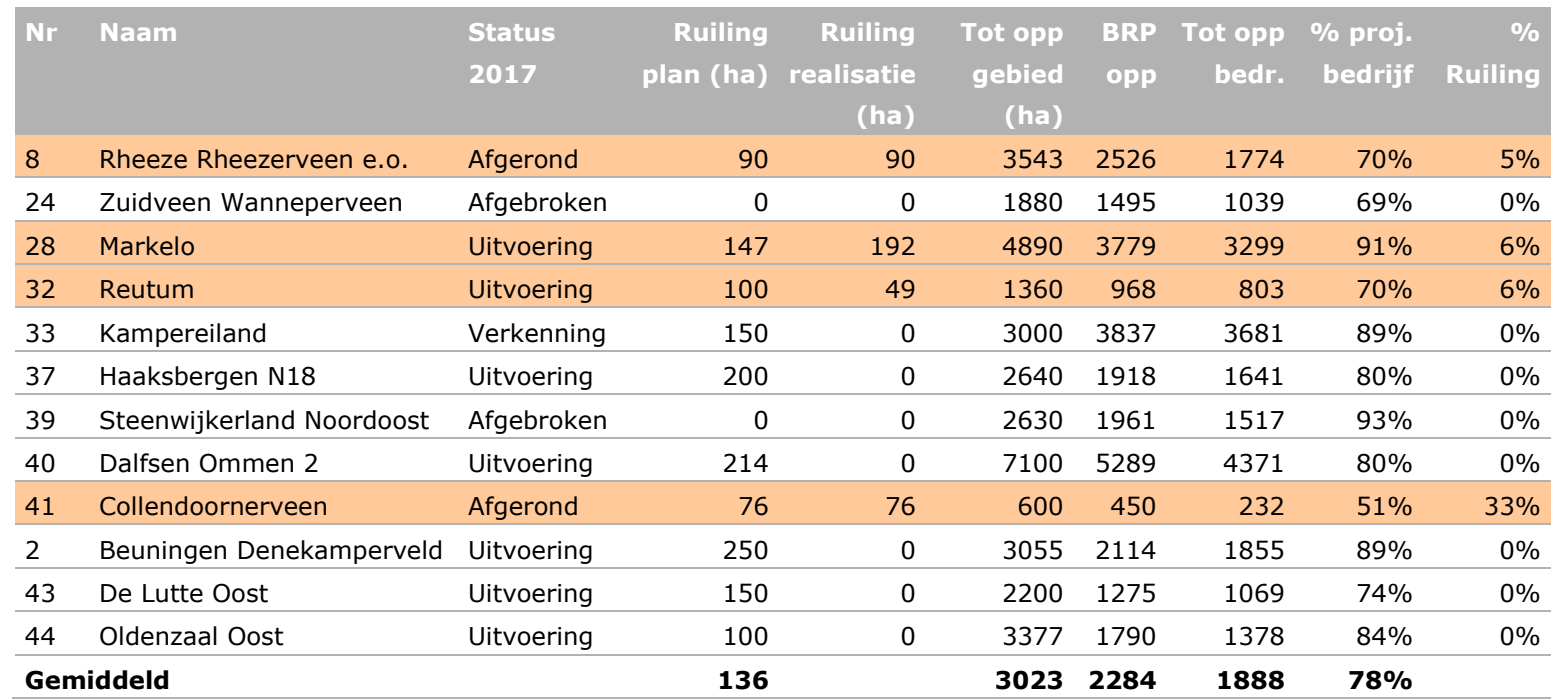

In tabel B3.2b is de huiskavelbepaling van de melkveebedrijven in de projectgebieden in 2017 opgenomen en vergeleken met de situatie in 2013. Het blijkt dat in alle gebieden de gemiddelde bedrijfsoppervlakte van de melkveebedrijven flink is toegenomen, overeenkomend met ca. $30 \%$ van het bedrijfsoppervlak in 2013. De ontwikkeling van de bedrijfshuiskavel is veel minder sterk geweest, waardoor het percentage huisbedrijfskavel is afgenomen. In de gebieden waar ruilingen gerealiseerd zijn, is de bedrijfshuiskavel met gemiddeld 2,3 hectare toegenomen; in de overige CKO-gebieden met 1,3 hectare. In de gebieden met gerealiseerde kavelruilen is de afname in percentage huisbedrijfskavel iets kleiner dan in de overige gebieden. Opvallend is het gebied Collendoornerveen, waar het grote aandeel geruilde grond heeft geleid tot een toename van de gemiddelde huisbedrijfskavel met 10 hectare. We kunnen concluderen dat de schaalvergroting in de melkveehouderij bijdraagt aan een flinke afname van het aandeel bedrijfshuiskavel. Door het

\footnotetext{
${ }^{19}$ Van den Pol-van Dasselaar, A., P.W. Blokland, T.J.A. Gies, M.H.A. de Haan, G. Holshof, H.S.D. Naeff, A.P. Philipsen, 2015. Beweidbare oppervlakte en weidegang op melkveebedrijven in Nederland. Wageningen, Wageningen UR (University \& Research centre) Livestock Research, Livestock Research Rapport 917. http://edepot.wur.nl/362949
} 
toepassen van kavelruilprojecten kan deze teruggang beperkt worden en kan in sommige situaties een flinke toename van huiskavels gerealiseerd worden.

Tabel B3.2b Aandeel bedrijfshuiskavel van melkveebedrijven in 2017 in de CKO-projecten, in vergelijking met de situatie in 2013.

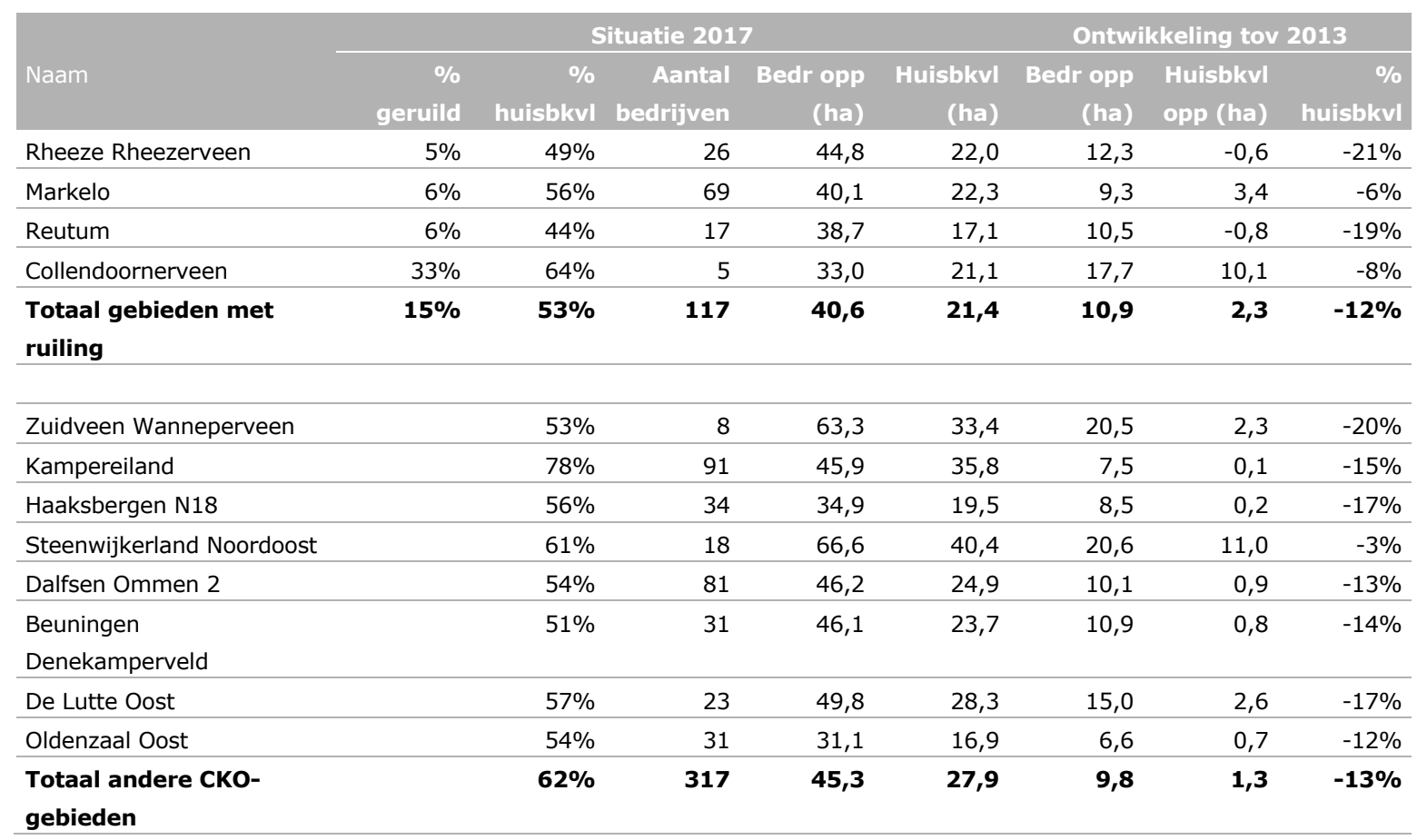

\section{Kavelafstand}

In tabel B3.3 is de ontwikkeling van de perceelafstand weergegeven van de velkavels. In de gebieden waar nog niet geruild is, is de afstand met $2 \%$ toegenomen. Gezien de ontwikkeling in het bedrijfsoppervlak (ruim $30 \%$ erbij) is dat een beperkte toename. In de gebieden met ruilingen blijkt een afname van de gemiddelde veldkavel afstand gerealiseerd, vooral in Rheeze-Rheezerveen en Reutum. Dit betekent dat de kavelruilingen met het oog op verkleining van de kavelafstand effectief zijn geweest. Bij Collendoornerveen lijkt vooral ingezet te zijn op vergroting van de huiskavel, waardoor de gemiddelde afstand van alle percelen waarschijnlijk wel is verminderd, maar de afstand over de weg voor de percelen op de resterende veldkavels nauwelijks is verkleind.

Tabel B3.3 Ontwikkeling van de gemiddelde kavelafstand in km over de weg van melkveebedrijven in de CKO-projectgebieden.

\begin{tabular}{|c|c|c|c|c|c|}
\hline \multirow[b]{2}{*}{ Naam } & \multirow[b]{2}{*}{$\%$ geruild } & \multirow[b]{2}{*}{ Kvlafst 2013 (km) } & \multirow[b]{2}{*}{ Kvlafst 2017} & \multicolumn{2}{|c|}{ Ontw kvlafst tov 2013} \\
\hline & & & & Kvlafst (km) & Kvlafst $\%$ \\
\hline Rheeze - Rheezerveen & $5 \%$ & 1,89 & 1,73 & $-0,16$ & $-8 \%$ \\
\hline Reutum & $6 \%$ & 1,70 & 1,51 & $-0,19$ & $-11 \%$ \\
\hline Collendoornerveen & $33 \%$ & 2,08 & 2,03 & $-0,05$ & $-2 \%$ \\
\hline Zuidveen Wanneperveen & & 1,83 & 2,17 & 0,34 & $19 \%$ \\
\hline Kampereiland & & 4,12 & 3,90 & $-0,22$ & $-5 \%$ \\
\hline Haaksbergen N18 & & 1,91 & 2,19 & 0,28 & $14 \%$ \\
\hline Steenwijkerland Noordoost & & 1,95 & 2,11 & 0,17 & $8 \%$ \\
\hline Oldenzaal Oost & & 2,79 & 2,59 & $-0,20$ & $-7 \%$ \\
\hline Totaal andere CKO gebieden & & 2,62 & 2,68 & 0,07 & $2 \%$ \\
\hline
\end{tabular}




\section{Aantal veldkavels}

In tabel B3.4 is de ontwikkeling van het aantal veldkavels en de gemiddelde veldkaveloppervlakte voor de melkveebedrijven in projectgebieden weergegeven. Het blijkt dat het gemiddelde veldkaveloppervlak in de gebieden die worden voorbereid, in de periode 2013-2017 niet is veranderd. Wel is er gemiddeld ongeveer één veldkavel bijgekomen, als onderdeel van het proces van schaalvergroting. In de gebieden waar wel ruilingen zijn gerealiseerd, is de toename van het aantal kavels iets minder en worden de kavels gemiddeld iets groter. De ruilingen hebben dus een positief effect op de concentratie van percelen in kavels gehad. Vooral in Rheeze-Rheezerveen is dat effect zichtbaar: de kaveloppervlakte is hier het meest toegenomen.

Tabel B3.4 Ontwikkeling gemiddeld aantal veldkavels en gemiddelde kaveloppervlakte van veldkavels van melkveebedrijven in de CKO-projectgebieden.

\begin{tabular}{|c|c|c|c|c|c|c|c|}
\hline \multirow{3}{*}{ Naam } & \multirow{3}{*}{$\begin{array}{r}\% \\
\text { geruild }\end{array}$} & \multicolumn{2}{|c|}{2013} & \multicolumn{2}{|c|}{2017} & \multicolumn{2}{|c|}{ Ontwikkeling veldkavels } \\
\hline & & aantal & Kav opp & Aantal & Kav opp & Aantal & Kav opp (ha) \\
\hline & & kav/bedr & (ha) & kav/bedr & (ha) & kav & \\
\hline Markelo & $6 \%$ & 3,59 & 3,74 & 3,91 & 3,96 & 0,33 & 0,22 \\
\hline Reutum & $6 \%$ & 2,80 & 4,06 & 3,18 & 4,35 & 0,38 & 0,28 \\
\hline Totaal gebieden met ruiling & $15 \%$ & 2,67 & 3,91 & 3,30 & 4,19 & 0,63 & 0,28 \\
\hline Zuidveen Wanneperveen & & 2,74 & 4,91 & 3,63 & 5,19 & 0,89 & 0,28 \\
\hline Kampereiland & & 0,49 & 6,05 & 0,69 & 6,31 & 0,20 & 0,25 \\
\hline Beuningen Denekamperveld & & 3,72 & 4,40 & 4,71 & 4,65 & 0,99 & 0,25 \\
\hline De Lutte Oost & & 4,04 & 3,42 & 3,96 & 3,46 & $-0,09$ & 0,03 \\
\hline Oldenzaal Oost & & 4,79 & 3,01 & 5,55 & 3,08 & 0,76 & 0,07 \\
\hline Totaal andere CKO-gebieden & & 2,97 & 4,50 & 3,77 & 4,59 & 0,80 & 0,08 \\
\hline
\end{tabular}

\section{B3.5 Reflectie op methode}

Het evalueren van effecten van kavelruilprojecten blijkt geen eenvoudige klus. De eerste reden is dat goede kengetallen ontbreken. Met het oog op beperking van administratieve lastendruk zijn vragen over de verkaveling de afgelopen jaren niet meer opgenomen in de jaarlijkse landbouwtelling. Deze kunnen wel bepaald worden vanuit de beschikbare BRP-gegevens, deels geautomatiseerd, maar deels zijn handmatige controles nodig, waardoor het een tijdrovende stap is. Het is aan te bevelen om in elk geval de vraag naar huisbedrijfskavel met enige regelmaat toch op te nemen in de jaarlijkse landbouwtelling.

Tweede factor is de autonome ontwikkeling. In de vijfjaarlijkse periode die geëvalueerd is, hebben niet alleen de kavelruilprojecten plaatsgevonden, maar is ook sprake van een gestage ontwikkeling in bedrijfsomvang: de grond van gestopte bedrijven wordt overgenomen door 'blijvende' bedrijven. Meestal leidt dit tot verslechtering van de verkaveling, doordat de nieuwe percelen niet grenzen aan de bestaande huiskavel of veldkavels. De verbeteringen van de ruilingen worden daarom deels tenietgedaan door toename van het bedrijfsoppervlak, waardoor het lastig is om onderscheid te maken tussen effecten van de autonome ontwikkeling en de kavelruil. 


\section{B3.6 Conclusie}

Wat betreft de omvang van de huisbedrijfskavel is eerst de huisbedrijfskavelsituatie binnen de CKOprojecten vergeleken met de rest van Nederland. Daaruit blijkt dat het aandeel huisbedrijfskavel van de melkveebedrijven in de CKO-projecten weliswaar groter is dan in de rest van Nederland, maar dat het bedrijfsoppervlak en het huisbedrijfskaveloppervlak beide een stuk onder het gemiddelde liggen, wat betekent dat deze bedrijven in Overijssel op dit punt duidelijk een concurrentienadeel hebben. In de periode 2013-2017 zijn de melkveebedrijven in de CKO-projecten gemiddeld 10 ha groter geworden; in de gebieden met gerealiseerde kavelruilen is ongeveer $20 \%$ van deze vergroting bij de huisbedrijfskavel gerealiseerd, in de overige CKO-gebieden is dat ruim $10 \%$. De kavelruilprojecten hebben dus tot een sterkere huisbedrijfskavelvergroting geleid.

Voor de kavelafstand hebben de kavelruilprojecten duidelijk tot positieve effecten geleid. De afstand van de veldkavels van melkveebedrijven in de projectgebieden met ruilingen is met gemiddeld $6 \%$ afgenomen, terwijl in de andere CKO-gebieden sprake is van een toename van $2 \%$.

Wat betreft het aantal veldkavels voor de melkveebedrijven in de projectgebieden blijkt een sterkere vergroting van de veldkavels in de projectgebieden met ruilingen. Vooral Rheeze-Rheezerveen valt daarbij op, waarbij de gemiddelde omvang van de veldkavels met een halve ha is toegenomen. Bij de andere projectgebieden is dat gemiddeld 0,3 ha, wat overeenkomt met $7 \%$ van het gemiddelde kaveloppervlak. 


\section{Bijlage 4 Bedrijfseconomische effecten}

\section{B4.1 Inleiding}

Het doel van kavelruil is verbetering van de bedrijfsstructuur, waardoor vooral de interne logistiek wordt geoptimaliseerd. Dit wordt bewerkstelligd door (1) zo veel mogelijk de percelen onderling te verbinden zonder gebruik te hoeven maken van de openbare weg (vergroting van de huiskavel) en (2) de bereikbaarheid van de percelen te verbeteren (verkleinen van de afstand van de percelen tot de bedrijfsgebouwen). De verwachting is dat deze verbetering in de bedrijfsstructuur van aan kavelruil deelnemende bedrijven zich zal doorvertalen in financiële voordelen voor de ondernemer. Dit wordt in de onderstaande bedrijfseconomische analyse getoetst.

\section{B4.2 Aanpak}

In de analyse is eerst de bedrijfsstructuur van deelnemende bedrijven voor de kavelruil vergeleken met die na de kavelruil. Daarbij zijn op bedrijfsniveau de ontwikkelingen in het aandeel van de huiskavel en in de afstand van tot de veldpercelen tussen 2013 en 2017 onderzocht op basis van de Basis Registratie Percelen (BRP). Vervolgens zijn de financiële effecten van deze ontwikkelingen gekwantificeerd. In dit project zijn deze beperkt tot de bewerkingskosten, inclusief de rijtijden van en naar de percelen.

Op melkveebedrijven kan verbetering van de bedrijfsstructuur ook leiden tot meer mogelijkheden voor beweiding. Omdat hierover geen specifieke informatie beschikbaar was en omdat het niet goed mogelijk is hier een algemene rekenregel voor te ontwikkelen, is dit aspect buiten beschouwing gelaten.

\section{B4.3 Methode}

\section{Selectie van betrokken bedrijven}

In de analyse zijn bedrijven uit vier CKO-projecten met ruilingen en drie afgeronde projecten van ander initiatiefnemers betrokken in de periode 2012-2017. Zie voor de kenmerken van deze projecten tabel B4.1.

Tabel B4.1 Kenmerken van de in de analyse betrokken kavelruilprojecten.

\begin{tabular}{|c|c|c|c|c|c|}
\hline Gebied & Initiatiefnemer & $\begin{array}{l}\text { oppervlakte } \\
\text { projectgebied } \\
\text { in ha }\end{array}$ & $\begin{array}{r}\text { geruilde } \\
\text { hectares in ha }\end{array}$ & $\begin{array}{l}\text { opp Isv in } \\
\text { ha }\end{array}$ & $\begin{array}{l}\text { aantal } \\
\text { deelnemers }\end{array}$ \\
\hline Rheeze-Rheezerveen & CKO & 3543 & 90 & 476 & 24 \\
\hline Markelo & CKO & 6108 & 192 & 762 & 73 \\
\hline Collendoornerveen & CKO & 300 & 76 & 305 & \\
\hline Reutum & CKO & 1430 & 49 & 346 & 20 \\
\hline Vriezenveen & Twenterand & & 116 & 417 & \\
\hline Hof van Twente & Gemeente Hof van Twente & & 48 & 400 & 48 \\
\hline Hengevelde & Gemeente Hof van Twente & & 81 & 610 & 40 \\
\hline
\end{tabular}

De gebruikte databron is de BRP. Hiermee is in principe de verkavelingssituatie op bedrijfsniveau te duiden. De betreffende zeven projecten zijn gestart tussen 2013 en 2015 en afgerond tussen 2014 en 2017. Voor de betrokken bedrijven wordt de bedrijfssituatie vergeleken in 2017 ten opzichte van 2012. 
De bedrijven zijn geselecteerd aan de hand van de volgende kenmerken:

- Deelname aan een of meer van de betreffende projecten.

- Bedrijfsoppervlakte groter dan 10 hectare. Voor kleinere bedrijven is het voordeel moelijker te duiden. Vaak betreft dit geen landbouwbedrijven, maar particulieren met enige grond.

- Meer dan 1 hectare toedeling genoten. Hiermee worden bedrijven uitgesloten die vrijwel alleen maar grond hebben afgestaan, zonder dat de bedrijfsstructuur is versterkt. Vaak zijn dit bedrijven in afbouw.

- Vindbaar in het BRP-bestand. In enkele gevallen bleek het niet mogelijk de 'ruiler' te vinden. Waarschijnlijk gaat dit in de meeste gevallen om particulieren en zijn dus voor dit onderzoek niet interessant.

- Volgbaar door de tijd. In een aantal gevallen was het niet mogelijk de bedrijfsgegevens van 2012 en 2017 aan elkaar te koppelen. Dat komt omdat het RVO-nummer aan persoon gekoppeld is in plaats van aan bedrijf. Bedrijfsopvolging leidt bijvoorbeeld tot verandering van het RVO-nummer. In de meeste gevallen is het alsnog gelukt om de RVO-nummers te koppelen door middel van de adresgegevens. Dit bleek echter niet altijd te lukken.

- Melkveebedrijf. Het blijkt dat de overgrote meerderheid (>80\%) van de deelnemers melkveebedrijven zijn. De andere bedrijven zijn zeer divers (akkerbouw, vleesvee, varkens, gemengd), waardoor het moeilijk is om over deze bedrijven conclusies te formuleren.

Na selectie op bovengenoemde kenmerken resteren 51 bedrijven waarop de evaluatie is toegepast.

\section{Kwantificering van relevante indicatoren}

Uit de BRP zijn per geselecteerd bedrijf en per perceel de volgende relevante perceelgegevens geselecteerd en gekwantificeerd:

- Oppervlakte: voor bepaling van de totale bedrijfsomvang en het aandeel van de huiskavel.

- Geteeld gewas: de voordelen van verbetering van de kavelstructuur verschilt per gewas.

- De afstand van de individuele percelen tot het hoofdbedrijfsgebouw om de invloed van transportafstanden te bepalen.

\section{Berekening financiële voordelen van kavelruil}

Roelofs $^{20}$ heeft de basis gelegd voor het modelmatig berekenen van de financiële effecten van verkaveling. Het Kadaster heeft deze berekeningen overgenomen en in 2017 geüpdatet met de loonwerk- en machine- en arbeidsnormen uit KWIN 2012 en toegepast op de verkavelingssituaties. De resultaten bestaan uit de bewerkingskosten per hectare voor verschillende gewassen bij de verschillende grootteklassen en verkavelingssituaties. De rekenmethode is vastgelegd in de applicatie Pergrobeko, versie 5.

De applicatie geeft een gedetailleerde berekening van het effect van verkaveling op de kosten van brandstofverbruik, arbeid (gewaardeerd tegen 25 euro per uur) en de loonwerkkosten. De effecten zijn beschikbaar voor grasland, onderscheiden in huiskavel en veldkavel, en voor snijmais.

Voor deze gewassen zijn de bewerkingskosten berekend bij verschillende perceelafstanden en perceelgroottes met behulp van Pergrobeko. Vervolgens is regressieanalyse gebruikt om door deze uitkomsten een continue lijn te kunnen trekken.

\section{Pragmatische oplossingen voor ontbrekende/onvolledige gegevens}

De benodigde gegevens voor de uit te voeren modelberekening waren soms niet volledig. In tabel B4.2 staat per knelpunt vermeld hoe hiermee is omgegaan.

\footnotetext{
${ }^{20}$ Roelofs, P.F.M.M. (2010) Invloed van perceelgrootte op arbeidsbehoefte voor veldwerkzaamheden in de melkveehouderij, Beschrijving en onderbouwing van rekenmodel 'PergroBeko'. Praktijkonderzoek Plant \& Omgeving; Randwijk.
} 
Tabel B4.2 Oplossingen voor ontbrekende en/of onvolledige gegevens.

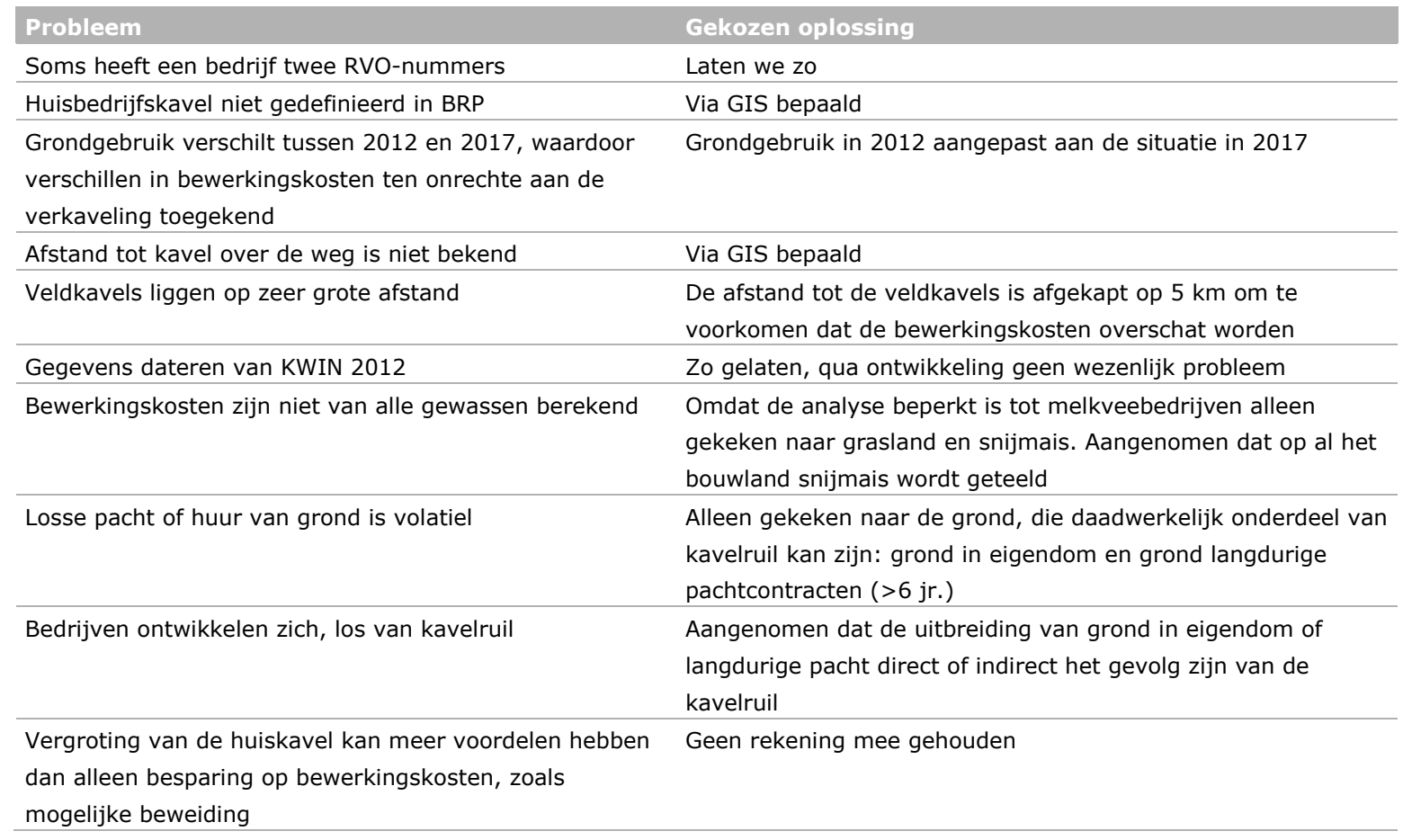

\section{B4.4 Resultaten}

In totaal zijn 51 bedrijven in de analyse meegenomen die aan de selectiecriteria voldoen. In tabel B4.3 zijn de gemiddelde veranderingen in een aantal indicatoren van de bedrijven weergegeven.

Tabel B4.3 Fysieke bedrijfsindicatoren met betrekking tot kavelruil, gemiddeld over de geselecteerde bedrijven.

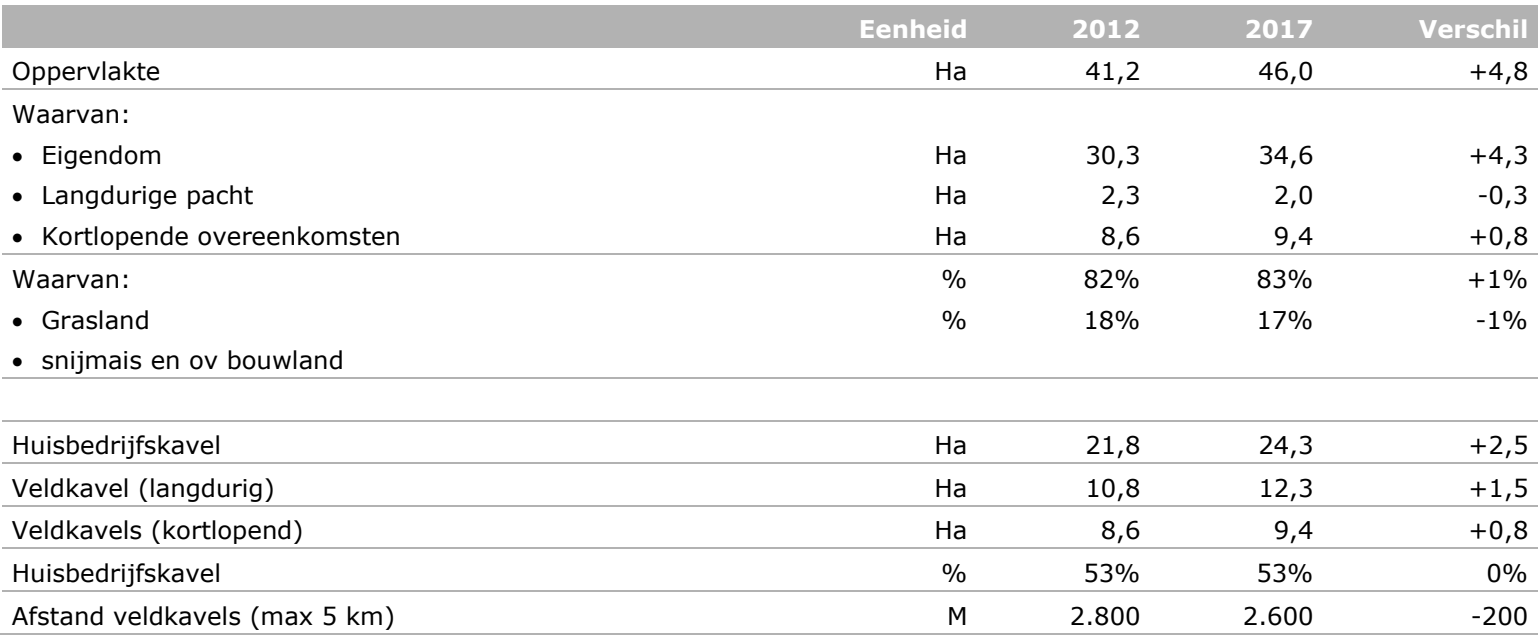

Tabel B4.3 laat zien dat de gemiddelde oppervlakte van de geanalyseerde melkveebedrijven in de beschouwde periode is toegenomen van 41,2 hectare naar 46 hectare. Dit is vooral gerealiseerd door grondaankoop. De hoeveelheidpacht- en huurgrond is gemiddeld genomen niet veel veranderd. Wel heeft een verschuiving plaatsgevonden van langdurige pacht (reguliere pacht, erfpacht en geliberaliseerde pacht met een looptijd van meer dan zes jaar) naar kortlopende pacht en vergelijkbare huurvormen. Voor de berekening van de financiële effecten zijn alleen de ontwikkelingen meegenomen in de hoeveelheden grond in eigendom en langdurige pacht. Kortlopende pacht- en huurgrond is namelijk geen onderdeel van vrijwillige kavelruil. 
De huisbedrijfskavel is groter geworden, maar het percentage huisbedrijfskavel is niet veranderd. De gemiddelde afstand van de veldkavels tot het bedrijfsgebouw is iets afgenomen.

Tabel B4.4 Financiële bedrijfsindicatoren met betrekking tot kavelruil, gemiddeld over de geselecteerde bedrijven.

\begin{tabular}{|c|c|c|c|c|}
\hline & Eenheid & 2012 & 2017 & Verschil \\
\hline Bewerkingskosten (bedrijfsniveau) & Euro/bedrijf & 53.800 & 58.800 & +5.000 \\
\hline Bedrijfsoppervlakte & $\mathrm{Ha}$ & 41.2 & 46.0 & +4.8 \\
\hline
\end{tabular}

Uit tabel B4.4 blijkt dat de kavelruil gemiddeld tot een positief financieel effect te hebben geleid. Dit is becijferd op 27 euro per hectare per jaar. Bij een gemiddelde bedrijfsoppervlakte van 46 ha komt dat neer op 1.200 euro per bedrijf per jaar. Dit bedrag betreft uitsluitend het effect van vermindering van bewerkingskosten.

Tabel B4.5 Spreiding van het financiële effect van kavelruil over de bedrijven (in euro/ha).

\begin{tabular}{lr} 
Nadeel van meer dan 50 euro/ha & Percentage van de bedrijven \\
\hline Nadeel van nul tot 50 euro/ha & $10 \%$ \\
\hline Voordeel van nul tot 50 euro per ha & $15 \%$ \\
\hline Voordeel van 50 tot 100 euro per ha & $40 \%$ \\
\hline Voordeel van 100 tot 150 euro per ha & $15 \%$ \\
\hline Voordeel van meer dan 150 euro per ha & $10 \%$ \\
\hline
\end{tabular}

In tabel B4.5 is de spreiding aangegeven. In een aantal gevallen blijkt de situatie in 2017 tot hogere bewerkingskosten per hectare te leiden dan in 2012. Dit is op het eerste gezicht niet logisch, gezien het doel van kavelruil. Toch is er een aantal verklaringen, zoals (1) grondtransacties, die onafhankelijk van de kavelruil zijn gedaan en leiden tot verslechtering van de gemiddelde resultaten per hectare, (2) percelen, die ten onrechte als veldkavel zijn aangemerkt, (3) bedrijven die in het kader van bedrijfsopvolging zijn gesplitst en (4) aanleg van wegen tussen 2012 en 2017, waardoor de huiskavel is doorsneden.

Op driekwart van de bedrijven die tussen 2012 en 2017 aan kavelruilprojecten hebben deelgenomen, is de situatie in 2017 aantoonbaar gunstiger dan in 2012. Het financiële voordeel kan in individuele gevallen oplopen tot meer dan 150 euro per hectare bedrijfsoppervlakte.

\section{B4.5 Conclusie}

De berekeningen tonen aan dat de kavelruil op de meeste deelnemende bedrijven heeft bijgedragen aan een versterking van het bedrijf. De bewerkingskosten per hectare zijn daardoor afgenomen met 27 euro per hectare per jaar.

Daarnaast is een bedrijfsvergroting gerealiseerd, die heeft gezorgd voor een aanzienlijke versterking van de bedrijven. Gedurende de beschouwde vijf jaar is de gemiddelde bedrijfsoppervlakte met $12 \%$ toegenomen. Dit percentage is groter dan het landelijk gemiddelde groeipercentage in de melkveehouderij, die over deze periode ongeveer 8 was. Het is zeer aannemelijk dat de kavelruil heeft geleid tot een extra impuls voor bedrijfsvergroting.

In de effectenberekening zijn andere effecten dan die op de bewerkingskosten niet meegenomen. Voorbeelden van andere effecten kunnen zijn: het gemakkelijker toepassen van weidegang en gemakkelijkere controle op vee en gewas als de kavels dichter bij de bedrijfsgebouwen liggen. 
Wageningen Environmental Research Postbus 47

6700 AA Wageningen

T 0317480700

www.wur.nl/environmental-research

Wageningen Environmental Research Rapport 2941

ISSN 1566-7197
De missie van Wageningen University \& Research is 'To explore the potential of nature to improve the quality of life'. Binnen Wageningen University \& Research bundelen Wageningen University en gespecialiseerde onderzoeksinstituten van Stichting Wageningen Research hun krachten om bij te dragen aan de oplossing van belangrijke vragen in het domein van gezonde voeding en leefomgeving. Met ongeveer 30 vestigingen, 5.000 medewerkers en 10.000 studenten behoort Wageningen University \& Research wereldwijd tot de aansprekende kennisinstellingen binnen haar domein. De integrale benadering van de vraagstukken en de samenwerking tussen verschillende disciplines vormen het hart van de unieke Wageningen aanpak. 



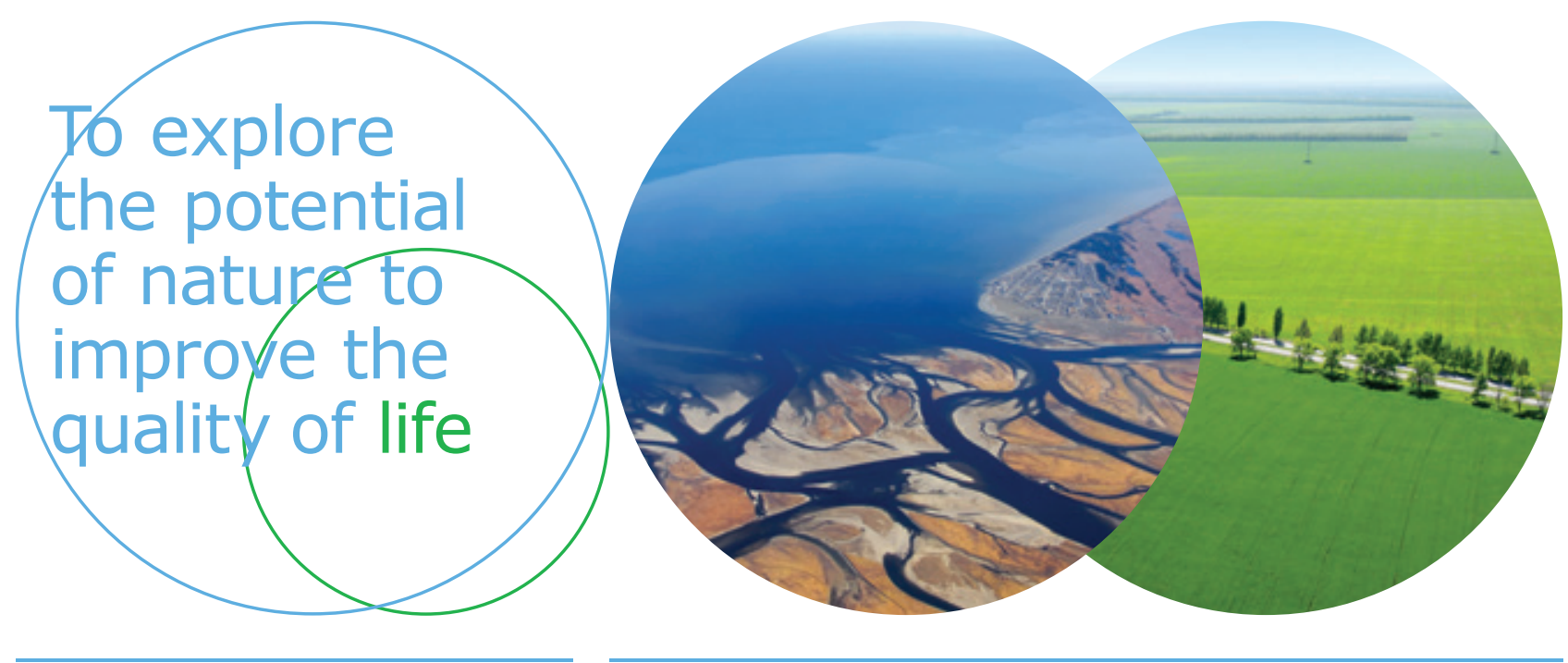

Wageningen Environmental Research Postbus 47

$6700 \mathrm{AB}$ Wageningen

T 317480700

www.wur.nl/environmental-research

Rapport 2941

ISSN 1566-7197
De missie van Wageningen University \& Research is 'To explore the potential of nature to improve the quality of life'. Binnen Wageningen University \& Research bundelen Wageningen University en gespecialiseerde onderzoeksinstituten van Stichting Wageningen Research hun krachten om bij te dragen aan de oplossing van belangrijke vragen in het domein van gezonde voeding en leefomgeving. Met ongeveer 30 vestigingen, 5.000 medewerkers en 10.000 studenten behoort Wageningen University \& Research wereldwijd tot de aansprekende kennisinstellingen binnen haar domein. De integrale benadering van de vraagstukken en de samenwerking tussen verschillende disciplines vormen het hart van de unieke Wageningen aanpak. 